\title{
U.S. Geological Survey-Department of the Interior Region 11, Alaska-2020 Annual Science Report
}

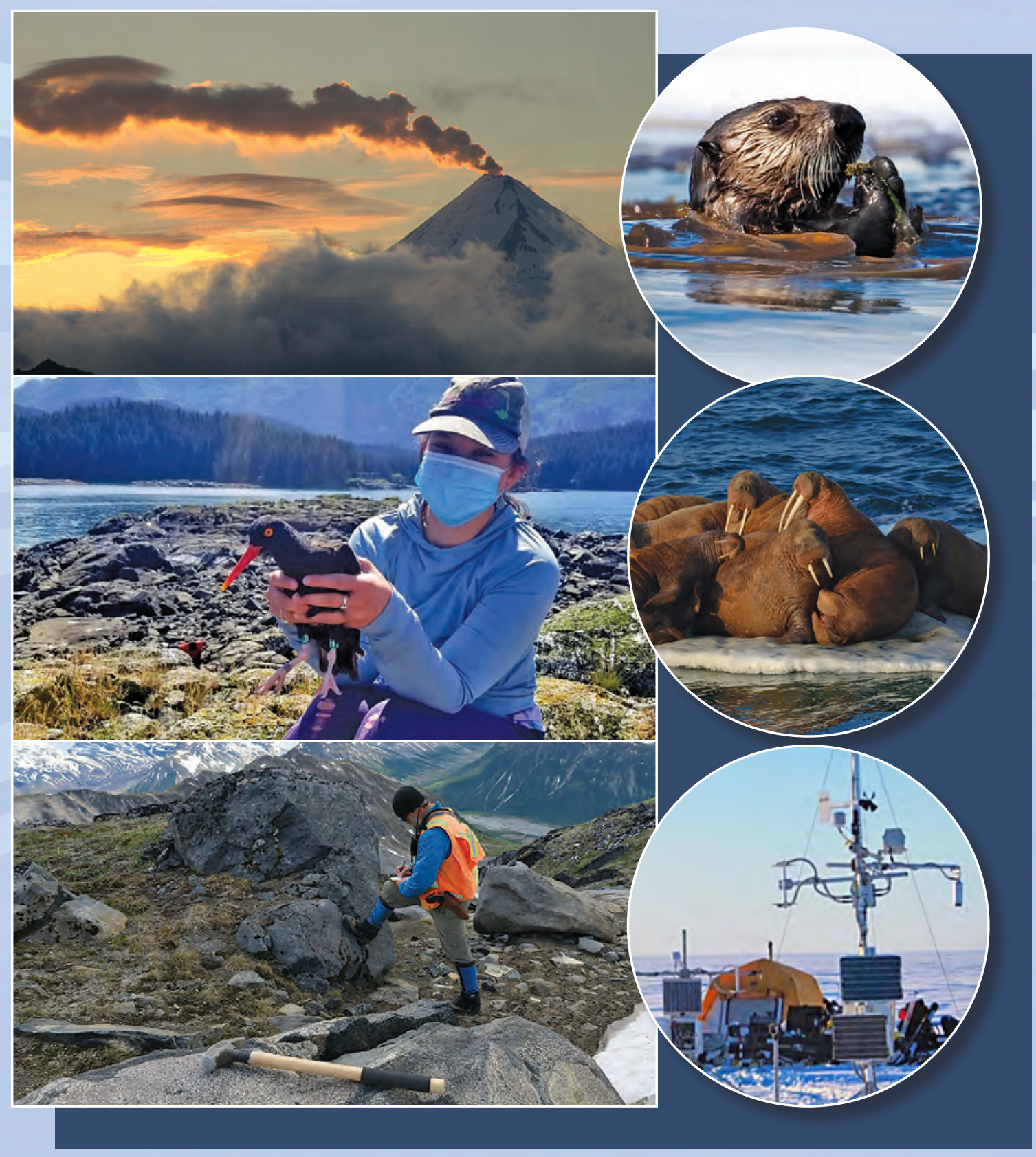

Open-File Report 2021-1010

U.S. Department of the Interior

U.S. Geological Survey 
Cover:

Top Left: Photograph of Shishaldin Volcano at sunset, Unimak Island, Alaska, taken by Cyrus Read, U.S. Geological Survey (USGS), August 20, 2009.

Top right: Photograph of sea otter in kelp, Alaska, by Benjamin Weitzman, USGS.

Middle left: Photograph of USGS biologist preparing to release a black oystercatcher in Alaska, taken by Brian Robinson, USGS, July 2020.

Middle right: Photograph of walruses resting on an ice floe in the Chuckchi Sea, northern Alaska, taken by USGS, June 3, 2020.

Bottom left: Photograph of USGS geologist collecting igneous rock samples in Lake Clark National Park, Alaska, taken by USGS.

Bottom right: Photograph of climate station maintenance near Teshekpuk Lake, northern Alaska, taken by Frank Urban, USGS. 


\section{U.S. Geological Survey-Department of the Interior Region 11, Alaska-2020 Annual Science Report}

Edited by Elizabeth M. Powers and Dee M. Williams

Open-File 2021-1010 


\section{U.S. Geological Survey, Reston, Virginia: 2021}

For more information on the USGS — the Federal source for science about the Earth, its natural and living resources, natural hazards, and the environment—visit https://www.usgs.gov or call 1-888-ASK-USGS.

For an overview of USGS information products, including maps, imagery, and publications, visit https://store.usgs.gov.

Any use of trade, firm, or product names is for descriptive purposes only and does not imply endorsement by the U.S. Government.

Although this information product, for the most part, is in the public domain, it also may contain copyrighted materials as noted in the text. Permission to reproduce copyrighted items must be secured from the copyright owner.

Suggested citation:

Powers, E.M., and Williams, D.M., eds., 2021, U.S. Geological Survey—Department of the Interior Region 11, Alaska —2020 annual science report: U.S. Geological Survey Open-File Report 2021-1010, 80 p., https://doi.org/10.3133/ ofr20211010.

ISSN 2331-1258 (online) 


\section{Director's Message}

Dear Stakeholders and Partners:

2020 has been an unusual and challenging year in almost every conceivable way. There have been many obstacles to navigate and overcome in every aspect of our lives, sometimes through sacrifice and discipline and other times through creativity and patience. This

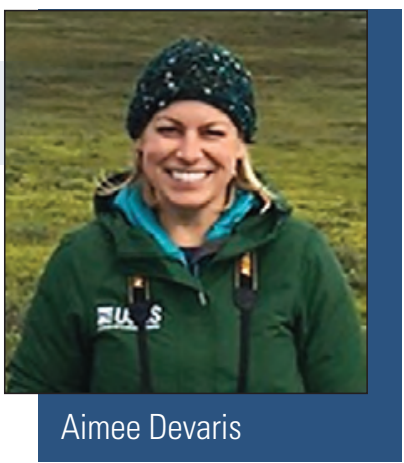
year has reinforced some core values for me-one is a profound admiration and appreciation for my colleagues in U.S. Geological Survey (USGS) and indeed across the science community here in Alaska and beyond, and another is a deep understanding of the importance of scientific integrity as a matter of critical importance in decision-making in policy related to public health, safety/security, and the environment.

Nearly all scientific field work within Region 11 (Alaska) was disrupted in 2020 because of the 2019 novel coronavirus disease (COVID-19) pandemic. USGS has several "mission essential functions" under the continuity of operations plans for the Federal government, and we planned very carefully to ensure that those activities could safely continue. We took a deliberate and proactive approach to meet the various health mandates associated with the State of Alaska and other borough and municipal jurisdictions to mitigate risks to our scientists and technicians as well as our Alaskan communities. Over the past several months, we managed to conduct remote field work to maintain streamgages across the State in preparation for the spring break-up on Alaska's rivers, deploy teams to respond to recent flood conditions, maintain and install new volcano monitoring systems in the eastern Aleutians and on Alaska Peninsula, and collect critical data to ensure continuity of long-term records important for climate monitoring.

We also found creative ways to respond to new challenges. In May 2020, local geologists identified a steep, unstable slope with the potential to become a massive tsunami-generating landslide in Barry Arm near Prince William Sound, east of Anchorage, Alaska. While working entirely remotely, USGS completed an initial analysis using satellite-based imagery showing that the slide was relatively stable. The State of Alaska, the National Oceanic and Atmospheric Administration, and the U.S. Forest Service cooperated to collect other key datasets, install monitoring equipment, and develop a strategy to warn mariners and nearby communities if the slope fails. A series of public meetings have been held and more are planned to provide information and assurance to the residents of this region. Despite the remote location of the potential landslide and the constraints related to the pandemic, these agencies have come together with efficiency and expertise to respond to a very challenging potential hazard scenario.

With most of our staff teleworking and spending far less time traveling or in the field, we had a very productive year in terms of data releases and publications. During fiscal year 2020, the Alaska Science Center delivered 76 data releases through its Trusted Data Repository. This is greater than a two-fold increase in yearly data releases and a fiscal year record for the Center. Additionally, the Alaska Science Center delivered more than 214 peer-reviewed publications, including USGS Series and manuscripts published through external journals, books, and monographs. Likewise, the Volcano Science Center completed 230 journal articles and 20 data releases. 
Ushering in a new decade, we made it a priority to initiate the planning for a new Arctic Science Strategy for 2021, reflecting the progress we have made in completing some foundational elements of our science portfolio and representing a new era in focus and clarity on our mission capabilities. This will dovetail with the new 5-year interagency Arctic Research Plan due to be published by the end of 2021.

Looking forward, the USGS remains committed to maintain a leadership role in Arctic science and technology by delivering accurate studies of relevant physical, geological, chemical, and biological resources or hazards, and by promoting integration of these activities through an increasingly holistic and service-oriented approach. We also are committed to ensuring inclusive and equitable workforce strategies and increasing participation in science for underrepresented groups in Alaska and the Arctic.

I'm pleased to share this Annual Report, on behalf of the USGS and U.S. Department of the Interior (DOI).

\section{Aimukthani}

Aimee M. Devaris

USGS DOI Region 11 Director 


\section{Contents}

Alaska Organizational Overview .............................................................................................

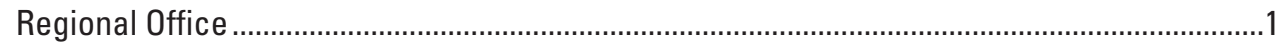

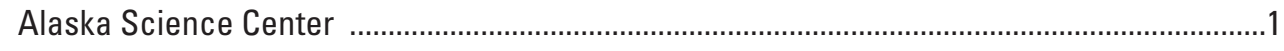

Volcano Science Center .........................................................................................................

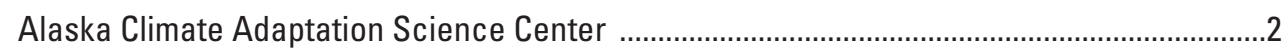

External Partners …...........................................................................................................

Annual Spotlight-COVID-19 Effects on Alaska Region .........................................................

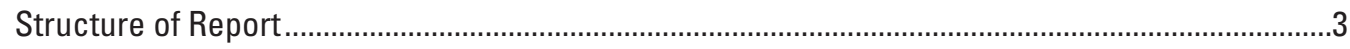

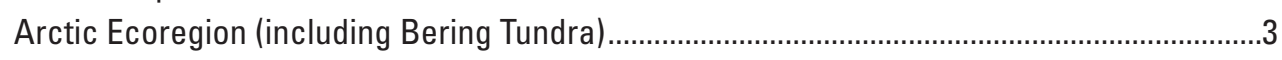

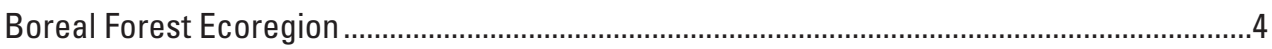

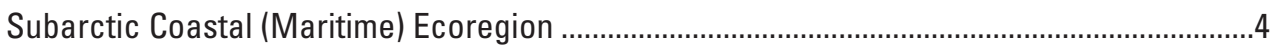

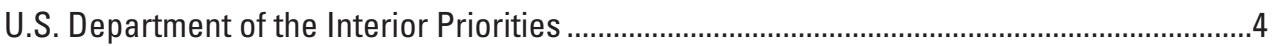

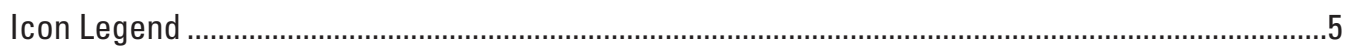

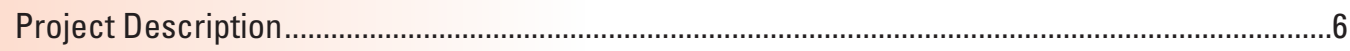

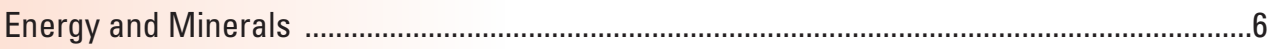

Energy Resources ......................................................................................................

Alaska Petroleum Systems....................................................................................

Gas Hydrate Resource Characterization ....................................................................

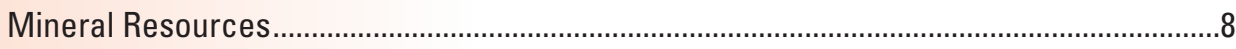

Maintenance of Alaska Geologic Map and Mineral Deposit

Geographic Information System Prospectivity Analysis for Critical Minerals in Ore-Forming Systems in Alaska..........................................................................

Improving Understanding of Critical Mineral Potential in the Alaska Outer Continental Shelf ...............................................................................................

Petrogenesis and Mineralization of the Darby and Kachauik Plutons, Seward

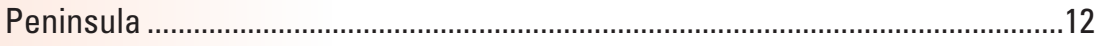

Mineral Resource Databases and Information Analysis ..............................................13

Tectonic and Metallogenic Evolution of the Broader Yukon-Tanana Upland..................13

Light Detection and Ranging (Lidar) ............................................................................15

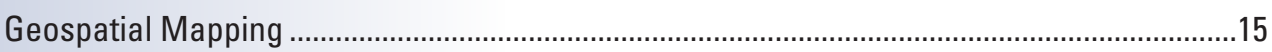

Alaska IfSAR Radar Elevation Data Acquisition Program ..............................................16

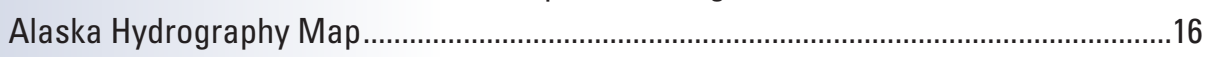

Landsat 9 Analysis Ready Data .............................................................................17

Arctic Research Policy Act (ARPA) Boundary Maps ......................................................18 


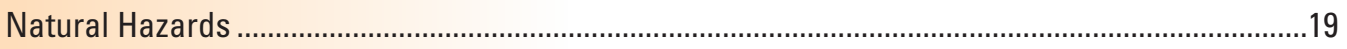

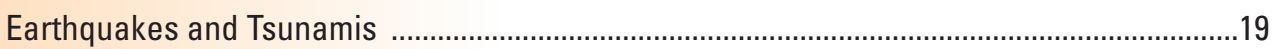

Alaska Earthquake Hazards ...................................................................................19

Barry Arm Landslide Motion and Tsunami Potential ...................................................20

Offshore Crustal Imaging of the Queen Charlotte Fault System to Characterize Deformation and Seismic Hazard in Southeastern Alaska .................................21

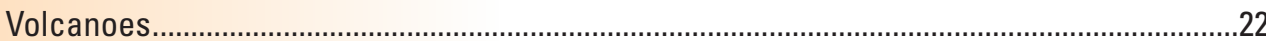

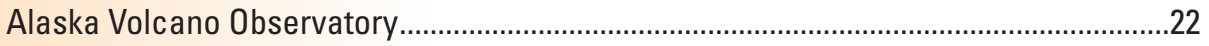

Analog-to-Digital Conversion of Monitoring Sites in Alaska............................................24

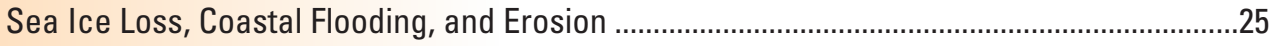

Alaska Coastal Processes and Hazards ......................................................................25

Building an Operational System to Forecast Potential Flood Hazards in Unalakleet,

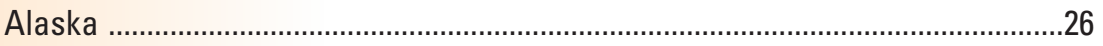

Wave and Hydrodynamic Observations and Modeling in the Nearshore Beaufort

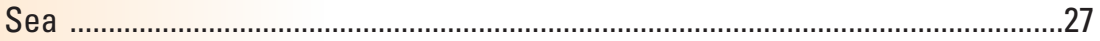

National Assessment of Shoreline Change on the Coast of Alaska ..............................28

Wildfire

Ecosystems on the Edge-Changing Fire Regimes and Fire Behavior Impact on the Ecology and Management of Boreal and Tundra Systems ..................................29

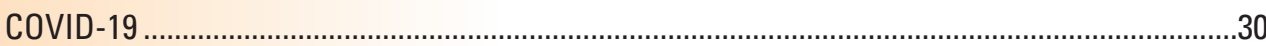

Survey —COVID-19 Effects on Alaska Region …………..............................................30

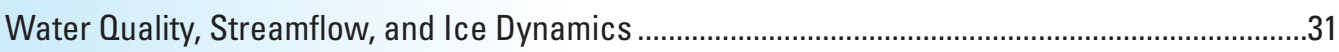

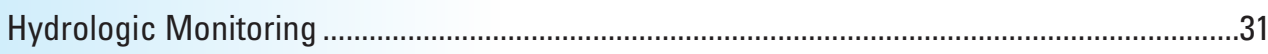

Streamflow and Groundwater Monitoring ……….......................................................

Continuous Monitoring and Baseline Assessment of Water Quality of Transboundary Alaskan Rivers ...........................................................................32

Developing Remote Sensing Methods to Measure Streamflow in Alaskan Rivers ......33

Alaska Streambed Scour Monitoring and Modeling . .34

Indigenous Observation Network 2.0-Impacts of Environmental Change on the Yukon and Kuskokwim Watersheds ...................................................................35

Quantifying Groundwater and Aufeis and Their Contribution to Surface-Water Availability and Habitat in the Arctic National Wildlife Refuge, Alaska...............36

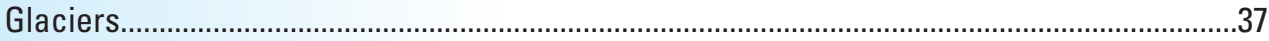

U.S. Geological Survey Benchmark Glacier Mass Balance Project...............................37

Wildfire Aerosols Determine Types of Past Burned Vegetation Archived in the

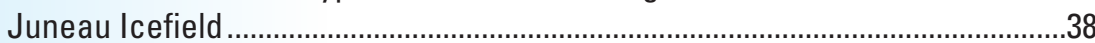

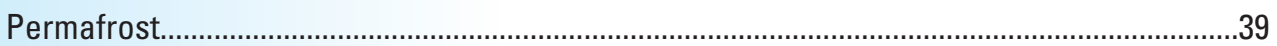

Arctic Biogeochemical Response to Permafrost Thaw (ABRUPT) ...................................39

Permafrost Mapping and Land-Cover Change ...............................................................40

Hydrologic Change in Permafrost Systems...............................................................

Mercury and Carbon Dynamics in the Environment....................................................42

U.S. Geological Survey Climate and Permafrost Observing Network ............................43

Strategic Needs of Water in the Yukon (SNOWY) .........................................................4 


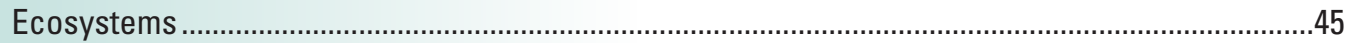

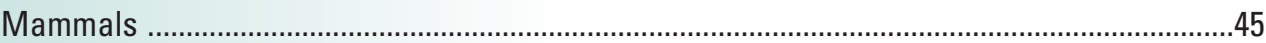

Polar Bear Distribution, Population Dynamics, Health, and Energetics Research ........45

Pacific Walrus Research ............................................................................................4

Nearshore Marine Ecosystem Research ........................................................................48

Ecology of Terrestrial Vertebrates (Caribou, Moose, Sheep, Wolves, Bears) in

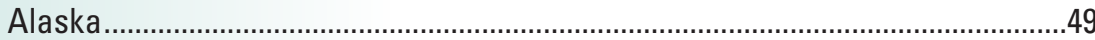

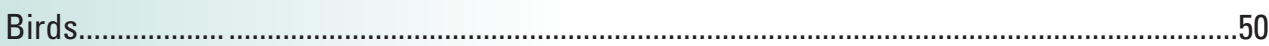

Seabirds and Forage Fish Ecology Program ..........................................................50

Role of Gulls in Alaska in the Dissemination of Antimicrobial-Resistant E. coli .............51

Population Ecology of Waterfowl and Loons ..........................................................52

Population Ecology and Habitats of Alaska Landbirds...................................................53

Population Status and Ecology of North Pacific Shorebirds........................................54

Contaminant Exposure, Bioaccumulation, and Ecological Effects in Aquatic and

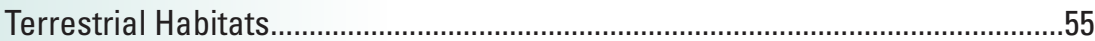

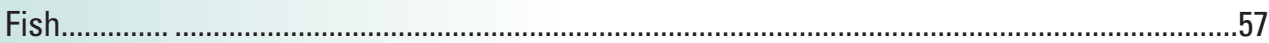

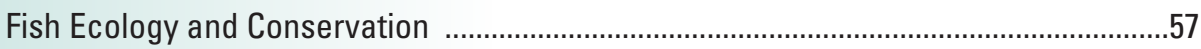

Heat Stress in Alaska's Pacific Salmon .....................................................................58

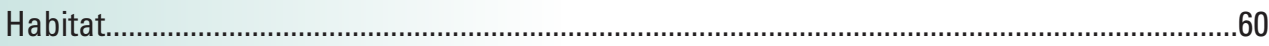

Beavers Impacting Tundra Ecosystems-Quantifying Effects on Hydrology, Permafrost, Water Quality, and Fish Habitat in Noatak Wild and Scenic River Basin, Alaska ..............................................................................................

Land Cover Classification and Change Detection on the Kenai Peninsula, 1973-2017........61

Habitat Dynamics—Using Satellite Remote-Sensing in Landscape-Scale Wildlife and Ecological Process Studies .......................................................................62

Rapid Ecosystem Changes in Tundra Biomes-Implications for Landscapes and

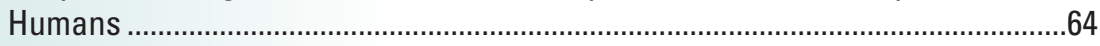

Remote Sensing Ecology Project, LandCarbon Alaska ................................................65

Nutrient and Contaminant Metal Fluxes to Alaskan Coastal Surface Waters ...............66

Early Warning Vital Signs in Arctic Network Parklands ...............................................67

Assessing Baseline Contaminants in the 1002 Areas of the Arctic National Wildlife

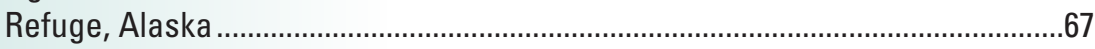

Cross-Cutting Programs .................................................................................................68

EarthMAP Use Case Development in Alaska...............................................................68

U.S. Geological Survey Changing Arctic Ecosystems ..................................................69

Collaboration with the Interagency Arctic Research Policy Committee..........................70

U.S. Geological Survey Emerging Wildlife Disease ........................................................71

U.S. Geological Survey and National Park Service Natural Resources Preservation Program ...................................................................................................

U.S. Geological Survey and U.S. Fish and Wildlife Service Science Support and Quick Response Program.......................................................................................

Alaska Native Science and Engineering Program Partnership ......................................74

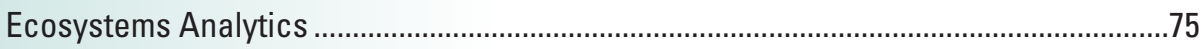

Looking Forward, Looking Back-Building Resilience Today..........................................76

Developing and Applying Molecular Tools to Natural Resource Problems in Alaska........77

Land-Sea Linkages in the Arctic_Climate History and Past Environmental Change .......78 
This page intentionally left blank. 


\title{
U.S. Geological Survey-Department of the Interior Region 11, Alaska-2020 Annual Science Report
}

\author{
Edited by Elizabeth M. Powers and Dee M. Williams
}

\section{Alaska Organizational Overview}

U.S. Geological Survey (USGS) Mission: The USGS national mission is to monitor, analyze, and predict current and evolving dynamics of complex human and natural Earthsystem interactions and to deliver actionable information at scales and timeframes relevant to decision-makers. Consistent with the national mission, the USGS in Alaska provides timely and objective scientific information to help address issues and inform management decisions across five inter-connected themes:

- Energy and Minerals;

- Geospatial Mapping;

- Natural Hazards;

- Water Quality, Streamflow, and Ice Dynamics; and

- Ecosystems.

The USGS in Alaska consists of approximately 350 scientists and support staff working in three Alaska-based science centers, a Cooperative Research Unit, and USGS centers outside Alaska, with a combined annual science budget of about $\$ 60$ million. In the last 5 years, USGS research in Alaska has produced many scientific benefits resulting from more than 1,100 publications. Publications relevant to Alaska can be conveniently searched by keyword through the USGS Publications Warehouse at https://pubs.er.usgs.gov/search?q=Alaska.

\section{Regional Office}

The Office of the Alaska Regional Director provides strategic leadership for the region's science programs while facilitating growth of USGS science capacity centering on Arctic and Subarctic systems. The office maintains relations with other Federal and State agencies, Tribes, the international community, and the academic community, advancing the goals and objectives of the U.S. Department of the Interior (DOI) and the Administration and representing a single interface point for the entire breadth of USGS science and its capabilities. The regional office is responsible for gathering, synthesizing, and delivering scientific information that is timely, relevant, and impartial concerning Alaska's geology, geography, hydrology, diverse physical and biological resources, and natural hazards.
The Alaska Regional Office maintains a distinctive organizational status within USGS by virtue of several key factors:

1. Alaska's size, extensive coastline, geographic separation, Arctic and circumpolar nexus, and complex tectonic history afford it a unique geology and geography compared to the rest of the Nation;

2. The Federal government manages about 65 percent of Alaska as public lands, including numerous national forests, national parks, and national wildlife refuges;

3. Alaska Native subsistence activities and legal protections shape the planning and conduct of scientific research throughout the State; and

4. The USGS Alaska Science Center (ASC) currently operates one of the largest and most scientifically integrated centers within USGS, and a large volume of Alaskan and Arctic research activities also are conducted by staff from centers outside the State, thus making the Alaska Region a highly dynamic and resourceful area for USGS activities.

The Alaska Regional Office provides management and strategic coordination with the ASC, the Volcano Science Center (VSC), the Alaska Climate Adaptation Science Center (AKCASC), USGS scientists from other regions, and external partners operating in Alaska. Current Alaska Regional personnel include the Regional Director (Aimee Devaris), the Deputy Regional Director (Dr. Dee Williams), Chief of Staff/ Regional Management Officer (Durelle Smith), Senior Science Advisor (Thomas Murray), Science Coordinator (Dr. Elizabeth Powers), Safety Manager (Daniel Morgan), and Budget Analyst (Marnelli Cordero). More information about the Alaska Region is available at https://www.usgs.gov/science/regions/ alaska-region.

\section{Alaska Science Center}

The ASC, led by Dr. Christian Zimmerman, is composed of about 150 science personnel representing the full suite of disciplines at USGS. Research and activities in support of all the USGS Mission Areas are managed collectively with a vision to achieve an integrated landscape-level understanding of the highly diverse and complex ecosystems of Alaska. Its current science priorities are mineral and energy resources, public safety, and addressing priority information needs for land and water stewardship. The ASC delivered more than 
410 science information products in Fiscal Year (FY) 2020, including 189 journal articles, 25 USGS series reports, 14 book chapters, 76 data releases, and 1 software release. More information about specific research conducted in Alaska is available in this volume and on the ASC web portal at https:// www.usgs.gov/centers/asc.

\section{Volcano Science Center}

The VSC, long led by Thomas Murray until his transition to the Regional Office in November, is based in the Alaska Region, and manages the five U.S. volcano observatories and about 200 employees on the West Coast and in Hawaii. The VSC encompasses the (1) Alaska Volcano Observatory (AVO) in Anchorage; (2) Cascades Volcano Observatory and (3) Yellowstone Volcano Observatory in Vancouver, Washington; (4) Hawaiian Volcano Observatory in Hilo, Hawaii; (5) and California Volcano Observatory in Moffett, California; as well as the internationally scoped Volcano Disaster Assistance Program. Their common mission is to enhance public safety and minimize social and economic disruption from eruptions through delivery of effective forecasts, warnings, and information of volcano hazards based on scientific understanding of volcanic processes. The VSC delivered more than 460 science information products in FY2020, including 230 journal articles and 20 data releases. Follow news from the AVO at https:// www.avo.alaska.edu/.

\section{Alaska Climate Adaptation Science Center}

The AKCASC, led by Dr. Stephen Gray, is one of eight regional centers that provide managers with the tools and information they need to develop and execute management strategies that address the impacts of the climate on natural and cultural resources. The Center is hosted by the University of Alaska Fairbanks but is physically housed within the USGS campus at Alaska Pacific University. Various program partners provide expertise in climate science, ecology, environmental impact assessments, modeling, and advanced information technology. The year 2020 marked the start of a suite of efforts aimed at understanding the impacts of climate change on salmon and aquatic habitats. In cooperation with the Bureau of Indian Affairs and Aleutian Pribilof Islands Association, the AKCASC conducted a series of workshops and public engagement events aimed at building climate resilience in Alaska Native communities. The AKCASC also kicked off a novel cross-regional collaboration with the Pacific Islands Climate Adaptation Science Center that will promote joint research in "Icefield to Ocean" and "Ridge to Reef" systems, while also providing opportunities for undergraduate and graduate student exchange. The AKCASC, with about 30 staff, yielded roughly 100 information products in FY2020, including 33 publications and about 65 reports to stakeholders. More information is available at https://casc.alaska.edu/.

\section{External Partners}

To meet the Nation's most pressing science needs and to deliver timely and relevant information, USGS scientists routinely work with other Federal, State, and local government agencies; Tribal nations; academic institutions; and nongovernmental and private organizations. For the purposes of this report, we define a partner as any entity that actively works with USGS to co-fund or co-produce scientific research activities. External partners include more than 20 Federal agencies, 25 State agencies, five Alaska Native Organizations, 20 non-governmental organizations, 10 industry partners, and more than 50 academic institutions. USGS Regional Managers collaborate actively with DOI Alaska Bureaus and State and regional groups, especially through the Alaska Cooperative Planning Group, the Interagency Arctic Research Policy Committee, the North Slope Science Initiative, Arctic Council Working Groups, and numerous bilateral interagency agreements with the DOI bureaus of the U.S. Fish and Wildlife Service (FWS), National Park Service (NPS), Bureau of Ocean Energy Management (BOEM), and Bureau of Land Management (BLM).

One formal partnership worth an explicit mention is the Alaska Cooperative Fish and Wildlife Research Unit hosted at the University of Alaska Fairbanks campus. This unit is part of a nationwide program to foster college-level research and graduate student training in support of science-based management of fish and wildlife and their habitats. The Alaska Unit exists by cooperative agreement between the USGS, Alaska Department of Fish and Game (ADF\&G), University of Alaska Fairbanks, FWS, and the Wildlife Management Institute. The unit mission is aimed at understanding the ecology of Alaska fish and wildlife, evaluating impacts of land use and development on these resources, and relating effects of social and economic needs to production and harvest of natural populations. The Alaska Unit is led by Dr. Jeffrey Falke, Assistant Professor of Fisheries, and the Alaska Unit website address is https://www.akcfwru.uaf.edu/.

\section{Annual Spotlight-COVID-19 Effects on Alaska Region}

COVID-19 has become the most dominant news event and scientific phenomenon of 2020. The sudden emergence and rapid spread of the novel coronavirus into a global pandemic has continually shaped this memorable year into one of tumultuous change.

Throughout the pandemic, the whole of USGS has been united in accomplishing our mission as best we can in these complex times. However, a pivot has been forced upon all aspects of science operations as each Science Center re-evaluated which activities should be paused, altered, or continued with modification while maintaining a focus on health and safety as the primary consideration. 
Working within multiple layers of policy guidance emanating from the Centers for Disease Control, Office of Management and Budget, DOI, and the State of Alaska Department of Health and Social Services, the USGS in Alaska has been continually implementing new internal processes to limit employee exposure to risk while meeting current fieldwork challenges associated with COVID-19. Since March, the Region has worked with Center Directors to restrict field work and travel to conduct only mission-critical functions. Additionally, as confirmed local cases of the virus increased and the Municipality of Anchorage issued emergency stay-at-home orders, workforce continuity plans necessitated a major shift to implement widespread telework arrangements and social distancing protocols for all staff, thus limiting routine access to office and lab facilities beginning in March.

Through it all, the vital question has continually arisen: What are the variety of effects and most substantive impacts from COVID-19 on USGS activities and personnel specific to the work of the Alaska Region, and what can be done to mitigate them? Many fieldwork operations were suspended, deferred, or cancelled outright. As the summer fieldwork season concluded, the Alaska Regional Office determined to gather more information on the wide variety of professional and personal effects from the pandemic by developing and circulating a survey instrument open to all regional employees from August 12 to 21. Data collected from the voluntary and anonymous survey were then aggregated for analysis and yielded many summary findings. A brief list of initial reported effects can be accessed within the Survey project description available in section, "Natural Hazards: Covid 19." A second survey is planned in the second quarter of 2021 to obtain additional input over a longer time horizon that will allow for more thorough analysis.

Respondents generally tended to credit Center and Regional management for responding well to a very difficult situation, with clear appreciation expressed for the emphasis on health and safety while allowing critical fieldwork to continue. People also generally expressed gratitude for relatively smooth communication patterns that keep staff well informed as plans and policies changed. It also is both unfortunate and relevant that a new surge of infections arose in Alaska and Anchorage in the fall, extending the need for school closures and strict social precautions just as these survey results were collected.

\section{Structure of Report}

The research highlighted in this annual report is organized primarily by the five major topical areas (energy and minerals; geospatial mapping; natural hazards; water quality, streamflow, and ice dynamics; and ecosystems). The topical areas are then subdivided into relevant subsections. However, each project description also could be sorted into other categories of reader interest, such as geographic location, or association with established DOI research priorities. To facilitate this type of search and discovery, this report uses various icons, which are embedded immediately below the title of each project description. Different icons are used to represent the five different categories of topics, four different geographic locations, and five different established DOI priorities. All 14 icons are illustrated in a legend at the conclusion of this section.

This report uses broad ecoregions as a convenient means to establish categories of geographic location. An ecoregion is an ecologically and geographically defined area that covers relatively large areas of land or water and contains distinct assemblages of natural communities and species. Within each ecoregion, there exists substantial, but not absolute spatial correlation among the characteristic assemblages. The three broad Alaska ecoregions include (1) Arctic, (2) Boreal Forest, and (3) Subarctic Coastal (Maritime). A fourth icon is used to represent work that generally spans across the entire State of Alaska.

\section{Arctic Ecoregion (including Bering Tundra)}

The Arctic ecoregion of Alaska encompasses the area north of the Arctic Circle and consists of the flat and treeless coastal plains and the rolling foothills and rugged peaks of the Brooks Range. The Arctic Research Policy Act of 1984 (Public Law 98-373, amended as Public Law 101-609) expands the definition to include "the territory north and west of the Porcupine, Yukon, and Kuskokwim Rivers (including North Slope and Northwest hydrologic zones), and all contiguous seas (including the Bering, Beaufort, Chukchi, and Arctic Seas)." The climate of the ecoregion primarily is cold and dry, where freezing temperatures dominate most of the year. The Arctic Ecoregion also includes the Bristol Bay region, Bering Sea islands, and parts of the Seward Peninsula and Yukon-Kuskokwim Delta (YKD). The climate in the area of the Arctic is transitional between maritime and continental in the Bristol Bay area and shifts to a moist polar climate to the north. 


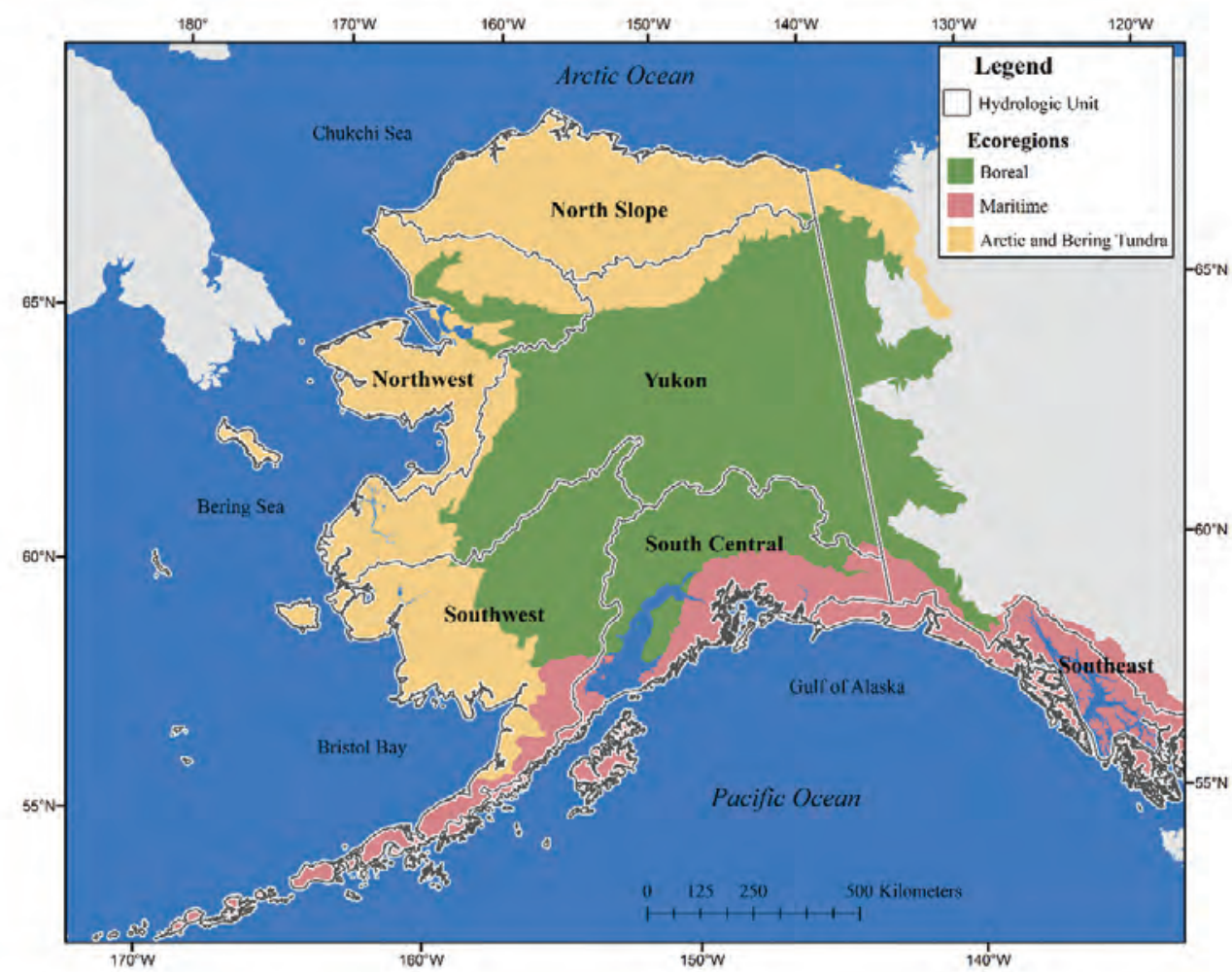

U.S. Geological Survey map showing the three major ecoregions (arctic, boreal, maritime) and six major hydrologic zones of Alaska (Southeast, South Central, Southwest, Yukon, Northwest, and North Slope). Source: Figure 1, Stackpoole, S.M., and others, Inland waters and their role in the carbon cycle of Alaska: Ecological Applications, 2017. 27, no. 5, p. 1403-1420, https:// doi.org/10.1002/eap.1552.

\section{Boreal Forest Ecoregion}

The Boreal Forest ecoregion encompasses interior Alaska, stretching from the southern side of the Brooks Range in the north and to the Alaska Range in the south. This region covers a wide geographic area and thus has considerable variation in temperature and precipitation, yet the climate is considered continental with short, warm summers, and long, cold winters.

\section{Subarctic Coastal (Maritime) Ecoregion}

This is the most diverse ecoregion in Alaska, consisting of subarctic coastal regions stretching from Southeast Alaska to the tip of the Aleutian Island chain. Variable landscapes include fjords, beaches, rocky intertidal zones, kelp forests, underwater seamounts, and a sedimentary seafloor. Southeast Alaska is characterized by its maritime climate, temperate rainforests, abundant islands, and long fjords. The Aleutian Islands are a chain of volcanic islands covered in rugged mountain peaks with carved fjords, high cliffs, rocky and wave-battered beaches, and small dune fields. This part of the region has a cool maritime climate but varies greatly in terms of precipitation amounts, although high winds and intense ocean storms are common across the region.

\section{U.S. Department of the Interior Priorities}

This report links each USGS program/project description with established DOI priorities and goals. In 2020, there were five DOI priorities and goals that apply most directly to the conduct of science in Alaska, as illustrated by the distinct icons that appear in the legend at the end of the following section. 


\section{Icon Legend}

\section{Topical Areas:}

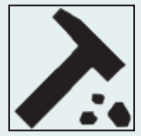

Energy and Minerals

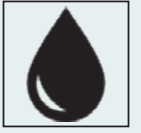

Water Quality, Streamflow, and Ice Dynamics

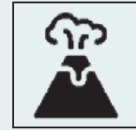

Natural Hazards

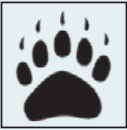

Alaska Mapping
Wildlife, Fish, and Habitat

\section{Ecoregions:}

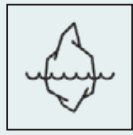

Arctic

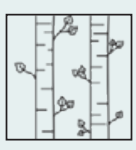

Boreal Forest

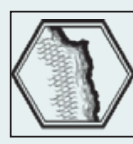

Subarctic Coastal

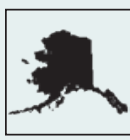

Statewide

\section{Alaska U.S. Department of the Interior Priorities:}

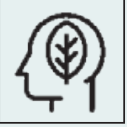

Create a conservation stewardship legacy

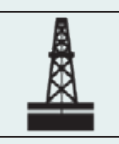

Sustainably develop our energy and natural resources

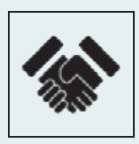

Restore trust with local communities

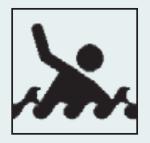

Protect our people and the border

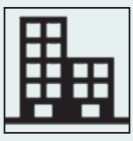

Modernize our infrastructure

Note: All maps, illustrations, and photographs in the report have a USGS source that is in the public domain, unless otherwise noted. 


\section{Project Descriptions}

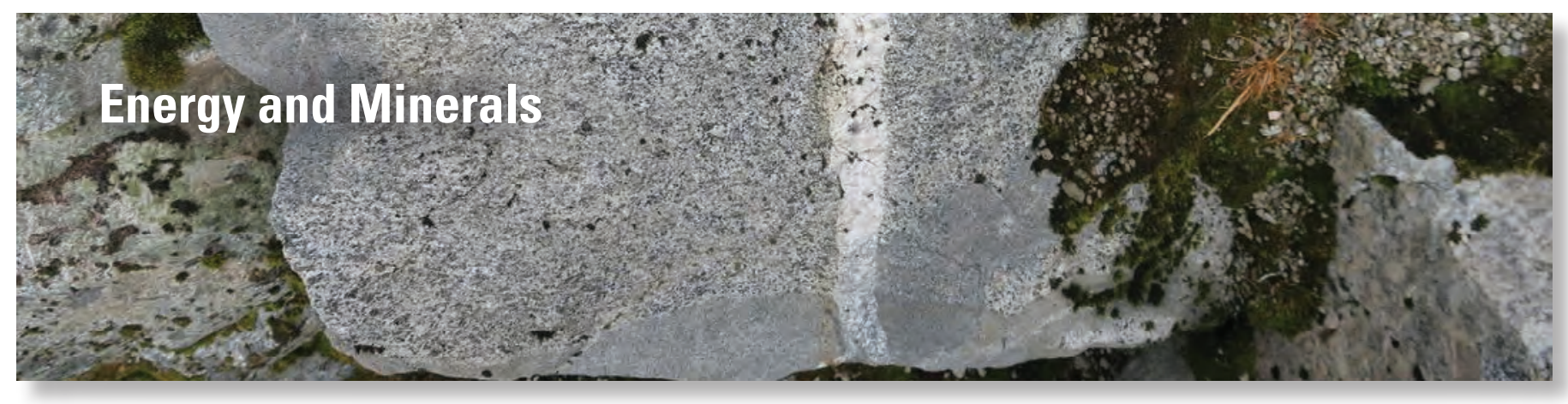

\section{Energy Resources}

\section{Alaska Petroleum Systems}

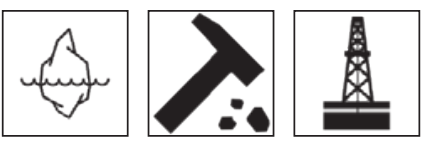

Since 2017, the USGS Alaska Petroleum Systems project has concentrated on complying with DOI Secretarial Order 3352, which directs the USGS to update a series of assessments across the entire Alaska North Slope. The project has three main objectives: (1) conduct research that increases our understanding of Alaska petroleum systems; (2) conduct assessments of undiscovered oil and gas resources; and (3) deliver energy-resource information to land and resource managers, policy makers, and the public. Fundamental research methods - such as regional sequence stratigraphic and structural framework, distribution and quality of source rocks, geochronologic and thermochronologic history of critical regions - are essential because Alaska remains an underexplored energy frontier. A robust petroleum-systems framework is the key to understanding regional petroleum potential, completing our mission-critical work (assessments of undiscovered petroleum resources), and responding quickly to information requests regarding new and emerging oil and gas activities.

\section{Contact}

David Houseknecht, USGS Eastern Energy Resources Science Center, Reston, Virginia, dhouse@usgs.gov, (703)648-6466

\section{Project Link}

https://www.usgs.gov/energy-and-minerals/energy-resources-program/science/alaskapetroleum-systems

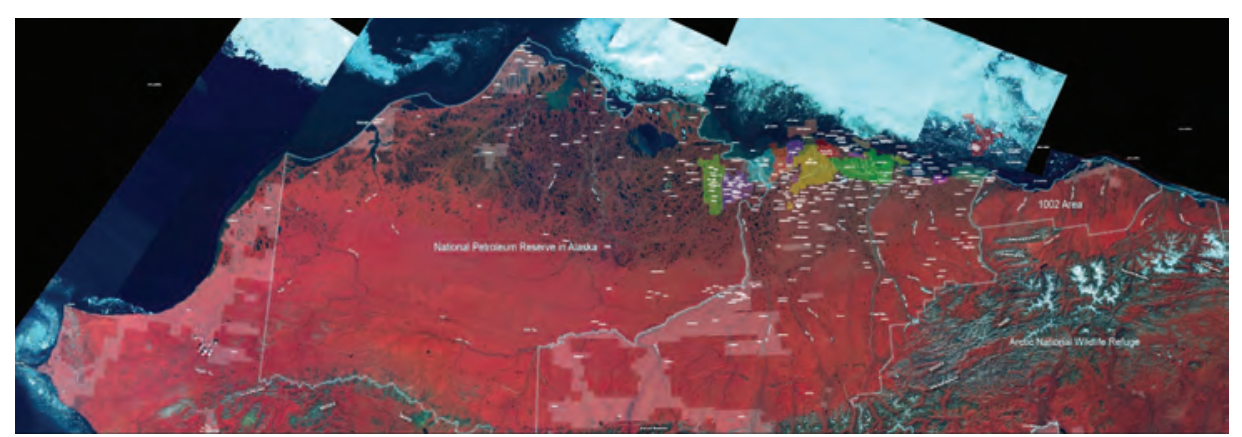

False-color composite Landsat image of northern Alaska showing boundaries of the National Petroleum Reserve in Alaska (NPR-A) and the Arctic National Wildlife Refuge (ANWR; including "1002 Area"), Native lands (transparent white polygons, existing and proposed oil fields (colored polygons), and exploration wells (white labels). Project work extends across the full 650-mile width of the North Slope and adjacent offshore. Image provided by Chris Garrity, U.S. Geological Survey. 


\section{Recent Publications}

Houseknecht, D.W., Bird, K.J., and Garrity, C.P., 2020, Geology and assessment of undiscovered oil and gas resources of the Amerasia Basin Province, 2008, chap. BB of Moore, T.E., and Gautier, D.L., eds., The 2008 circum-Arctic resource appraisal: U.S. Geological Survey Professional Paper 1824, 33 p., https://doi.org/10.3133/pp1824BB.

Houseknecht, D.W., Whidden, K.J., Connors, C.D., Lease, R.O., Schenk, C.J., Mercier, T.J., Rouse, W.A., Botterell, P.J., Smith, R.A., Sanders, M.M., Craddock, W.H., DeVera, C.A., Garrity, C.P., Buursink, M.L., Karacan, C.O., Heller, S.J., Moore, T.E., Dumoulin, J.A., Tennyson, M.E., French, K.L., Woodall, C.A., Drake, R.M., II, Marra, K.R., Finn, T.M., Kinney, S.A., and Shorten, C.M., 2020, Assessment of undiscovered oil and gas resources in the central North Slope of Alaska, 2020: U.S. Geological Survey Fact Sheet 2020-3001, 4 p., https://doi.org/10.3133/fs20203001.

Rouse, W.A., Whidden, K.J., Dumoulin, J.A., and Houseknecht, D.W., 2020, Surface to subsurface correlation of the MiddleUpper Triassic Shublik Formation within a revised sequence stratigraphic framework: Interpretation, v. 8, p. SJ1-SJ16, https://doi.org/10.1190/INT-2019-0195.1.

Shah, A.K., Phillips, J.D., Lewis, K.A., Stanley, R.S., Haeussler, P.J., and Potter, C.J., 2020, Three-dimensional shape and structure of the Susitna basin, south-central Alaska, from geophysical data: Geosphere, v. 16, p. 969-990,

https://doi.org/10.1130/GES02165.1.

\section{Gas Hydrate Resource Characterization}

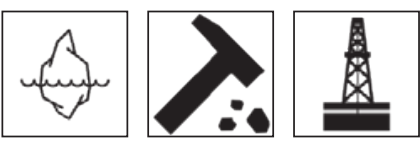

Gas hydrates are naturally occurring crystalline solids that form from water and gas occurring in permafrost regions and in marine sediments. Gas hydrates contain large amounts of methane and have the potential to become an energy resource. This effort addresses critical issues associated with production of gas hydrates, and contributes to our understanding of the geologic nature of the gas hydrate accumulations. It also helps develop plans for the extended gas hydrate production testing program in northern Alaska in order to assess the technology that will be required to safely produce this potentially important unconventional energy resource. The goal of this project is to conduct a long-term scientific reservoir response test using depressurization production technology. These activities will provide an initial assessment of the potential to successfully produce gas hydrate resources in similar settings throughout the U.S. and the world.

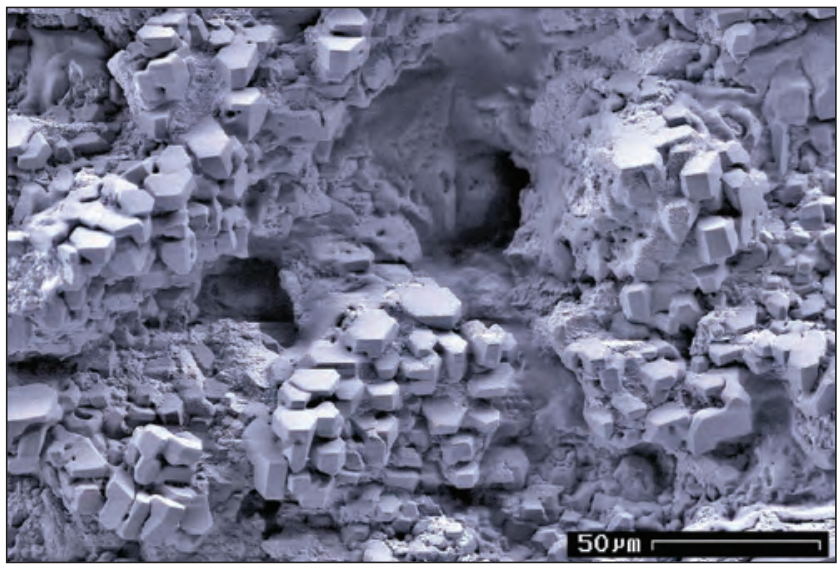

Scanning electron microscope image of gas hydrate crystals in a sediment sample. Scale is 50 micrometers $(\mu \mathrm{m})$ or approximately 0.002 inches. Photograph by Woods Hole Coastal and Marine Science Center. Public domain.

\begin{tabular}{ccc}
\hline Time frame & Budget & \multicolumn{1}{c}{ Project partners } \\
\hline $2018-23$ & $\$ 500,000-\$ 1,000,000$ & $\begin{array}{l}\text { U.S. Department of Energy, } \$ 230,700 ; \text { Alaska Department of Natural Resources (SOA-DNR); the } \\
\text { National Institute of Advanced Industrial Science and Technology (AIST; Japan); and the Japan } \\
\text { Oil, Gas and Metals National Corporation (JOGMEC; Japan) }\end{array}$ \\
\hline
\end{tabular}

\section{Contact}

Tim Collett, Central Energy Resources Science Center, Denver, Colorado, tcollett@usgs.gov, (720) 936-2372 Recent Publications

Boswell, R., Hancock, S., Yamamoto, K., Collett, T.S., Pratap, M., and Lee, S.-R., 2020, Natural gas hydrates—Status of potential as an energy resource, chap. 6 of Letcher, T.M., ed., Future energy ( $3 \mathrm{~d}$ ed.): Amsterdam, The Netherlands, Elsevier, p. 111-131. 
Collett, T.S., Lewis, K.A., Zyrianova, M.V., Haines, S.S., Schenk, C.J., Mercier, T.J., Brownfield, M.E., Gaswirth, S.B., Marra, K.R., Leathers-Miller, H.M., Pitman, J.K., Tennyson, M.E., Woodall, C.A., and Houseknecht, D.W., 2019, Assessment of undiscovered gas hydrate resources in the North Slope of Alaska, 2018: U.S. Geological Survey Fact Sheet 2019-3037, 4 p., https://doi.org/10.3133/fs20193037.

Collett, T., Okinaka, N., Wakatsuki, M., Boswell, R., Marsteller, S., Minge, D., Crumley, S., Itter, D., and Hunter, R., 2020, Design and operations of the Hydrate-01 Stratigraphic Test Well, Alaska North Slope: Proceedings of the 10th International Conference on Gas Hydrates, Singapore, June 21-26, 2021, 8 p. https:/www.netl.doe.gov/sites/default/files/2020-08/

Collett-et-al-Design-and-Operations.pdf

\section{Program Websites}

https://www.usgs.gov/centers/cersc/science/gas-hydrates?qt-science_center_objects=0\#qt-science_center_objects https://www.usgs.gov/centers/cersc/science/alaska-north-slope-2018-hydrate-01-stratigraphic-test-well?qt-science_center_ objects=0\#qt-science_center_objects

\section{Mineral Resources}

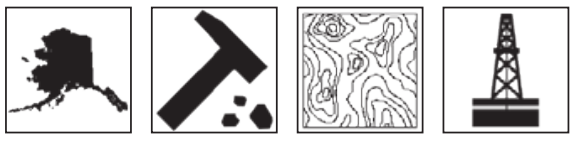

\section{Maintenance of Alaska Geologic Map and Mineral Deposit Databases}

The USGS collects data on the geology and mineral resources in Alaska and maintains this information in the Alaska Geologic Map and Mineral Deposit Databases. The USGS tracks and updates the (1) Alaska Geologic Map and (2) Alaska Resource Data File (ARDF).

\section{Alaska Geologic Map}

The Alaska geologic mapping project entails the maintenance and updating of the Alaska geologic map database created in 2015, incorporating newly available data and releasing these new data in episodic updates. The 2015 compilation involved creating text and spatial databases of available information and data. The dataset was then integrated statewide to produce, in addition to the new State map, several other derivative maps. As a digital database, it is a valuable analytical tool that can continually be updated. The project also works to integrate the Alaska data with datasets covering parts of Canada, Russia, and the conterminous United States. Mineral and energy resource assessments drive demand for the geologic map, but the map (and associated spatial and attribute datasets behind it) have tremendous potential for use in addressing regional environmental issues.

\section{ARDF}

The ARDF is a mission-critical database of mines, prospects, and mineral occurrences in the State of Alaska that is continually updated as new information becomes available. The project (1) provides complete, up-to-date, and user-friendly and user-accessible information on metallic and selected non-metallic mineral occurrences in Alaska; (2) tracks mineral industry activity in the State; and (3) systematically releases updated records on the Internet. The information collected and maintained by the project is valuable for mineral resource assessments, mineral deposit modeling, and mineral environmental studies, as well as land-use decisions.

\begin{tabular}{|cc|}
\hline Time frame & Budget \\
\hline $2017-$ ongoing & $\$ 100,000-\$ 499,000$ \\
\hline
\end{tabular}




\section{Contact}

Frederic H. Wilson, ASC, fwilson@usgs.gov, (907) 786-7448

Recent Publications

Blodgett, R.B., Wilson, F.H., Shew, N.B., and Clough, J.G., 2020, Bedrock geologic map of the 15' Sleetmute A-2 quadrangle, southwestern Alaska: U.S. Geological Survey Scientific Investigations Map 3450, 18 p., 1 map sheet, scale 1:63,360, https://doi.org/10.3133/sim3450.

Goldfarb, R.J., Meighan, C., Meinert, L., and Wilson, F.H., 2016, Mineral deposits and metallogeny of Alaska, chap. 1 of Boyd, R., Bjerkgard, T., Nordahl, B., and Schiellerup, H., eds., Mineral resources in the Arctic: Geological Survey of Norway Special Publication, p. 12-20, https://pubs.er.usgs.gov/publication/70188828.

Koeneman, L.L., and Wilson, F.H., comps., 2018, Legacy K/Ar and ${ }^{40} \mathrm{Ar}{ }^{39} \mathrm{Ar}$ geochronologic data from the Alaska-Aleutian Range batholith of south-central Alaska: U.S. Geological Survey Open-File Report 2018-1033, 8 p., 1 plate,

https://doi.org/10.3133/ofr20181033.

Wilson, F.H., 2018, Surficial geologic map of the Dillingham quadrangle, southwestern Alaska: U.S. Geological Survey Scientific Investigations Map 3388, 1 sheet, 15 p., scale 1:250,000, https://doi.org/10.3133/sim3388.

\section{Project Links}

https://ardf.wr.usgs.gov/

https://alaska.usgs.gov/portal/project.php?project_id=212

https://alaska.usgs.gov/portal/project.php?project_id=214

\section{Geographic Information System Prospectivity Analysis for Critical Minerals in Ore-Forming Systems in Alaska}

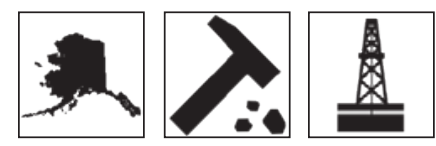

The primary objective of the project is to quantify and understand the distribution of critical elements - elements needed for technological, economic, and military applications-in ore-forming systems in Alaska. This is accomplished using data-driven geographic information system (GIS)-based methods that systematically and simultaneously analyze geospatially referenced datasets and provide an unbiased, quantitative product for large areas that are characterized by diverse types of geological, geochemical, and geophysical data. Our products are high resolution prospectivity analyses and maps for critical elements at the scale of about 100-square-kilometer drainage basins. Project objectives include (1) providing statewide mineral prospectivity maps for specified critical minerals, (2) identifying new areas in Alaska that have resource potential for specified minerals, (3) identifying understudied areas that warrant further investigation for these minerals, (4) identifying areas where data coverage is insufficient and requires future sampling,

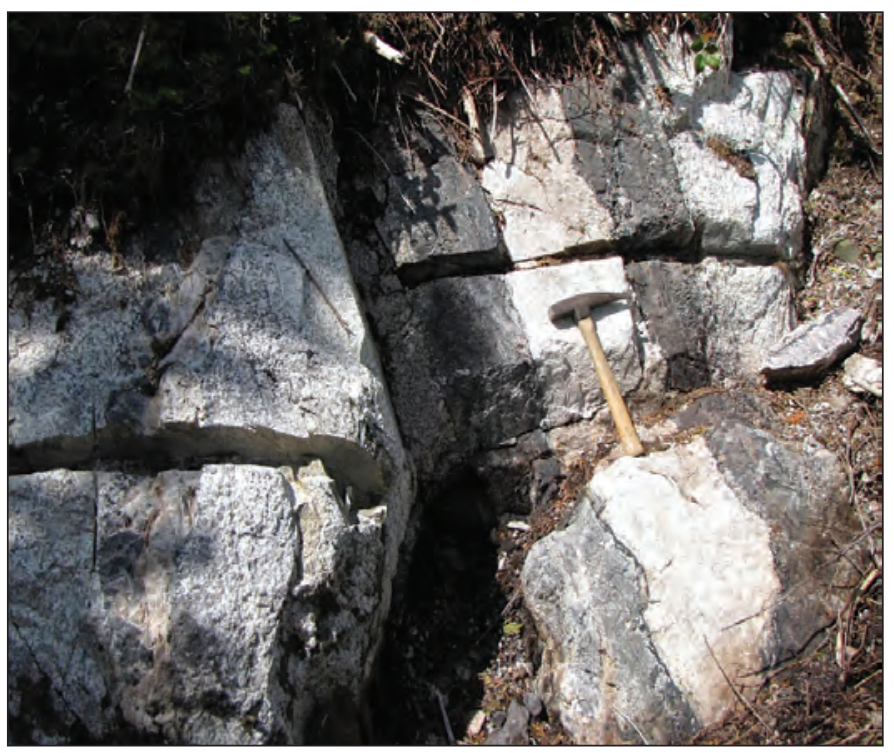

Rare earth element-mineralized dikes on Dotson Ridge, Southeast Alaska. Black bands are dikes that are rich in rare earth elementbearing minerals and oxides. White band is an aplite dike composed of quartz and feldspar. Host rock to these dikes is quartz diorite. Hammer is for scale. Photograph by Susan Karl, U.S. Geological Survey. 
(5) acquiring new data for areas for which data coverage is poor, (6) augmenting datasets, and (7) acquiring or constructing new appropriate datasets. Current investigations address tungsten in granite, skarns, and orogenic gold deposits; cobalt and germanium in sediment-hosted base metal deposits; rhenium and platinum group elements in porphyry systems; and graphite in metamorphic and igneous hydrothermal systems.

\begin{tabular}{ccc}
\hline Time frame & Budget & Project partners \\
\hline $2018-21$ & $\$ 100,000-\$ 500,000$ & $\begin{array}{c}\text { Alaska Division of Geological and Geophysical Surveys, Bureau of Land Management, } \\
\text { Colorado School of Mines }\end{array}$ \\
\hline
\end{tabular}

\section{Contact}

Susan Karl, ASC, skarl@usgs.gov, (907) 786-7428

\section{Recent Publications}

Granitto, M., Wang, B., Shew, N.B., Karl, S.M., Labay, K.A., Werdon, M.B., Seitz, S.S., and Hoppe, J.E., 2019, Alaska Geochemical Database Version 3.0 (AGDB3) - Including "best value" data compilations for rock, sediment, soil, mineral, and concentrate sample media: U.S. Geological Survey Data Series 1117, 33 p., https://doi.org/10.3133/ds1117.

Jones, J.V., III, Karl, S.M., Labay, K.A., Shew, N.S., Granitto, M., Hayes, T.S., Mauk, J.L., Schmidt, J.M., Todd, E., Wang, B., Werdon, M.B., and Yager, D.B., 2015, GIS-based identification of areas with mineral resource potential for six selected deposit groups, Bureau of Land Management Central Yukon Planning Area, Alaska: U.S. Geological Survey Open-File Report 2015-1021, 78p., 2 app., 12 pls., http://dx.doi.org/10.3133/ofr20151021.

Karl, S.M., Jones, J.V., III, and Hayes, T.S., eds., 2016, GIS-based identification of areas that have resource potential for critical minerals in six selected groups of deposit types in Alaska: U.S. Geological Survey Open-File Report 2016-1191, 99 p., 5 app., 12 pls., scale 1:10,500,000, http://dx.doi.org/10.3133/ofr20161191.

Karl, S.M., and Labay, K.A., 2017, Geospatial analysis identifies critical mineral-resource potential in Alaska: U.S. Geological Survey Fact Sheet 2017-3012, 4 p., https://doi.org/10.3133/fs20173012.

Karl, S.M., Labay, K.A., Shew, N.S., Wang, B., Granitto, M., Kreiner, D., and Case, G., 2017, GIS-based identification of areas that have potential for lode gold deposits in Alaska: Association for Mineral Exploration Roundup Annual Convention, Vancouver, British Columbia, Canada, poster, 5 maps scale, 1:5,000,000, https://alaska.usgs.gov/products/poster/2017_Roundup_ poster_Au-Karl.pdf.

Wang, B, Ellefsen, K.J., Granitto, M., Kelley, K.D., Karl, S.M., Case, G.N.D., Kreiner, D.C., and Amundson, C.L., 2020, Evaluation of the analytical methods used to determine the elemental concentrations found in the stream geochemical dataset compiled for Alaska: U.S. Geological Survey Open-File Report 2020-1038, 66 p., https://doi.org/10.3133/ofr20201038. 


\section{Improving Understanding of Critical Mineral Potential in the Alaska Outer Continental Shelf}

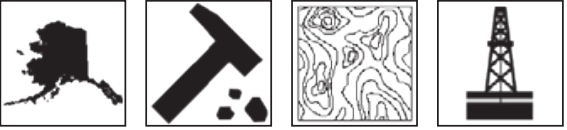

The United States relies on certain mineral commodities, known as critical minerals, that are essential to the economic and national security of the U.S. Under Executive Order 13817, the Federal government is mandated to identify new sources of critical minerals and improve the topographic, geologic, and geophysical mapping to support exploration of critical minerals. USGS seeks to improve knowledge of critical mineral potential in the United States. The objectives of this study are to improve knowledge of marine minerals, including critical marine minerals in the Alaska Outer Continental Shelf, Exclusive Economic Zone, which has been found to contain several types of marine minerals and meets prospective criteria for several others. Methods include a state-of-the-knowledge data synthesis, and an associated update of prospective criteria relevant to the Alaska region. Products will include a data-integrated prospective map, USGS Professional Paper, recommendation of fieldwork, and other products providing guidance to improve understanding of critical marine minerals and their environmental setting; and data relevant to the outcome of any potential extraction on other co-located natural resources.

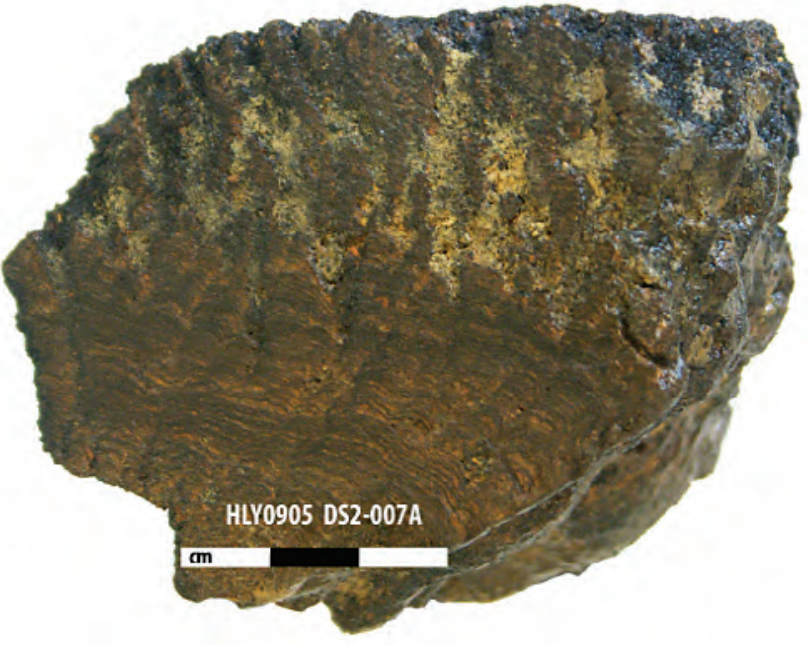

Ferromanganese crust from the Chukchi Plateau and Borderland, Arctic Ocean. From Hein, J.R., and others (2017) (see "Recent Publication" at the end of this section).

\begin{tabular}{ccc}
\hline Time frame & Budget & Project partners \\
\hline $2019-24$ & $\$ 100,000-\$ 499,000$ & Bureau of Ocean Energy Management \\
\hline
\end{tabular}

\section{Contact}

Amy Gartman, Pacific Coastal and Marine Science Center, Santa Cruz, California, agartman@usgs.gov, (831) 460-7562

\section{Recent Publication}

Hein, J.R., Konstantinova, N., Mikesell, M., Mizell, K., Fitzsimmons, J.N., Lam, P.J., Jensen, L.T., Xiang, Y., Gartman, A., Cherkashov, G., Hutchinson, D.R., and Till, C.P., 2017, Arctic deepwater ferromanganese-oxide deposits reflect the unique characteristics of the Arctic Ocean: Geochemistry, Geophysics, Geosystems, v. 18, no. 11, p. 3771-3800, https://doi.org/10.1002/2017GC007186.

\section{Project Link}

https://www.usgs.gov/centers/pcmsc/science/global-ocean-mineral-resources?qt-science_center_objects=0\#qt-science_ center_objects 


\section{Petrogenesis and Mineralization of the Darby and Kachauik Plutons, Seward Peninsula}
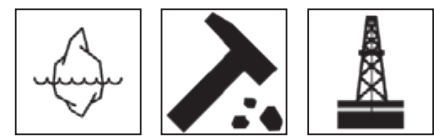

The Darby and Kachauik plutons on the southeastern Seward Peninsula have alkaline compositions with unusually high potassium contents and unevaluated high concentrations of rare earth elements (REE) and high field strength elements (HFSE), which are critically important to modern technology. Project objectives are to investigate the petrogenesis of the alkaline plutons, the sources, mechanisms of transport and concentration of the REE and HFSE, and the tectonic setting in which of these plutons formed. Methods of investigation include mapping rock types and field relations and collecting samples for determination of mineral compositions and paragenesis and for geochemical, geochronologic, and isotopic analysis. These plutons are part of the Hogatza magmatic belt, which extends for 500 kilometers from Saint Lawrence Island to the southern Brooks Range. Resolution of the parameters that controlled the magmatic sources, evolution, mineralization, and emplacement of the Darby and Kachauik plutons will contribute significantly to (1) understanding geologic processes that lead to concentrations of REE and HFSE, (2) defining criteria for evaluating the potential for concentrations of REE and HFSE in the Hogatza magmatic belt and elsewhere, and (3) understanding the regional tectonics of northwestern Alaska.

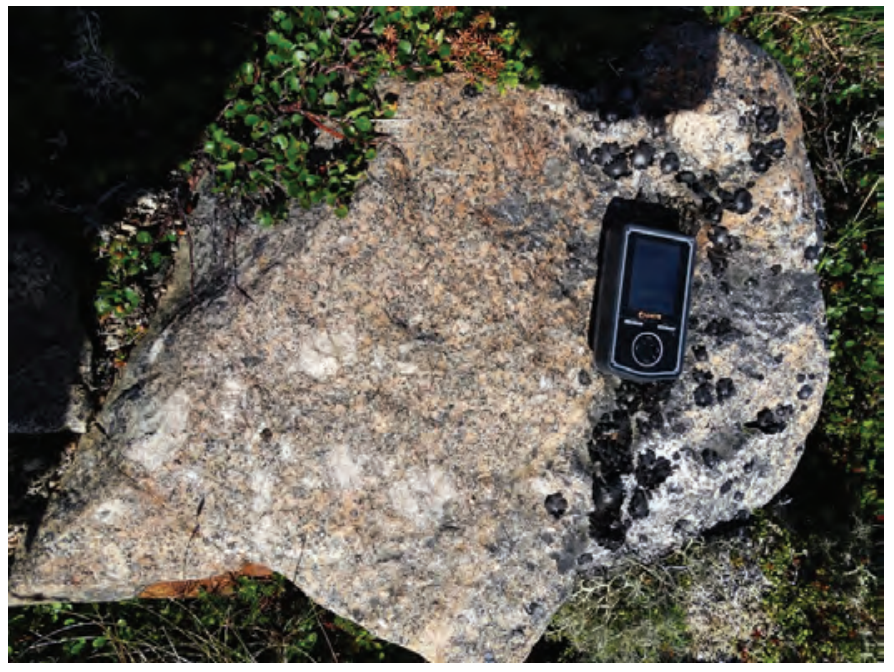

Potassium feldspar megacrysts to 5 centimeter $(\mathrm{cm})$ and tan potassium feldspar phenocrysts to $1 \mathrm{~cm}$ in Kachauik syenite pluton with radioactivity meter, southeastern Seward Peninsula, Alaska. Photograph by Susan Karl, U.S. Geological Survey.

\begin{tabular}{ccc}
\hline Time frame & Budget & Project partners \\
\hline $2017-20$ & $<\$ 100,000$ & $\begin{array}{c}\text { Elim Native Corporation, Bering Straits Native Corporation, Kawerak Inc., a consortium of Tribes, } \\
\text { Villages, and Corporations in the Bering Strait region }\end{array}$ \\
\hline
\end{tabular}

\section{Contact}

Susan Karl, ASC, skarl@usgs.gov, (907) 786-7428 


\section{Mineral Resource Databases and Information Analysis}
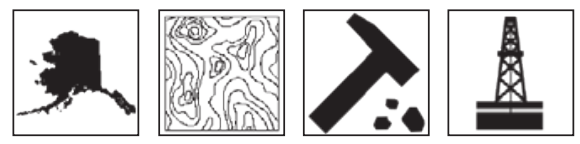

This project, informally called the Alaska GIS project, provides GIS (geographic information system) support to Alaska-based geology research projects. Support includes building geoscience datasets, geospatial analyses, map production, and preparing digital datasets and metadata for publication. The ASC Geology Office finds it beneficial to consolidate most of its GIS proficiency and make it accessible to all projects. With the advent of the era of digital data, the ASC Geology Office and the Mineral Resources Program have been building large statewide (and nationwide) datasets, including geochemistry, geology, mineral resource deposits, and geophysics data. The ASC Geology Office developed a method for spatially analyzing these types of data to identify areas with potential for various type of mineral deposits.

\section{Contact}

Nora B. Shew, ASC,nshew@usgs.gov, (907) 786-7445

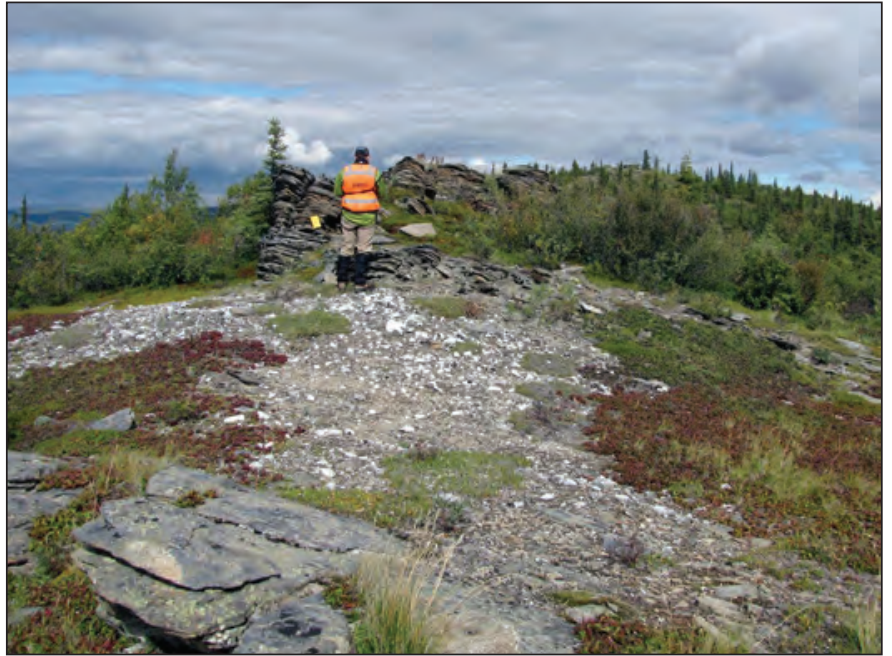

Geologist at Yukon Tanana Uplands, Alaska. Source: U.S. Geological Survey.

\begin{tabular}{|cc|}
\hline Time frame & Budget \\
\hline $1996-$ continuing & $\$ 100,000-\$ 499,000$ \\
\hline
\end{tabular}

\section{Tectonic and Metallogenic Evolution of the Broader Yukon-Tanana Upland}

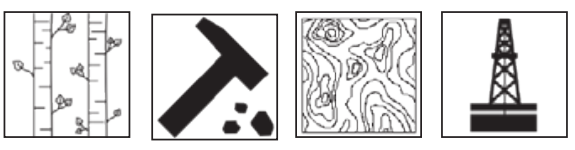

The Yukon-Tanana upland in eastern Alaska contains multiple mining districts and significant placer gold resources. It also hosts a variety of mineral systems that all have known or suspected mineral resource potential for multiple critical mineral commodities. The known mineral deposits and prospects in the region remain poorly characterized, inventoried, and incompletely understood. Furthermore, published geological mapping and data are insufficient for developing a comprehensive geologic and metallogenic framework that is essential for assessing Alaska's mineral resource endowment and identifying fundamental geological controls on mineral deposit formation and preservation. Study methods include (1) new geological mapping and bedrock sampling, (2) focused ore deposit and placer studies and regional characterization of mineralized systems, (3) studies of major fault networks and Cenozoic landscape evolution, and (4) interpretation and modeling of airborne geophysical data. This project is coordinated with new geological, geophysical, and geochemical studies being conducted by the Alaska Division of Geological and Geophysical Surveys under the USGS Earth Mapping Resource Initiative (Earth MRI; https://www.usgs.gov/special-topic/earthmri). The core objectives of the project are to develop a modern and integrated geologic, metallogenic, and geophysical framework of the Yukon-Tanana upland and surrounding regions of eastern interior Alaska.

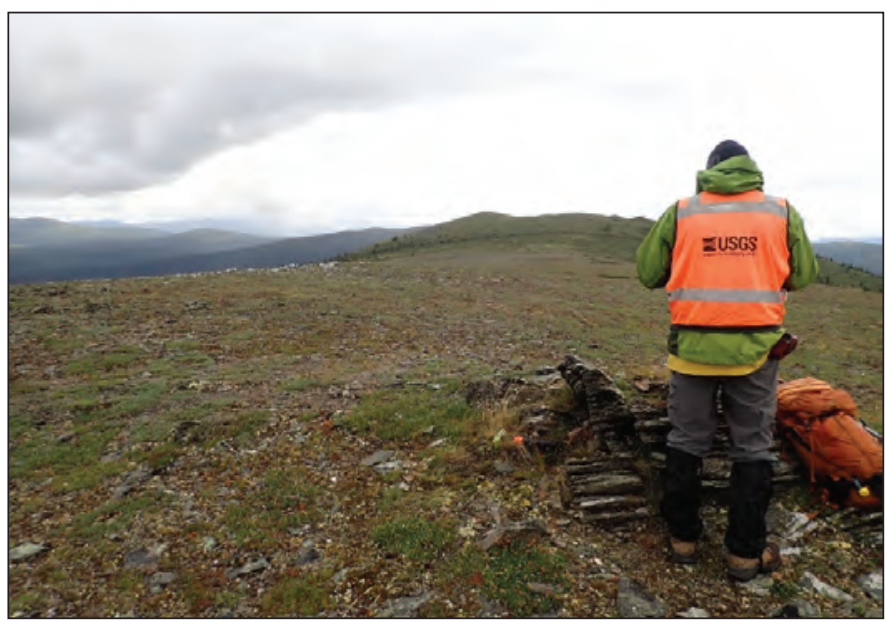

U.S. Geological Survey research geologist examining bedrock outcrops during helicopter-supported geological mapping in the eastern Yukon-Tanana upland, Alaska. Photograph by Jamey Jones, U.S. Geological Survey. 


\begin{tabular}{ccc}
\hline Time frame & Budget & Project partners \\
\hline $2020-24$ & $>\$ 1,000,000$ & $\begin{array}{c}\text { Alaska Division of Geological and Geophysical Surveys, Yukon Geological Survey, and } \\
\text { Geological Survey of Canada }\end{array}$ \\
\hline
\end{tabular}

Contact

Jamey Jones, ASC, jvjones@usgs.gov, (907) 786-7442

Recent Publications

Bender, A.M., Lease, R.O., Corbett, L.B., Bierman, P.R., Caffee, M.W., and Rittenour, T.M., 2020 Climatic pacing of landscape responses to late-Cenozoic Yukon River capture: Nature Geoscience, http://doi.org/10.1038/s41561-020-0611-4.

Oneschuk, D., Miles, W., Saltus, R.W., and Hayward, N., 2019, Alaska and Yukon magnetic compilation, residual total magnetic field (ver. 2.0): Geological Survey of Canada, Open File 7862, 1 sheet, https://doi.org/10.4095/313537. [Supersedes revised edition released in 2017.]

Project Link

https://www.usgs.gov/centers/asc/science/tectonic-and-metallogenic-evolution-yukon-tanana-upland-alaska 


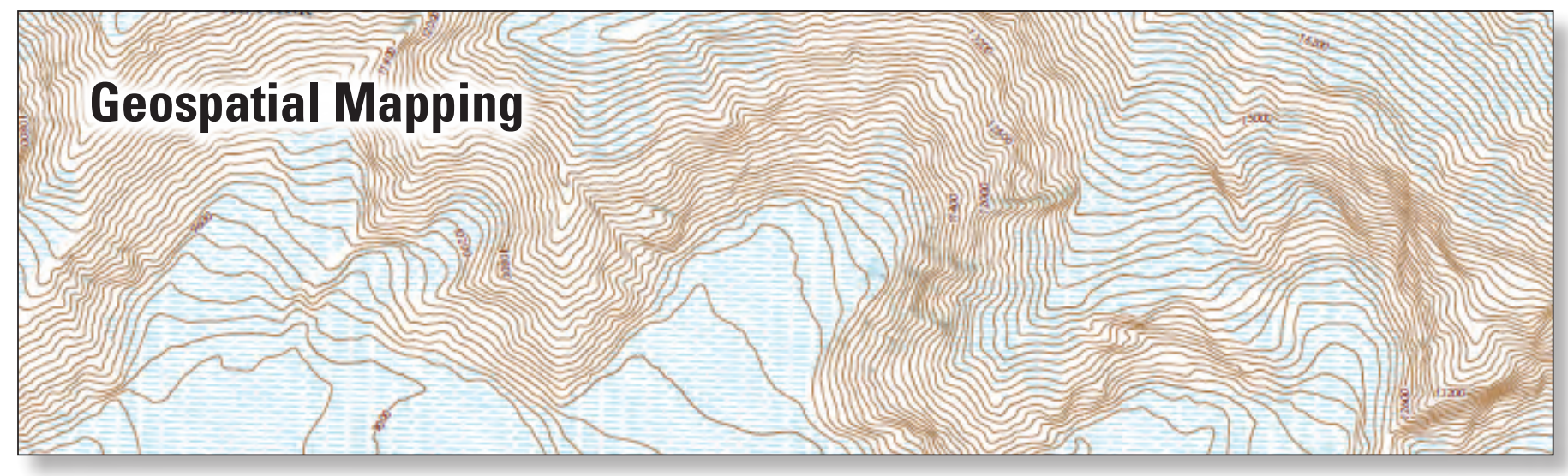

\section{Light Detection and Ranging (Lidar)}

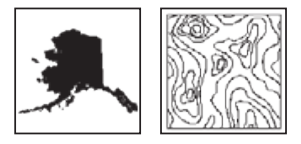

USGS partners with Federal, State, local, and private entities to collect high-quality, three-dimensional (3D) mapping data of the United States. The 3D Elevation Program (3DEP) presents a unique opportunity for collaboration between all levels of government and private organizations to leverage the services and expertise of private-sector mapping firms that acquire 3D elevation data. Federal funds to support this opportunity are provided by the USGS, the Federal Emergency Management Agency, and the Natural Resources Conservation Service. The USGS is acting in a management role to facilitate planning and acquisition for the broader community through the use of government contracts and partnership agreements. All data (digital elevation models) will be made publicly available on the USGS The National Map.

\begin{tabular}{cc}
\hline Time frame & \multicolumn{1}{c}{ Project partners } \\
\hline $2018-21$ & $\begin{array}{c}\text { Federal Emergency Management Agency and the Natural Resources Conservation Service, National Park Service, Ahtna } \\
\text { Native Regional Corporation }\end{array}$ \\
\hline
\end{tabular}

\section{Contact}

Brian Wright, National Geospatial Program, bwright@usgs.gov (907) 201-0113 


\section{Alaska IfSAR Radar Elevation Data Acquisition Program}
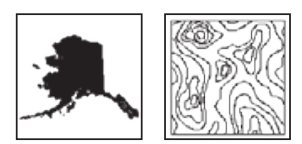

The USGS Alaska Mapping Initiative supports acquisition of new topographic map data and maps for Alaska. The new data and maps raise the accuracy of Alaska topographic mapping to levels common in the conterminous United States. Topographic maps are generated from radar technology referred to as IfSAR (interferometric synthetic aperture radar) elevation data. IfSAR is used to collect the data because it can penetrate the clouds, smoke, and haze that often are present in Alaska. Alaska IfSAR acquisition also supports the broader national 3DEP. Collection of a 5-meter resolution elevation grid for Alaska began in 2012 and was completed in 2020, replacing the former 60 -meter statewide elevation grid. The data are free to the public for any use. New technologies also are being investigated to collect high-resolution elevation data for Alaska in the future.

Contact

Brian Wright, National Geospatial Program, bwright@usgs.gov (907) 201-0113

Project Link

https://www.usgs.gov/core-science-systems/ngp/user-engagement-office/alaska-mapping-initiative

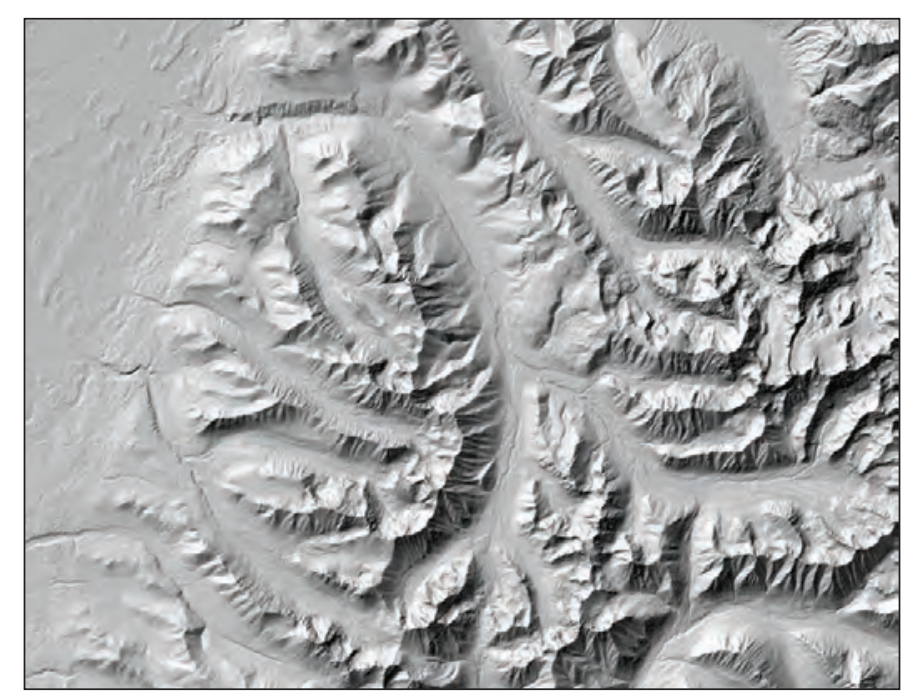

IfSAR (interferometric synthetic aperture radar) elevation shaded relief created using new 5-meter elevation data near Anchorage, Alaska. Image provided by Dave Saghy, U.S. Geological Survey.

\section{Alaska Hydrography Map}

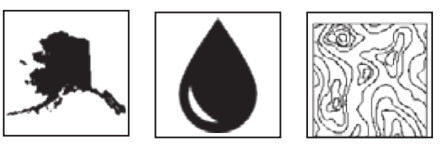

The National Hydrography Dataset (NHD), Watershed Boundary Dataset (WBD), and NHDPlus High Resolution (NHDPlus HR) are geospatial datasets that map and model the surface water of the United States. Together, the NHD and WBD form a rich data suite that maps the Nation's surface-water network and hydrologic unit areas. The NHD at 1:24,000 scale or better represents the Nation's hydrologic drainage networks and related features, including rivers, streams, canals, lakes, ponds, glaciers, coastlines, dams, and stream gauges. The WBD represents drainage areas of the country at eight nested levels. The NHD and WBD are the most up-to-date and geographically inclusive hydrography datasets for the Nation.

In Alaska, most of the mapping of this water is based on 1950s-era USGS historical topographic maps and is mapped at a broad 1:63,360-scale. Numerous partners are engaged in an effort to remap Alaska waters to meet national high-resolution, 1:24,000-scale standards. This work is overseen by the Alaska Geospatial Council Alaska Hydrography Technical

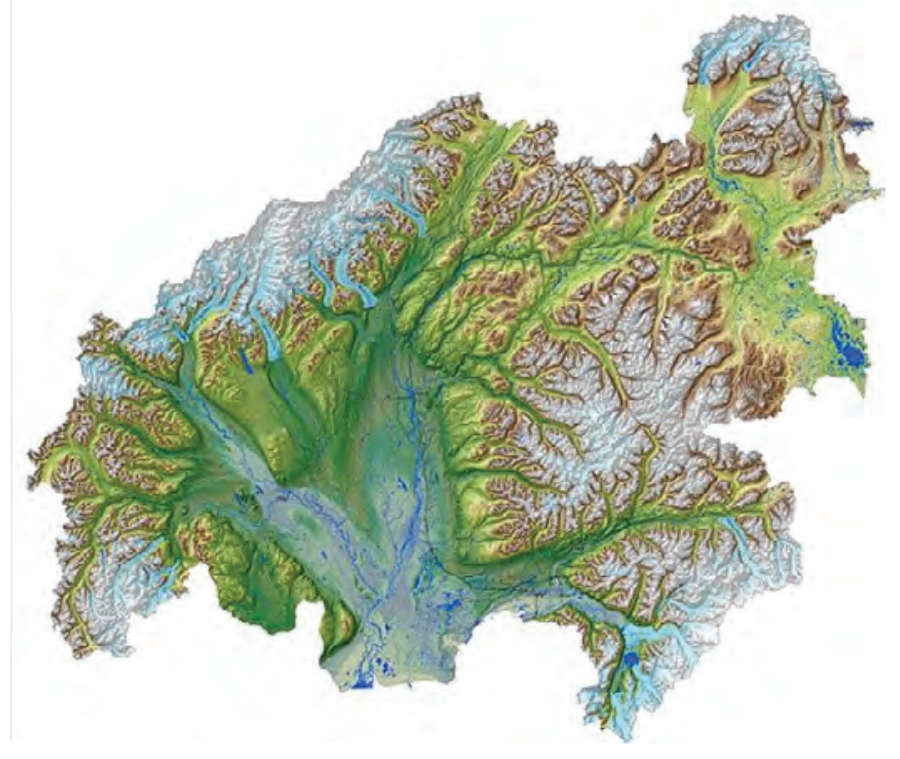

Terrain and hydrography of the Matanuska-

Susitna watershed, south-central Alaska. Image provided by Kacy Krieger, University of Alaska Anchorage. Public domain. 
Working Group, which has two goals: (1) update the NHD to national standards, and (2) meet the hydrography mapping needs of agencies in Alaska. As a result of this collaborative effort, nearly 30 percent of the NHD in Alaska has been updated to the 1:24,000 scale national standard and the data are available to the public. Hydrography updates also include updates to the WBD. The WBD, NHD USGS digital elevation data will be used to generate NHDPlus HR for Alaska in the future. USGS contracted NHD and WBD updates for more than 40,000 square miles of Alaska in FY2020 and contracted NHDPlus HR generation for an additional 35,000 square miles using NHD edited through the Alaska Geospatial Council partnerships. Several automated inspection processes were developed at the USGS National Technical Operations Center to support NHD quality-control review.

\begin{tabular}{cc}
\hline Time frame & \multicolumn{1}{c}{ Project partners } \\
\hline Ongoing & State, Federal, and private partners engaged in the Alaska Geospatial Council \\
\hline
\end{tabular}

\section{Contact}

Brian Wright, National Geospatial Program, bwright@usgs.gov (907) 201-0113

Project Link

http://agc.dnr.alaska.gov/hydrography.html

\section{Landsat 9 Analysis Ready Data}
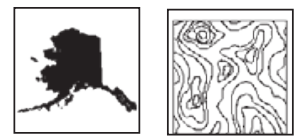

Landsat 9 represents a longstanding partnership between the National Aeronautics and Space Administration (NASA) and the USGS that will continue the Landsat program's critical role of repeat global observations for monitoring, understanding, and managing Earth's natural resources. Since 1972, Landsat data have provided a unique resource for those who work in agriculture, geology, forestry, regional planning, education, mapping, and globalchange research. NASA is responsible for the space segment (instruments and spacecraft/ observatory), mission integration, launch, and on-orbit checkout. The USGS Earth Resources Observation and Science (EROS) Center is responsible for the ground system, flight operations, data processing, and data product distribution after NASA completes on-orbit checkout. The Landsat 9 spacecraft and instruments are being developed towards a launch-readiness date of mid-2021. Landsat 9 will image the Earth every 16 days in an 8-day offset with Land-

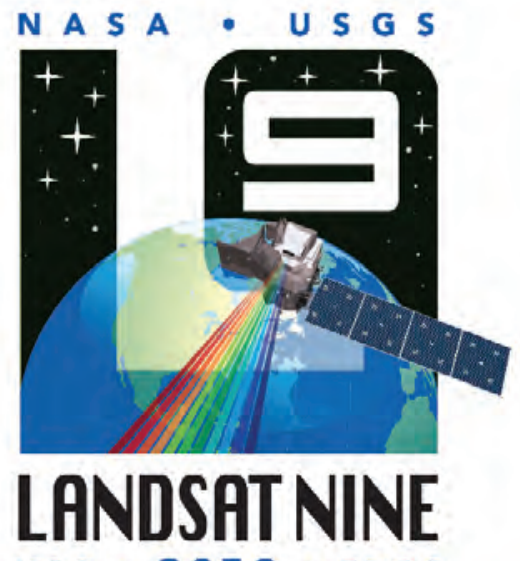
sat 8. Landsat 9 will collect as many as 750 scenes per day, and with Landsat 8, the two satellites will add nearly 1,500 new scenes per day to the USGS Landsat archive. All Landsat 9 data products will continue to be made available for download through the USGS EROS Center at no charge. U.S. Landsat Analysis Ready Data (ARD) products are consistently processed to the highest scientific standards and level of conversion required for direct use in monitoring and assessing landscape change. U.S. Landsat ARD is available for the conterminous United States, Alaska, and Hawaii. In Alaska, USGS scientists and others use Landsat imagery to help land and resource managers make informed decisions about the State's energy and mineral resources and wildlife habitats, as well as to contribute to a greater understanding of geologic processes, coastal erosion, and anticipated future landscape changes. Landsat ARD products include Landsat 4-8 collections and are available for Alaska from 1984 to present, with significant expansion in the number of scenes available for download occurring in 1999 and 2013, and forthcoming after 2020.

\section{Contact}

Chris Crawford, EROS Center, cjcrawford@usgs.gov,(605) 594-2874

\begin{tabular}{cc}
\hline Time frame & Project partners \\
\hline $2015-21$ & $\begin{array}{c}\text { National Aeronautics and Space Administration Kennedy Space } \\
\text { Center and Goddard Space Flight Center }\end{array}$ \\
\hline
\end{tabular}

\section{Recent Publication}

U.S. Geological Survey, 2019, Landsat 9 (ver. 1.2,April 2020): U.S. Geological Survey Fact Sheet 2019-3008, 2 p., https://doi.org/10.3133/fs20193008. [Supersedes version 1.1, released in 2019.] 


\section{Arctic Research Policy Act (ARPA) Boundary Maps}
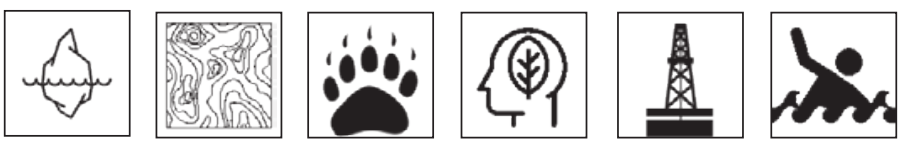

The Alaska Regional Office worked with the Core Science System Mission Area on a shared objective to develop three new Arctic Research Policy Act (ARPA) boundary maps that seek to provide value-added attributes for marine and terrestrial domains as a second-generation update to the boundary map for U.S. Arctic Research Commission and National Science Foundation (see https://storage.googleapis.com/ arcticgov-static/publications/maps/ ARPA_Alaska_and_Polar.pdf). The fundamental rationale for the update is the increasing relevance of Arctic issues to national and global affairs that requires more precise and functional projections.

One of the three ARPA maps depicts the ARPA boundary as it relates to Alaska and the Bering Sea (https://www.usgs.gov/media/ files/arctic-research-and-policyact-boundary-map-bering-sea). The second map depicts the boundary

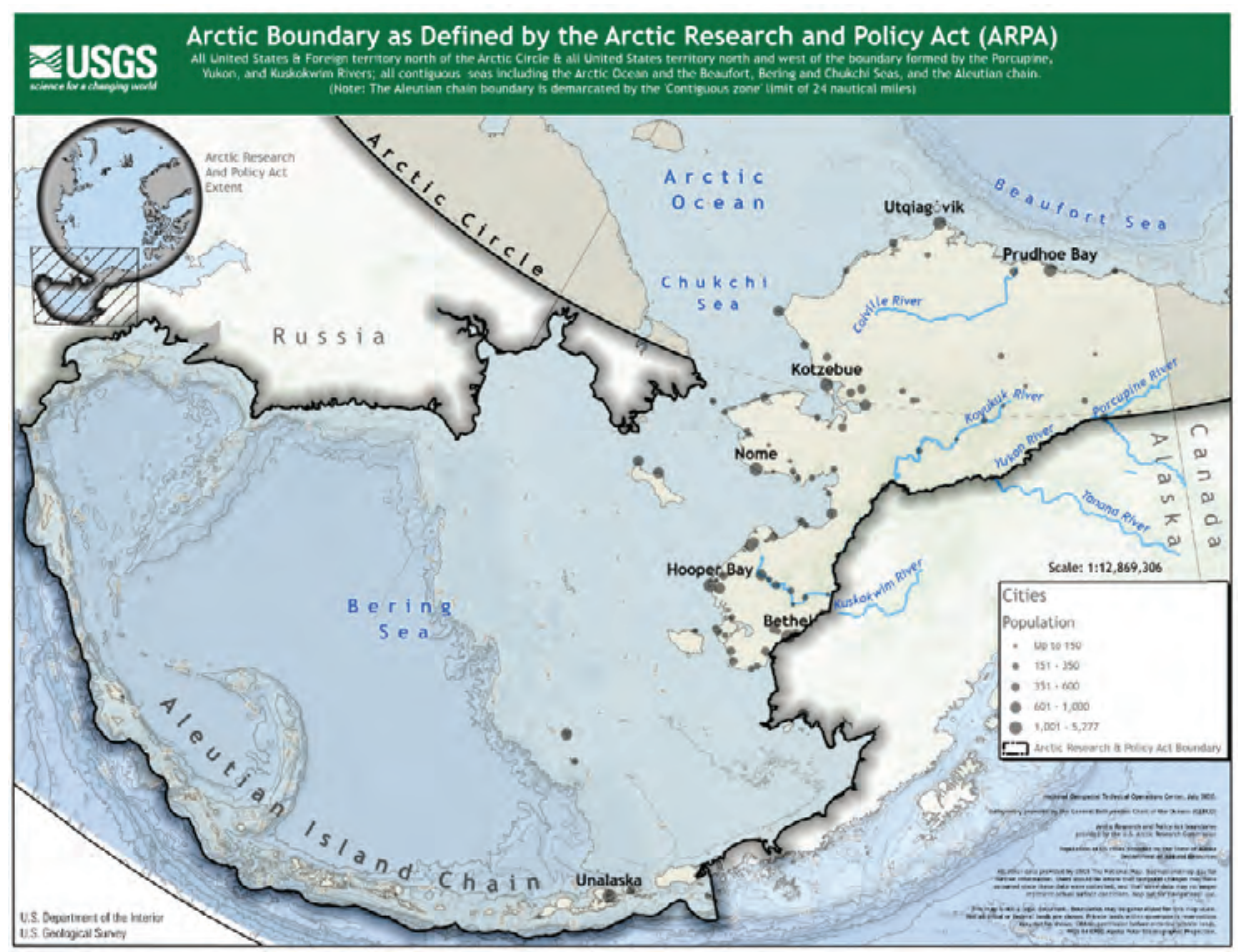

Arctic Research Policy Act boundary as it relates to Alaska and the Bering Sea. Image provided by U.S. Geological Survey National Geospatial Technical Operations Center. from a circumpolar perspective (https://www.usgs.gov/media/files/arctic-research-and-policy-act-boundary-map-circumpolar). The third map depicts in poster size detail the boundary as it relates to terrestrial features of Arctic Alaska (https://www.usgs. gov/media/files/arctic-research-and-policy-act-boundary-map-alaska-terrestrial). With respect to methods, the new maps were customized to show many new "value added" attributes such as updated bathymetry and shoreline refinements, demographic information, conservation areas, terrestrial land cover, annual sea ice maximum extent, annual circumpolar $10^{\circ} \mathrm{C}$ isotherm, and enhanced metadata information. The static pdf maps offer value as stand-alone products but are intended to be used in conjunction with an interactive website allowing users to access the various map layers in a dynamic up-to-date environment.

\begin{tabular}{ccc}
\hline Time frame & Budget & Project partners \\
\hline 2020 & $<\$ 100,000$ & $\begin{array}{c}\text { U.S. Arctic Research Commission, National Oceanic and Atmospheric Administration, } \\
\text { Department of State }\end{array}$ \\
\hline
\end{tabular}

\section{Contact}

Dee Williams, Alaska Regional Office,dmwilliams@usgs.gov, (907) 786-7023 


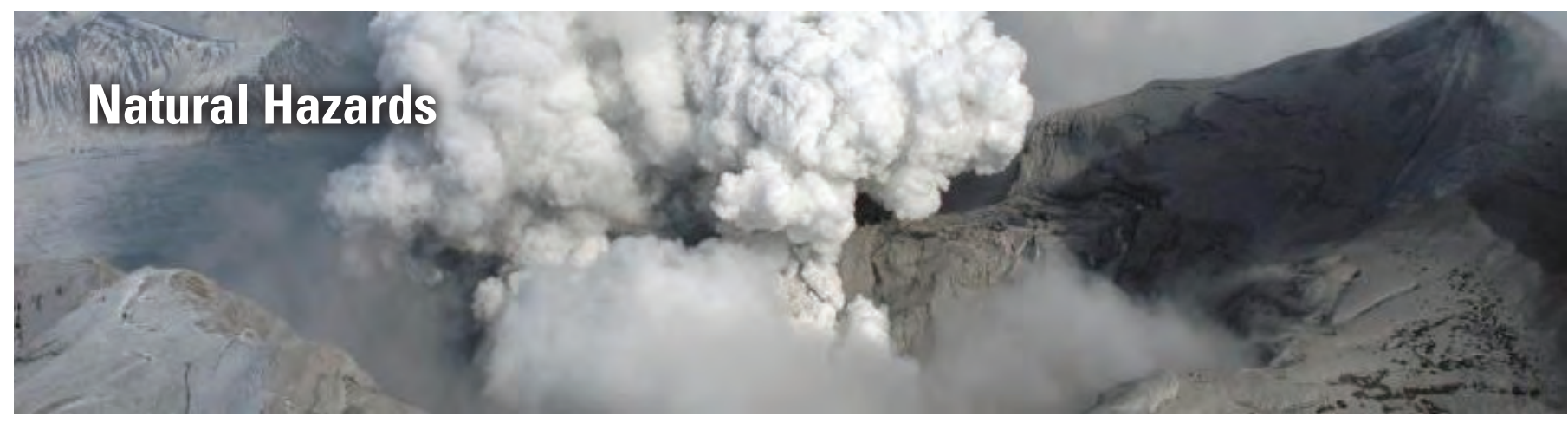

\section{Earthquakes and Tsunamis}

\section{Alaska Earthquake Hazards}
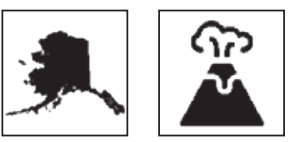

The major fault systems in Alaska, including the Denali and Queen Charlotte-Fairweather Faults, and the Alaska-Aleutian subduction zone, have produced large earthquakes that threaten lives and property. Many active faults, especially structures along the subduction zone, can generate large tsunamis that will threaten Alaskan coastal communities and propagate across the Pacific Ocean causing impacts to Hawaii and Western U.S. mainland coast. The main objectives of the Alaska Earthquake Hazards Project focus on more accurately defining the location, magnitude, and frequency of prehistoric earthquakes and tsunamis, which inform probabilistic assessments that forecast future hazards. Using methods in paleoseismology, geochronology, and quantitative geomorphology, the research team conducts field-based studies to understand how, where, and why earthquakes and tsunamis occur in Alaska. Expected outcomes include seismic and tsunami source parameters used to update the National Seismic Hazard Map for Alaska. Research findings also inform tsunami hazard assessments conducted by States and Territories with support from the National Oceanic and Atmospheric Administration (NOAA) National Tsunami Hazard Mitigation Program.

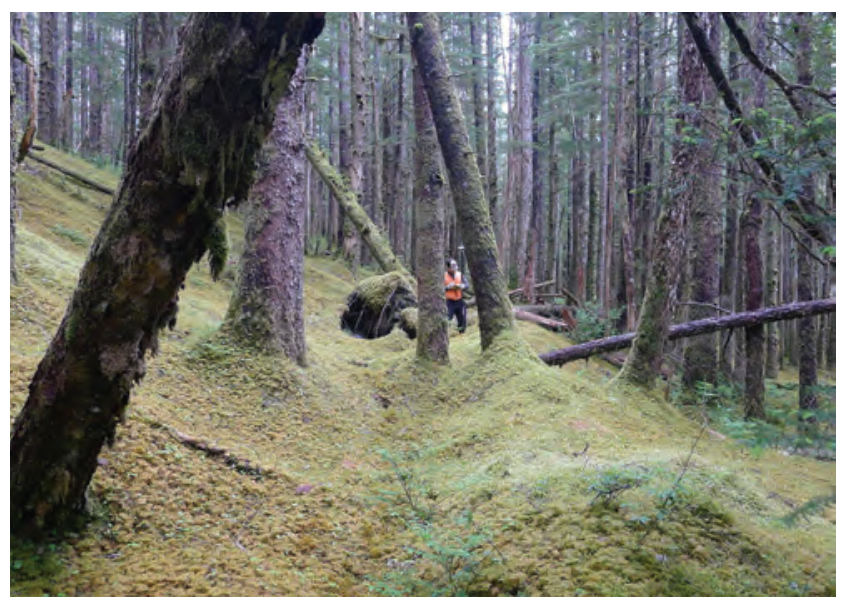

U.S. Geological Survey geologist surveying a trace of the 1958 Fairweather Fault earthquake surface rupture, at Crillon Lake, Glacier Bay National Park, Southeast Alaska. Trace forms a linear, uphill-facing, 1-2-meter tall escarpment flanked by trees that likely were tilted during the 1958 earthquake. Photograph by Rob Witter, U.S. Geological Survey.

\begin{tabular}{ccc}
\hline Time frame & Budget & \multicolumn{1}{c}{ Project partners } \\
\hline $2007-20$ & $\$ 100,000-\$ 499,000$ & $\begin{array}{l}\text { U.S. Army Corps of Engineers Cold Regions Research and Engineering Laboratory, Alaska Division of } \\
\text { Geological and Geophysical Surveys, University of Durham, Virginia Polytechnic Institute and State } \\
\text { University, University of Washington, Boise State University, Ghent University, Cortland State } \\
\text { University, Michigan State University, University of Alaska Fairbanks, Oregon State University }\end{array}$ \\
\hline
\end{tabular}

\section{Contact}

Robert Witter, ASC, rwitter@usgs.gov, (907) 786-7404

\section{Recent Publications}

Grant, A.R.R., Jibson, R.W., Witter, R.C., Allstadt, K.E., Thompson, E.M., and Bender, A.M., 2020, Ground failure triggered by shaking during the November 30, 2018, magnitude 7.1 Anchorage, Alaska, earthquake: U.S. Geological Survey Open-File Report 2020-1043, 21 p. https://doi.org/10.3133/ofr20201043. 
Jibson, R.W., Grant, A.R.R., Witter, R.C., Allstadt, K.E., Thompson, E.M., and Bender, A.M., 2019, Ground failure from the Anchorage, Alaska, earthquake of 30 November 2018: Seismological Research Letters, v. 91, p. 19-32, https://doi.org/10.1785/0220190187.

Witter, R., Briggs, R., Engelhart, S.E., Gelfenbaum, G., Koehler, R.D., Nelson, A.R., La Selle, S., Corbett, D.R., and Wallace, K.L., 2019, Evidence for frequent, large tsunamis spanning locked and creeping parts of the Aleutian megathrust: Geological Society of America Bulletin, v. 131, p. 707-729, https://doi.org/10.1130/B32031.1.

\section{Project Link}

https://www.usgs.gov/centers/asc/science/alaska-earthquake-and-tsunami-hazards

\section{Barry Arm Landslide Motion and Tsunami Potential}
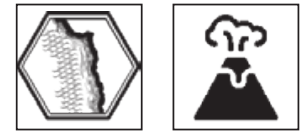

In May 2020, local geologists identified a steep, unstable slope with the potential to become a massive tsunami-generating landslide in Barry Arm near Prince William Sound that could impact marine and recreational interests and the community of Whittier. The USGS is working with Federal and State partners to better understand the threat that the Barry Arm slide poses with an overall objective of guiding future surveillance and alerting strategies. Specific 2020 objectives were to: (1) map landslide features using engineering geologic methods and aerial lidar and optical imagery, (2) surveil landslide motion using satellite radar data and synthetic interferometric methods, and (3) collect bathymetric and geophysical data to define the submarine extent of the slide. A series of public meetings have been held and more are planned to provide information and assurance to the residents of this region.

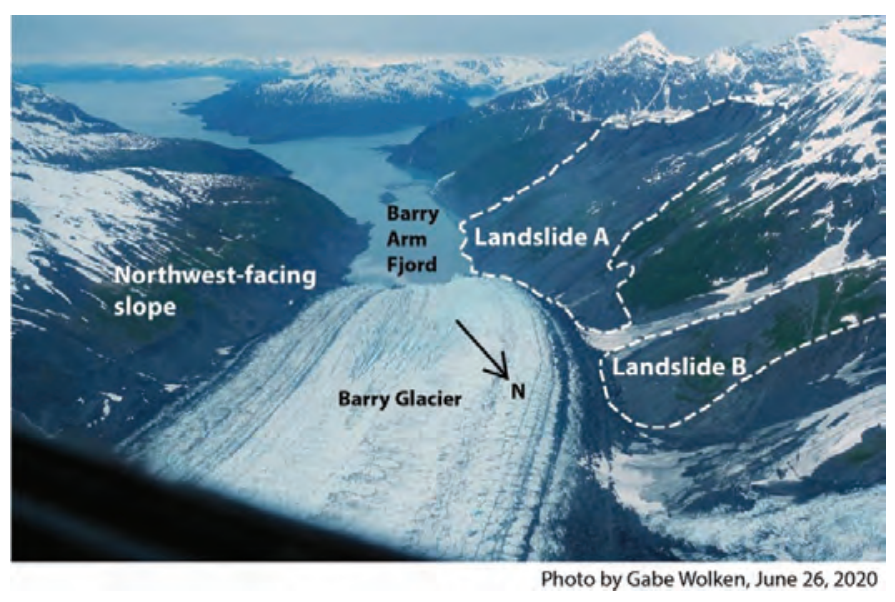

Landslide areas of Barry Arm Fjord, Prince William Sound, Alaska. Subaerial landslides at the head of Barry Arm Fjord in southern Alaska could generate tsunamis (if they rapidly failed into the fjord) and, therefore, are a potential threat to people, marine interests, and infrastructure throughout the Prince William Sound region. Annotated photograph by Gabe Wolken, Alaska Division of Geological and Geophysical Surveys.

\begin{tabular}{ccc}
\hline Time frame & Budget & \multicolumn{1}{c}{ Project partners } \\
\hline 2020 -ongoing & $\$ 100,000-\$ 500,000$ & $\begin{array}{l}\text { Alaska Division of Geological and Geophysical Surveys, National Oceanic and Atmospheric } \\
\text { Administration (NOAA) National Tsunami Warning Center, NOAA Coast Survey, U.S. Forest } \\
\end{array}$ \\
& & Service, National Geospatial Agency \\
\hline
\end{tabular}

\section{Contact}

Jeffrey Coe, Geological Hazards Science Center, jcoe@usgs.gov, (303) 273-8606

\section{Recent Publications}

Schaefer, L.N., Coe, J.A., Godt, J.W., and Wolken, G.J., 2020, Interferometric synthetic aperture radar data from 2020 for landslides at Barry Arm Fjord, Alaska (ver. 1.4, November 2020): U.S. Geological Survey data release, https://doi.org/10.5066/P9Z04LNK. [Supersedes version 1.3, released in 2020.]

\section{Project Link}

https://dggs.alaska.gov/hazards/barry-arm-landslide.html 


\section{Offshore Crustal Imaging of the Queen Charlotte Fault System to Characterize Deformation and Seismic Hazard in Southeastern Alaska}
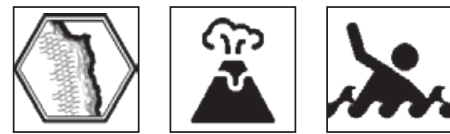

Often called the "San Andreas of the North", the Queen Charlotte Fault (QCF) system is a strike-slip plate boundary that separates the Pacific and North American tectonic plates offshore western Canada and Southeast Alaska. The fault system represents the largest seismic hazard to southeastern Alaska and Canada outside Cascadia and caused Canada's largest recorded earthquake (Magnitude 8.1) in 1949. Offshore crustal imaging of the Queen Charlotte Fault system is needed to characterize deformation and seismic hazard in southeastern Alaska. The objectives of this study are to characterize this plate boundary on a regional scale. Methods include using seismic energy from marine acoustic and earthquake sources to measure the depth and extent of seismicity, image the fault zone at depth, and determine velocity and thermal structure across the fault. This information will lead to an improved understanding of the QCF Fault system and other major strikeslip fault systems for better hazard assessment and earthquake forecasting.

\begin{tabular}{ccc}
\hline Time frame & Budget & Project partners \\
\hline $2020-21$ & $\$ 100,000-\$ 500,000$ & $\begin{array}{c}\text { Sitka Sound Science Center, University of New Mexico, University of Washington, Dalhousie } \\
\text { University, National Science Foundation, Geological Survey of Canada }\end{array}$ \\
\hline
\end{tabular}

\section{Contact}

Maureen Walton, Pacific Coastal and Marine Science Center, mwalton@usgs.gov, (831) 460-7529

Project Link

https://qcfhazards.net/

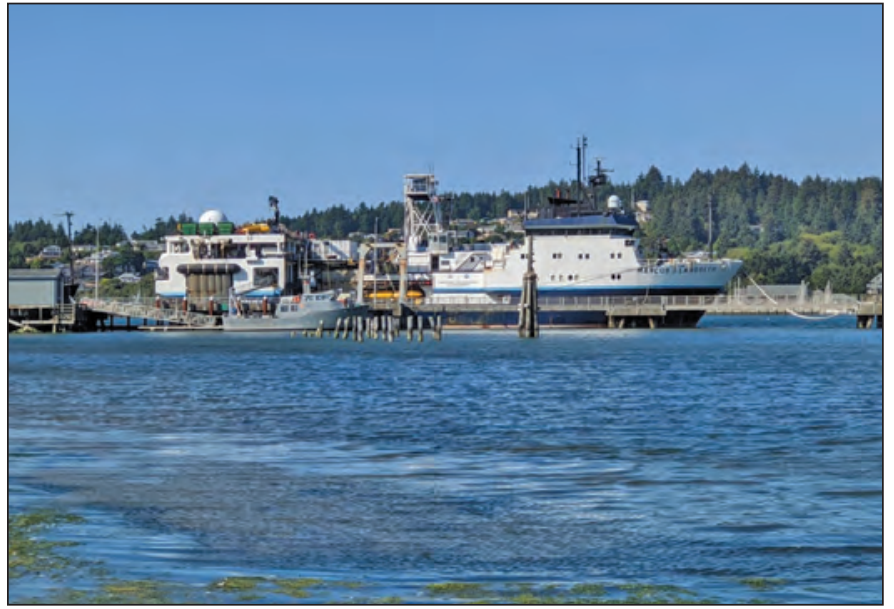

U.S. National Science Foundation-funded seismic research vessel (white boat) R/V Marcus G. Langseth at port in Newport, Oregon, August 2020. Photograph by Maureen Walton, U.S. Geological Survey. 


\section{Volcanoes}

\section{Alaska Volcano Observatory}
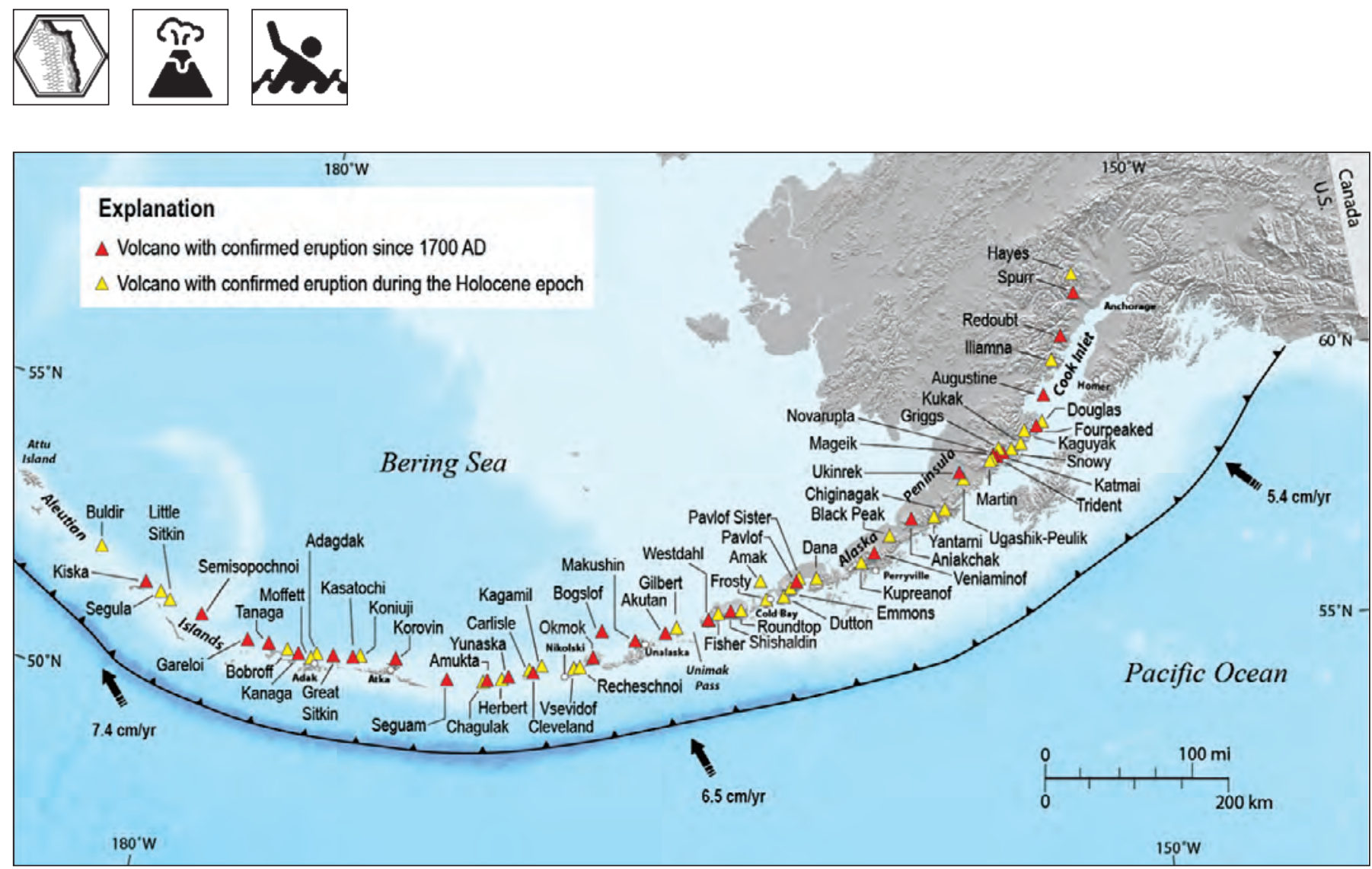

Volcanoes in Alaska. Alaska Volcano Observatory uses various methods including real-time geophysical networks and data collected by satellite to monitor activity at Alaskan volcanoes stretching from Mount Hayes, 141 kilometers (km) from Anchorage, to Kiska, 2,198 km from Anchorage.

Alaska has 54 historically active volcanoes and about 100 volcanoes active in the past 11,000 years. The primary hazard from eruptions is airborne ash, although several communities are vulnerable to ashfall, or more rarely, flowage hazards. The AVO is a joint program of the USGS, the Geophysical Institute of the University of Alaska Fairbanks, and the Alaska Division of Geological and Geophysical Surveys, was formed in 1988, and accomplishes the following objectives: (1) to monitor and study Alaska's hazardous volcanoes, (2) to predict and record eruptive activity, and (3) to mitigate volcanic hazards to life and property. AVO uses several monitoring methods including seismic stations at 32 volcanoes, continuous Global Positioning System (GPS) stations at 8 volcanoes, regional and local infrasound sensors, and web cameras. In addition to ground-based monitoring, AVO relies on satellite data and other remote data streams to detect volcanic unrest and eruptions. AVO produces formal information products regarding volcanic activity and hazards (https://volcanoes.usgs.gov/vns2/); journal articles and USGS publications on volcanic processes, methods, and hazards; and hazards assessments and geologic maps.

\begin{tabular}{ccc}
\hline Time frame & Budget & \multicolumn{1}{c}{ Project partners } \\
\hline 1998 -ongoing & $>\$ 1,000,000$ & $\begin{array}{c}\text { Alaska Division of Geological and Geophysical Surveys, University of Alaska Fairbanks } \\
\text { Geophysical Institute }\end{array}$ \\
\hline
\end{tabular}

\section{Contact}

Michelle Coombs, Volcano Science Center, mcoombs@usgs.gov, (907) 250-3984 


\section{Project Link}

https://avo.alaska.edu/

\section{Recent Publications}

Bergfeld, D., Evans, W.C., Hunt, A.G., Lopez, T., and Schaefer, J.R., 2020, A post-eruption study of gases and thermal waters at Okmok volcano, Alaska: Journal of Volcanology and Geothermal Research, v, 396, 16 p., https://doi.org/10.1016/j.jvolgeores.2020.10685.

Cameron, C.E., Schaefer, J.R., and Ekberg, P.G., 2020, Historically active volcanoes of Alaska: Alaska Division of Geological \& Geophysical Surveys Miscellaneous Publication 133, v. 4, 2 sheets, https://doi.org/10.14509/30426.

Coombs, M., Wallace, K., Cameron, C., Lyons, J., Wech, A., Angeli, K., and Cervelli, P., 2019, Overview, chronology, and impacts of the 2016-2017 eruption of Bogoslof volcano, Alaska: Bulletin of Volcanology, v. 81, no. 62, 23 p., https://doi.org/10.1007/s00445-019-1322-9.

De Angelis, S.H., Larsen, J.F., Coombs, M.L., Utley, J.E.P., and Dunn, A., 2020, Phase equilibrium of a high- $\mathrm{SiO}_{2}$ andesite at $f_{\mathrm{O} 2}=\mathrm{RRO}$ - Implications for Augustine Volcano and other high $-f_{\mathrm{O} 2}$ arc andesites: Contributions to Mineralogy and Petrology, v. 175, no. 24, 20 p., https://doi.org/10.1007/s00410-020-1663-6.

Dixon, J.P., Stihler S.D., Haney, M.M., Lyons, J.J., Ketner, D.M., Mulliken, K.M., Parker, T., and Power, J.A., 2019, Catalog of earthquake parameters and description of seismograph and infrasound stations at Alaskan volcanoes-January 1, 2013, through December 31, 2017: U.S. Geological Survey Data Series 1115, 92 p., https://doi. org/10.3133/ds 1115 .

Fee, D., Lyons, J., Haney, M., Wech, A., Waythomas, C., Diefenbach, A.K., Lopez, T., Van Eaton, A., and Schneider, D., 2020, Seismo-acoustic evidence for vent drying during shallow submarine eruptions at Bogoslof volcano, Alaska: Bulletin of Volcanology, v. 82, no. 2, 14 p., https://doi. org/10.1007/s00445-019-1326-5.

Haney, M.M., Fee, David, McKee, K.F., Lyons, J.J., Matoza, R.S., Wech, A.G., Tepp, Gabrielle, Searcy, Cheryl, and Mikesell, T.D., 2020, Co-eruptive tremor from Bogoslof volcano: seismic wavefield composition at regional distances: Bulletin of Volcanology, v. 82, 14 p., https://doi.org/10.1007/s00445-019-1347-0.

Loewen, M.L., Izbekov, P., Moshrefzadeh, J., Coombs, M., Larsen, J., Graham, N., Waythomas, C., and Wallace, K., 2019, Petrology of the 2016-2017 eruption of Bogoslof Island, Alaska: Bulletin of Volcanology v. 81, n. 72, 20 p., https://doi.org/10.1007/s00445-019-1333-6.
Lopez, T., Lieven, C., Schwaiger, H., Van Eaton, A., Loewen, M., Fee, D., Lyons, J., Wallace, K., Searcy, C., Wech, A., Haney, M., Schnieder, D., and Graham, N., 2020, Constraints on eruption processes and event masses for the 2016-2017 eruption of Bogoslof volcano, Alaska, through evaluation of IASI satellite $\mathrm{SO}_{2}$ masses and complementary datasets: Bulletin of Volcanology, v. 82, no. 17, 17 p., https://doi.org/10.1007/s00445-019-1348-z.

Lyons, J.J., Haney, M.M., Fee, D., Wech, A.G., and Waythomas, C.F., 2019, Infrasound from giant bubbles during explosive submarine eruptions: Nature Geoscience, v. 12, p. 952-958, https://doi.org/10.1038/s41561-019-0461-0.

Power, J.A., Haney, M.M., Botnick, S.M., Dixon, J.P., Fee, David, Kaufman, A.M., Ketner, D.M., Lyons, J.J., Parker, T., Paskievitch, J.F., Read, C.W., Searcy, C., Stihler, S.D., Tepp, G., and Wech, A.G., 2020, Goals and development of the Alaska Volcano Observatory seismic network and application to forecasting and detecting volcanic eruptions: Seismological Research Letters, v. 91, no. 2A, p. 647-659, https://doi.org/10.1785/0220190216.

Sanderson, R.W., Matoza, R.S., Fee, D., Haney, M.M., and Lyons, J.J., 2020, Remote detection and location of explosive volcanism in Alaska with the EarthScope Transportable Array: Journal of Geophysical Research Solid Earth, v. 125, 23 p., https://doi.org/10.1029/2019JB018347.

Schaefer, J.R.G., Perreault, J.M., Larsen, J.F., and Vallance, J.W., 2020, Makushin Volcano ash hazards: Alaska Division of Geological \& Geophysical Surveys Information Circular 86, 2 p., https://doi.org/10.14509/30411.

Schneider, D.J., Van Eaton, A.R., and Wallace, K.L., 2020, Satellite observations of the 2016-2017 eruption of Bogoslof volcano-Aviation and ash fallout hazard implications from a water-rich eruption: Bulletin of Volcanology, v. 82, no. 29, 20 p., https://doi.org/10.1007/s00445-020-1361-2.

Schwaiger, H.F., Lyons, J.J., Iezzi, A.M., Fee, D., and Haney, M.M., 2020, Evolving infrasound detections from Bogoslof volcano, Alaska-Insights from atmospheric propagation modeling: Bulletin of Volcanology, v. 82, no. 27, 14 p., https://doi.org/10.1007/s00445-020-1360-3.

Searcy, C., and Power, J.A., 2020, Seismic character and progression of explosive activity during the 2016-2017 eruption of Bogoslof volcano, Alaska: Bulletin of Volcanology, no. 82, 15 p., https://doi.org/10.1007/s00445-019-1343-4.

Tepp, G., Dziak, R.P., Haney, M.M., Lyons, J.J., Searcy, C., Matsumoto, H., and Haxel, J., 2020, Seismic and hydroacoustic observations of the 2016-17 Bogoslof eruption: Bulletin of Volcanology, v. 82, no. 12, 21 p., https://doi.org/10.1007/s00445-019-1344-3. 
Waythomas, C.F., Loewen, M., Wallace, K.L., Cameron, C.E., and Larsen, J.F., 2020, Geology and eruptive history of Bogoslof volcano: Bulletin of Volcanology, v. 82, no. 14, 23 p., https://doi.org/10.1007/s00445-019-1352-3.
Werner, C., Kern, C., and Kelly, P.J., 2020, Chemical evaluation of water and gases collected from hydrothermal systems located in the central Aleutian arc, August 2015: U.S. Geological Survey Scientific Investigations Report 2020-1029, 35 p., https://doi.org/10.3133/sir20201029.

\section{Analog-to-Digital Conversion of Monitoring Sites in Alaska}
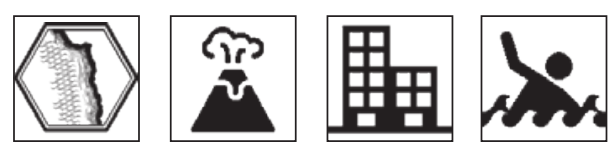

This project converts and upgrades all remaining legacy analog equipment in the (AVO geophysical network to enhance monitoring capabilities and meet regulatory requirements. New ground-based instrumentation includes seismometers, infrasound sensors, and web cameras, and significantly improves AVO's ability to detect unrest, forecast eruptive activity, and issue timely alerts of volcano hazards. The upgrades address needed replacement of aging analog equipment with modern digital instruments and radios, as well as refurbishment of existing digital equipment at some sites with more robust digital installations. This work, which was mandated by requirements set forth by the National Telecommunications and Information Administration to vacate radio frequencies used by older analog equipment, has substantially improved the data quality at new digital stations installed in 2019. The new data also will be of value for other monitoring programs, such as those focused on earthquakes and tsunamis.

In 2019, upgrades were completed successfully at 45 stations and focused on networks around Adak (Gareloi, Tanaga, Kanaga, and Great Sitkin) and on Atka Island. In light of COVID-19, we had to make changes to the scheduled 2020 work because of timing, logistical constraints, and our desire to protect crews and the remote communities in the Aleutian Island chain. We have postponed planned work in the far western Aleutians, hoping to accomplish it in 2021. The vessel-based field work in 2020 focuses on maintenance and upgrades in Cook Inlet, on the Alaska Peninsula, and as far west as Dutch Harbor. This change to our schedule decreases from 24 to 13 the planned number of analog-to-digital upgrades for 2020.

\begin{tabular}{ccc}
\hline Time frame & Budget & Project partners \\
\hline Ongoing & $>\$ 1,000,000$ & University of Alaska Fairbanks; Alaska Division of Geological and Geophysical Surveys \\
\hline
\end{tabular}

\section{Contact}

Michelle Coombs, Volcano Science Center, mcoombs@usgs.gov, (907) 250-3984 


\section{Sea Ice Loss, Coastal Flooding, and Erosion}

\section{Alaska Coastal Processes and Hazards}
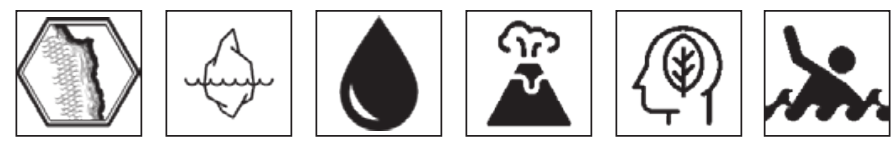

The current warming trend across the Arctic and Alaska is substantially reducing sea ice extent, causing permafrost thaw, and changing climatic and oceanographic patterns. Coastal impacts resulting from these changes are multi-dimensional and include rapid coastal erosion that threatens village and facility (for example, oil and gas) infrastructure, ecosystem stability, and critical cultural and social networks and needs. Parallel to the negative impacts are new and emerging opportunities related to increasing accessibility and economic opportunities. The objectives of this project are to identify hazards; quantify risk; and evaluate impacts of past, present, and future coastal processes on infrastructure, biology, and people along the Alaskan coast, including the Arctic. The methods integrate field studies and numerical modeling and include (1) developing new methods for collection of spatially varying permafrost thermal exchange; (2) nearshore bathymetry and elevation data; and (3) modeling tools for better characterizing future flood hazards, bluff recession, and barrier island landscape change.

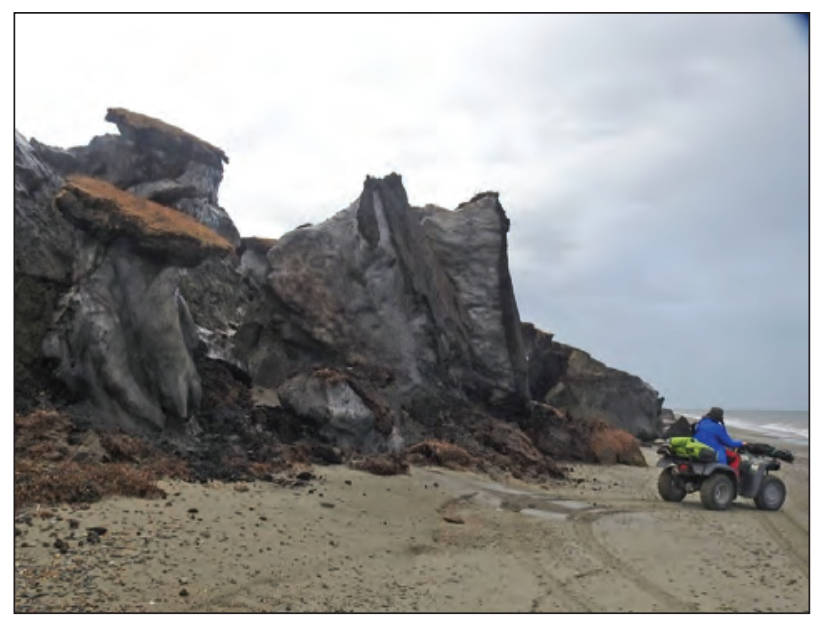

Permafrost bluff erosion following a series of coastal storms and prolonged time of anomalously high air temperatures, on Barter Island, Beaufort Sea, northern Alaska, 2019.

\begin{tabular}{ccc}
\hline Time frame & Budget & Project partners \\
\hline FY2020-ongoing & $\$ 100,000-\$ 499,000$ & $\begin{array}{c}\text { Alaska Division of Geological and Geophysical Surveys (in kind); University of Alaska } \\
\text { Anchorage (UAA) and Fairbanks (UAF) (in kind) }\end{array}$ \\
\hline
\end{tabular}

\section{Contacts}

Li Erikson, Pacific Coastal \& Marine Science Center, lerikson@usgs.gov, 831-460-7563

Ann Gibbs, Pacific Coastal \& Marine Science Center, agibbs@usgs.gov, 831-460-7540

Ferdinand Oberle, Pacific Coastal \& Marine Science Center, foberle@usgs.gov, 831-460-7589

\section{Recent Publication}

Oberle, F.K.J., Gibbs, A.E., Richmond, B.M., Erikson, L.H., Waldrop, M.P., and Swarzenski, P.W., 2019, Towards determining spatial methane distribution on arctic permafrost bluffs with an unmanned aerial system: SN Applied Sciences, v. 1, no. 236, 9 p., https://doi.org/10.1007/s42452-019-0242-9.

\section{Project Links}

https://www.usgs.gov/centers/pcmsc/science/climate-impacts-arctic-coasts https://www.usgs.gov/natural-hazards/coastal-marine-hazards-and-resources/science/climate-change-us-arctic-ocean-margins 


\section{Building an Operational System to Forecast Potential Flood Hazards in Unalakleet, Alaska}
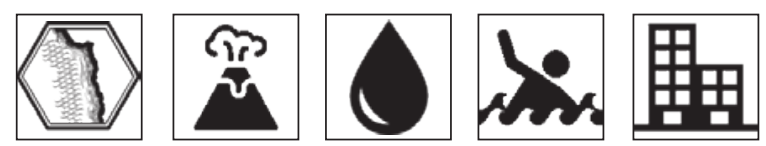

Like many coastal communities of Alaska, the village of Unalakleet is vulnerable to marine flooding during large storms. Storm surge in Norton Sound typically occurs in the fall and winter months when the coastline is protected by shorefast ice. However, warming trends in the Arctic have resulted in reduced ice coverage and increased occurrence of wave events affecting coasts. Two video cameras were installed by USGS in collaboration with the Alaska Division of Geological and Geophysical Surveys and village authorities to better understand wave and water-level dynamics in Norton Sound. Every 30 minutes during daylight hours, the cameras collect snapshots and videos for 10 minutes, which are posted online. These and other images are then used to observe and quantify coastal processes such as wave run-up, development of rip channels, bluff erosion, and movement

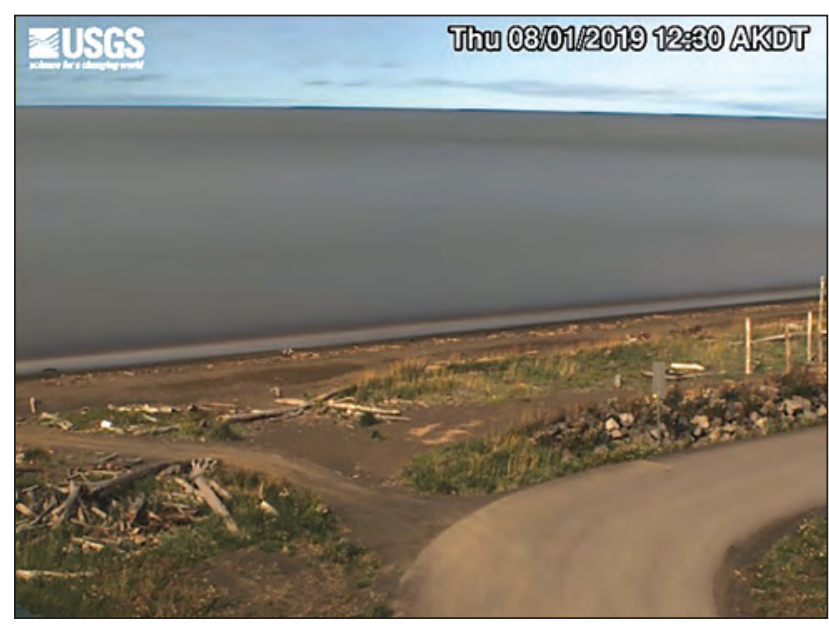

Looking westward over Norton Sound from two video cameras atop a windmill tower in Unalakleet, western Alaska. of sandbars and ice floes. The USGS plans to install similar systems in other U.S. locations (two video cameras temporarily overlooked the Beaufort Sea coast from atop the coastal bluff of Barter Island near Kaktovik in 2018). The knowledge gained from these camera systems will improve computer-derived simulations of shoreline change that communities can use to plan for sea-level rise, changing storm patterns, and other threats to coasts. In collaboration with NOAA, the overriding USGS goal is to develop a real-time system to provide approximately 6-day forecasts of total water level and flood potentials from the analysis of astronomic tides, storm surge, and wave runup. Toward that end, about 90 kilometers of bathymetry track-line data were collected in the inlet and estuary and along the open coast extending about 1.2 kilometers north and south of the inlet and about 1.5 kilometers offshore.

\begin{tabular}{ccc}
\hline Time frame & Budget & Project partners \\
\hline FY2019-ongoing & $<\$ 100,000$ & $\begin{array}{c}\text { Alaska Division of Geological and Geophysical Surveys; Native Village of Unalakleet; City of } \\
\text { Unalakleet; National Oceanic and Atmospheric Administration }\end{array}$ \\
\hline
\end{tabular}

\section{Contacts}

Rob Li Erikson, Pacific Coastal and Marine Science Center, lerikson@usgs.gov, (831) 460-7563

Ann Gibbs, Pacific Coastal and Marine Science Center, agibbs@usgs.gov, (831) 460-7540

\section{Project Link}

https://www.usgs.gov/centers/pcmsc/science/using-video-imagery-study-wave-dynamics-unalakleet?qt-science_center objects $=0 \#$ qt-science_center_objects 


\section{Wave and Hydrodynamic Observations and Modeling in the Nearshore Beaufort Sea}

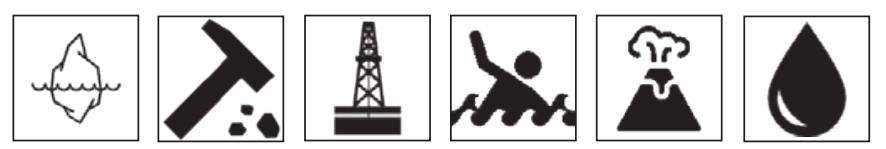

Renewed interest in nearshore oil exploration and production in the central Beaufort Sea has created a general need to advance understanding of the dynamic physical conditions in the Beaufort Sea coastal region. Specifically, the BOEM requires information on the potential impacts that present-day and future sea-ice and atmospheric conditions will have on waves, currents, and sedimentation rates, and ice pile-up events during the expected timeframe of the offshore Liberty Development Project (about 2020-50). Historical observational data were compiled and a coordinated field effort was completed in 2019 to better characterize the system and support model calibration and validation. USGS is developing a coupled wavehydrodynamic-sediment transport model to produce a 40 -year hindcast (1979-2019) and projection (2020-49) of waves, storm surge, and sediment transport potentials within Foggy Island Bay and greater Stefansson Sound.

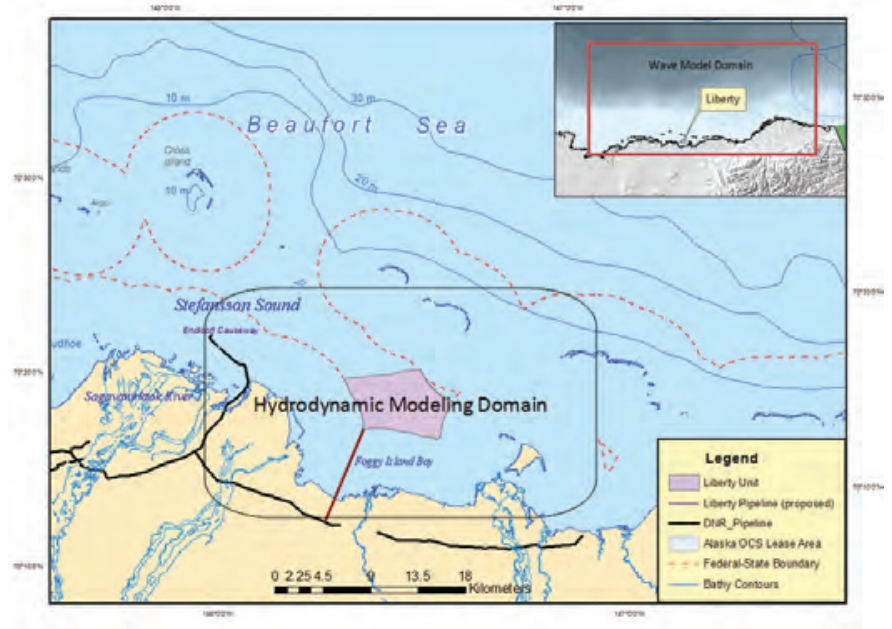

Proposed general location of Liberty Development Project with the study model domain, in Foggy Island Bay and Stefansson Sound area of the Beaufort Sea, on the north coast of Alaska. Figure source: https://aoos.org/foggy/.

\begin{tabular}{ccc}
\hline Time frame & Budget & Project partners \\
\hline FY2018-22 & $>\$ 1,000,000$ & $\begin{array}{c}\text { Bureau of Ocean Energy Management, University of Alaska Fairbanks, University of Alaska Anchorage, } \\
\text { Alaska Ocean Observing System, Axiom Data Science }\end{array}$ \\
\hline
\end{tabular}

\section{Contact}

Rob Li Erikson, Pacific Coastal and Marine Science Center, lerikson@usgs.gov, (831) 460-7563 


\section{National Assessment of Shoreline Change on the Coast of Alaska}
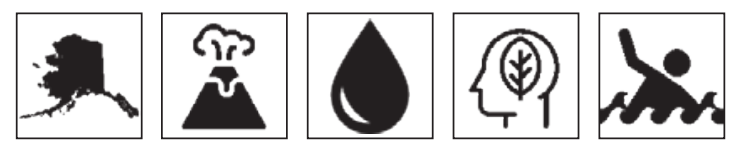

Coastal erosion is extensive in Alaska, threatening coastal communities, infrastructure and nearshore habitat. There is a need to determine rates and patterns of historical shoreline change along Alaska's coast to support longterm planning and decision-making to ensure sustainable coastal communities and ecosystems. As part of the USGS National Assessment of Shoreline Change and Alaska Coastal Processes and Hazards projects, USGS is quantifying rates and patterns of shoreline change. Objectives of the projects include developing and improving coastal-change assessments, quantifying rates, and supporting long-term planning and decision-making to ensure

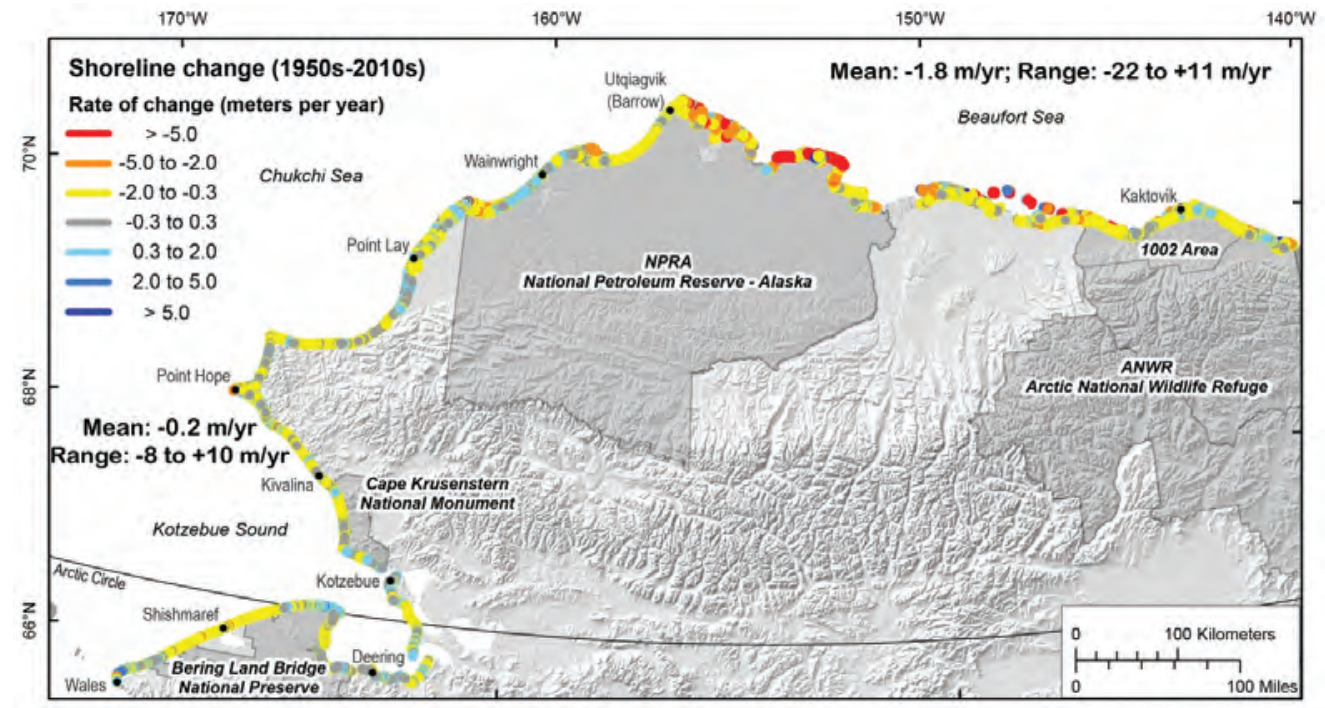

Color-coded shoreline change rates and key geographic locations on the north coast of Alaska. From Gibbs and Richmond (2015) and Gibbs and others (2019) (see "Recent Publications" at the end of this section). sustainable coastal economies, infrastructure, and ecosystems. Initial assessments are complete for the coast north of the Bering Strait to the U.S.-Canadian border. The next phase of analysis, started in FY20, extends the study area south to the YKD. Updated rates will be calculated as new shoreline datasets become available.

\begin{tabular}{ccc}
\hline Time frame & Budget & Project partners \\
\hline FY2019-ongoing & $\$ 100,000-\$ 500,000$ & Alaska Division of Geological and Geophysical Surveys \\
\hline
\end{tabular}

\section{Contact}

Ann Gibbs, Pacific Coastal and Marine Science Center, agibbs@usgs.gov, (831) 460-7540

\section{Recent Publications}

Gibbs, A.E., Ohman, K.A., Coppersmith, R., and Richmond, B.M., 2017, A GIS compilation of updated vector shorelines and associated shoreline change data for the north coast of Alaska, U.S. Canadian Border to Icy Cape: U.S. Geological Survey data release, https://doi.org/10.5066/F72Z13N1.

Gibbs, A.E., and Richmond, B.M., 2015, National assessment of shoreline change-Historical shoreline change along the north coast of Alaska, U.S.-Canadian border to Icy Cape: U.S. Geological Survey Open-File Report 2015-1048, 96 p., https://dx.doi.org/10.3133/ofr20151048.
Gibbs, A.E., and Richmond, B.M., 2017, National assessment of shoreline change-Summary statistics for updated vector shorelines and associated shoreline change data for the north coast of Alaska, U.S.-Canadian border to Icy Cape: U.S. Geological Survey Open-File Report 2017-1107, 21 p., https://doi.org/10.3133/ofr20171107.

Gibbs, A.E., Snyder, A.G., Richmond, B.M., 2019, National assessment of shoreline change - Historical shoreline change along the north coast of Alaska, Icy Cape to Cape Prince of Wales: U.S. Geological Survey Open-File Report 2019-1146, 52 p., https://doi.org/10.3133/ofr20191146.

Snyder, A.G., and Gibbs, A.E., 2019, National assessment of shoreline change-A GIS compilation of updated vector shorelines and associated shoreline change data for the north coast of Alaska, Icy Cape to Cape Prince of Wales: U.S. Geological Survey data release, https://doi.org/10.5066/P9H1S1PV. 


\section{Project Links}

https://www.usgs.gov/natural-hazards/coastal-marine-hazards-and-resources/science/climate-change-us-arctic-oceanmargins?qt-science_center_objects $=0 \#$ qt-science_center_objects

https://www.usgs.gov/centers/pcmsc/science/climate-impacts-arctic-coasts?qt-science_center_objects=0\#qt-science_ center_objects

https://www.usgs.gov/natural-hazards/coastal-marine-hazards-and-resources/science/national-assessment-coastal-change

\section{Wildfire}

\section{Ecosystems on the Edge-Changing Fire Regimes and Fire Behavior Impact on the Ecology and Management of Boreal and Tundra Systems}
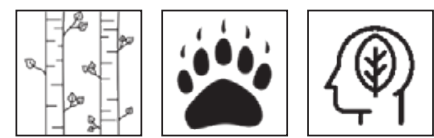

Wildfires that are uncharacteristically large, severe, or frequent can abruptly reorganize ecosystems, posing serious threats to ecosystem resilience and challenging management and conservation. High northern latitudes, including Alaska's boreal and sub-boreal forests and tundra, are warming approximately twice as fast the global average, driving broadscale shifts in vegetation communities, fuel availability, and wildfire characteristics. The objectives of this fire study are to provide partners and stakeholders with critical information on observed and potential future impacts of changing fire regimes and fire behavior on Alaska's ecosystems. The methods integrate field studies, in-place instrumentation and monitoring, ecosystem and fire models, geospatial and statistical modeling and analysis, and ecological theory to understand how, when, and where ecosystems on the edge will be affected by the synergistic interactions of climate and wildfires, and what may be done to buffer or mitigate negative impacts. Products include datasets that quantify fire characteristics and spatial patterns of fire across broad regions and ecosystems, manager-focused reports and other media that inform forward-looking management strategies, and peer-reviewed publications.

\begin{tabular}{ccc}
\hline Time frame & Budget & Project partners \\
\hline FY2016-20 & $\$ 100,000-\$ 500,000$ & $\begin{array}{c}\text { Northwest Boreal Landscape Conservation Cooperative, U.S. Geological Survey Ecosystems Program, } \\
\text { Joint Fire Science Program, National Park Service, U.S. Fish and Wildlife Service }\end{array}$ \\
\hline
\end{tabular}

\section{Contact}

Rachel Loehman, ASC, rloehman@usgs.gov, (505) 724-3664

\section{Recent Publications}

Keane, R.E., Loehman, R.A., and Holsinger, L.M., 2019, Selecting a landscape model for natural resource management applications: Current Landscape Ecology Reports, v. 4., p. 31-40, https://doi.org/10.1007/s40823-019-00036-6.

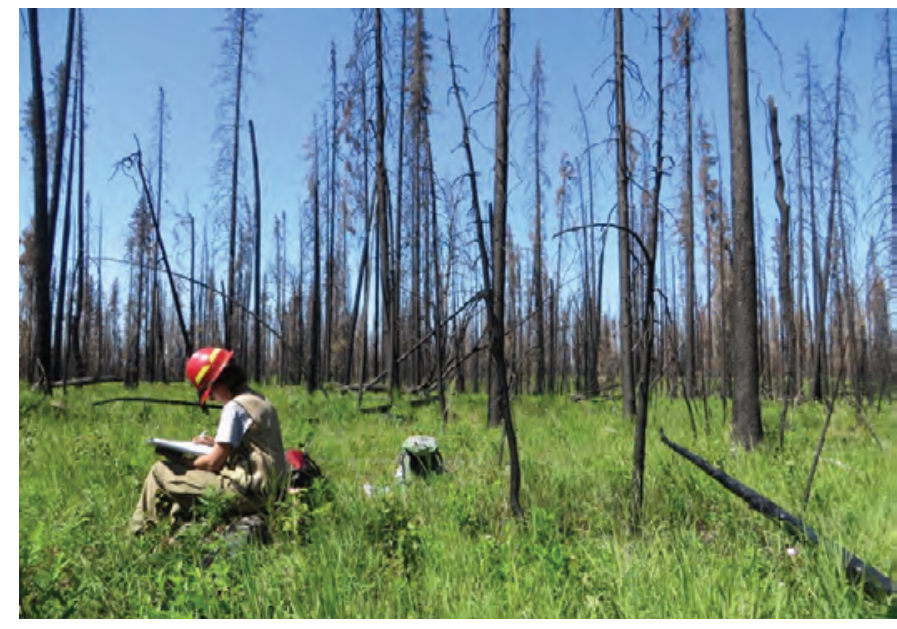

Fire ecologists recording post-fire information on tree mortality, fuel consumption, and vegetation communities to better understand and predict fire impacts, Kenai National Wildlife Refuge, Alaska. Photograph by Rachel Loehman, U.S. Geological Survey. 


\section{Project Link}

https://www.usgs.gov/centers/asc/science/ecosystems-edge-landscape-and-fire-ecology-forests-deserts-and-tundra?qt-science center_objects $=0 \#$ qt-science_center_objects

\section{COVID-19}

\section{Survey-COVID-19 Effects on Alaska Region}

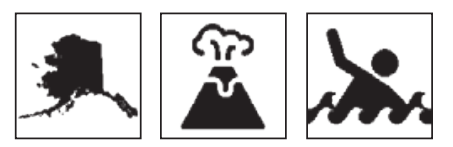

What are the variety of effects and most substantive impacts from COVID-19 on USGS activities and personnel specific to the work of the Alaska Region, and what can be done to mitigate them? To explore this question, the Alaska Regional Office developed and circulated a survey instrument open to all regional employees. One primary question asked whether 18 different potential effect categories pertained to each respondent, and if so, also asked for an estimate of the degree of change from pre-COVID 19 norms of practice, with choice options ranging from less than 10 percent, 10-25 percent, 26-50 percent, 51-75 percent, or more than 75 percent. All but two effect categories received positive responses indicating a magnitude of change greater than 75 percent. Survey responses indicated the following impacts:

- Routine interactions shifted to a virtual format and many field and lab projects originally scheduled in 2020 were cancelled or postponed.

- Staff focused resources more intently upon data analysis or document preparation and explored new methods of data sharing with others.

- Attention was diverted away from the normal work load to perform COVID-related tasks.

- External collaborations were adjusted to solve logistic problems or enhance coordination.

- Staff were affected by cancelled or postponed scientific workshops or conferences originally scheduled for 2020.

- Professional growth or external networking opportunities were reduced and staff experienced a sense of reduction in teamwork.

- Staff needed to troubleshoot loss or damage to equipment because of travel restrictions.

The survey also allowed for respondents to identify any additional COVID-19 effects that they experienced that were not otherwise covered by the 18 scripted "effect" categories and queried respondents to indicate how they may have developed proactive solutions to perform work during the pandemic. Finally, the survey invited suggestions about how management might steer adjustments in the future to make the pandemic situation more supportive for scientific/technical work. A total of 84 responses identified several key themes that have informed ongoing internal deliberations among regional management.

\section{Contact}

Dee Williams, Alaska Regional Office,dmwilliams@usgs.gov, (907) 786-7023 


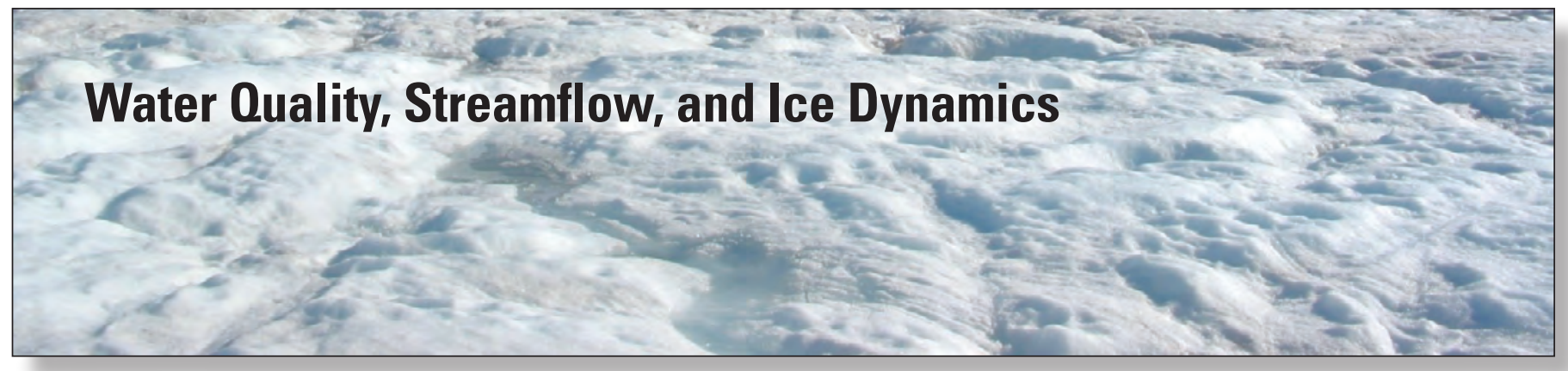

\section{Hydrologic Monitoring}

\section{Streamflow and Groundwater Monitoring}

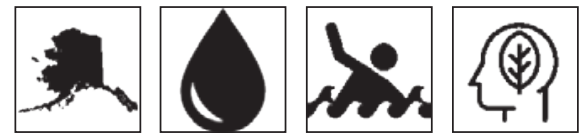

Nationwide, the USGS Groundwater and Streamflow Information Program supports the collection and delivery of streamflow and water-level information for more than 8,500 sites. The data are served online - most in near real time- to meet many diverse needs. The streamgages are operated and maintained by the USGS, but most are funded in partnership with one or more of about 1,400 Federal, State, local, and Tribal agencies or organizations. This unique cooperation results in nationally consistent and impartial data that also aids in local decision-making. Alaska has the lowest density of streamflow information stations in the Nation (112 streamflow sites in 2020, 64 of which also measure water temperature). The distribution of these streamgages is concentrated along the road system and near population centers, leaving many

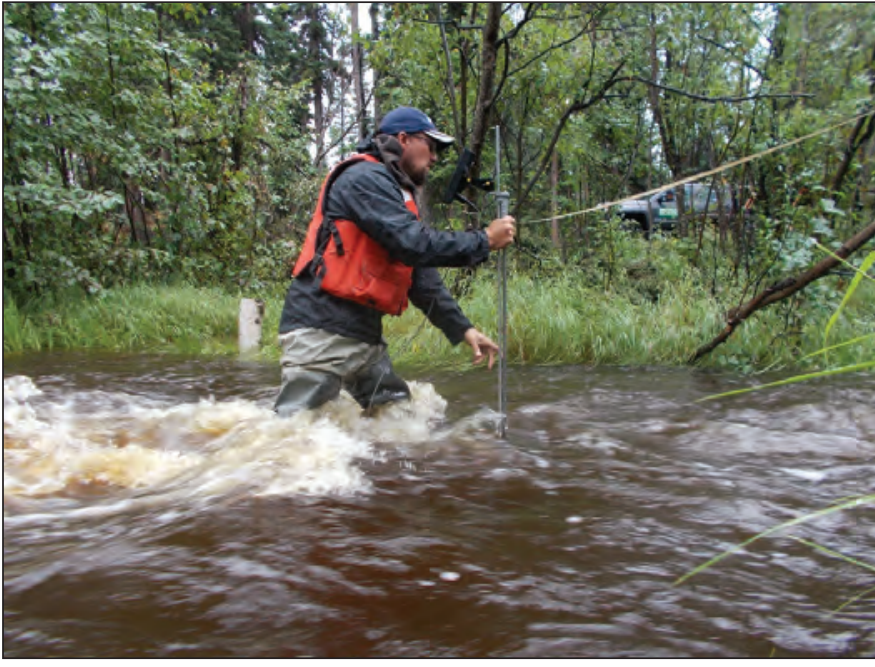

Measurement of discharge during high flow at June Creek near Clear, Alaska. Photograph by Heather Best, U.S. Geological Survey. areas of the State devoid of any hydrologic information.

Operation of a streamgage in Alaska is expensive; complex logistics, high personnel costs, and accessibility all contribute to the costs. The average cost of a USGS streamgage in Alaska is $\$ 30,000$ plus logistics, which vary considerably. Streamflow data are recorded at 15-minute intervals, stored on-site, and then transmitted to USGS offices every 1-4 hours, depending on the data relay technique used. Provisional data are relayed to USGS offices by satellite, telephone, and (or) radio telemetry; receive an automated quality-assurance check; and are available for viewing within minutes of arrival. All real-time data are provisional and subject to revision after a formal review process that includes computation of annual statistics.

\begin{tabular}{cc}
\hline Time frame & \multicolumn{1}{c}{ Project partners } \\
\hline Ongoing & $\begin{array}{c}\text { Alaska Department of Transportation; Alaska Department of Fish and Game; Alaska Energy Authority; U.S. Forest Service; } \\
\text { U.S. Fish and Wildlife Service; U.S. Army Corps of Engineers; and several municipalities and boroughs, hydropower } \\
\text { operators, and operating mines }\end{array}$ \\
\hline
\end{tabular}

\section{Contact}

Jeff Conaway, ASC, jconaway@usgs.gov, (907) 786-7041

Project Link

https://waterdata.usgs.gov/ak/nwis/rt 


\section{Continuous Monitoring and Baseline Assessment of Water Quality of Transboundary Alaskan Rivers}

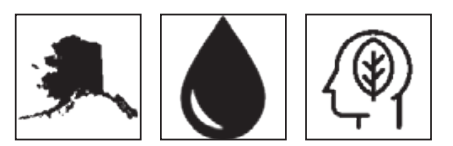

Multiple rivers, including the Salmon, Unuk, Stikine, Taku, and Alsek Rivers, originate in Canada and flow into Southeast Alaska. All five rivers support traditional, recreational, and commercial salmon fisheries. Active and proposed largescale mining activity in the Canadian parts of these watersheds poses a potential threat to the fisheries and traditional lifestyles in Alaska. The objectives of this study are to (1) assess the geology and mineralization potential of study area watersheds; (2) analyze retrospectively and collect new data to characterize the water, sediment, and biological quality of the rivers; and (3) establish partnerships with Tribes and government agencies to ensure that assessments meet the needs of Tribes and local stakeholders. Our methods include updated geologic mapping and sample reanalysis, biological sampling, and discrete water quality sampling. Information on streamflow and water-quality conditions collected hourly at downstream monitoring sites will be paired with periodically collected samples that are analyzed for concentrations of metals, nutrients, and major ions. In combination, these datasets will allow analysts to quantify loads of important water-quality constituents at daily, monthly, and annual time-steps. These data will serve as the basis for identifying potential changes in water-quality conditions resulting from future upstream mining activities.

\section{Contact}

Jeff Conaway, ASC, jconaway@usgs.gov, (907) 786-7041

\section{Project Link}

\begin{tabular}{|ccc|}
\hline Time frame & Budget & \multicolumn{1}{c}{ Project partners } \\
\hline $2019-23$ & $>\$ 1,000,000$ & $\begin{array}{l}\text { U.S. Geological Survey Water } \\
\text { Mission Area }\end{array}$ \\
\hline
\end{tabular}

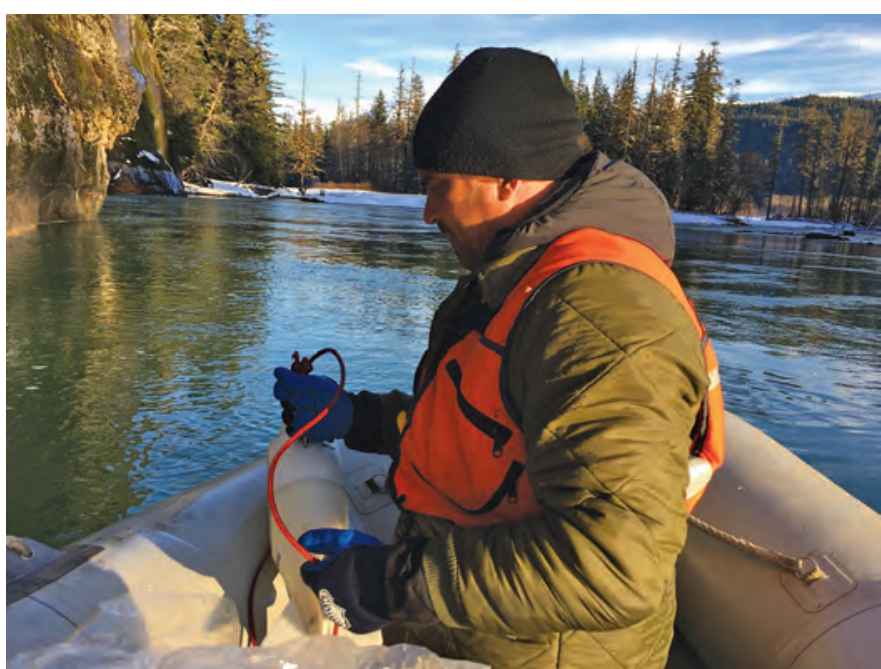

Water quality sampling on the Unuk River, Alaska. Photograph by Randy Host, U.S. Geological Survey objects $=0 \#$ qt-science_center_objects 


\section{Developing Remote Sensing Methods to Measure Streamflow in Alaskan Rivers}

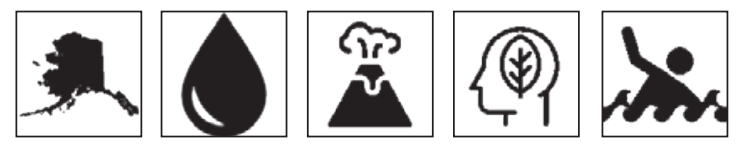

\begin{tabular}{|cc|}
\hline Time frame & Project partners \\
\hline 2016-ongoing & U.S. Army Corps of Engineers \\
\hline
\end{tabular}

Obtaining timely, accurate information on streamflow in Alaskan rivers is difficult because streamgages are relatively sparse. Even for established streamgages, the maintenance and periodic measurements involved in operating a streamgage are logistically challenging and can place personnel at risk, particularly during high water flows. The core objective of this study is to develop and test near-field remote sensing methods for measuring the river characteristics needed to estimate streamflow-flow velocity and channel geometry. In 2020, USGS scientists developed and tested a modular workflow to estimate surface-flow velocities from optical image time series acquired from a helicopter. The workflow was applied to image sequences acquired with a low-cost video camera and a high-resolution digital mapping camera. The accuracy of image-derived velocity estimates was assessed through comparison with direct field measurements made from a boat for field sites along the Knik, Matanuska, Susitna, Chena, Salcha, and Tanana Rivers in July 2019. Additionally, high-resolution lidar data were collected for each of these rivers. Lidar returns were used to measure water surface elevations and reach-scale water surface slopes. This research is significant because most Alaskan rivers do not have streamgages and efficient remote-sensing methods of measuring discharge could provide valuable streamflow information for water-resource management and flood-hazard mitigation. The long-term objective is to operationalize these methods so that remote sensing can become a viable tool for the USGS and other stakeholders to estimate surface-water flow velocities.
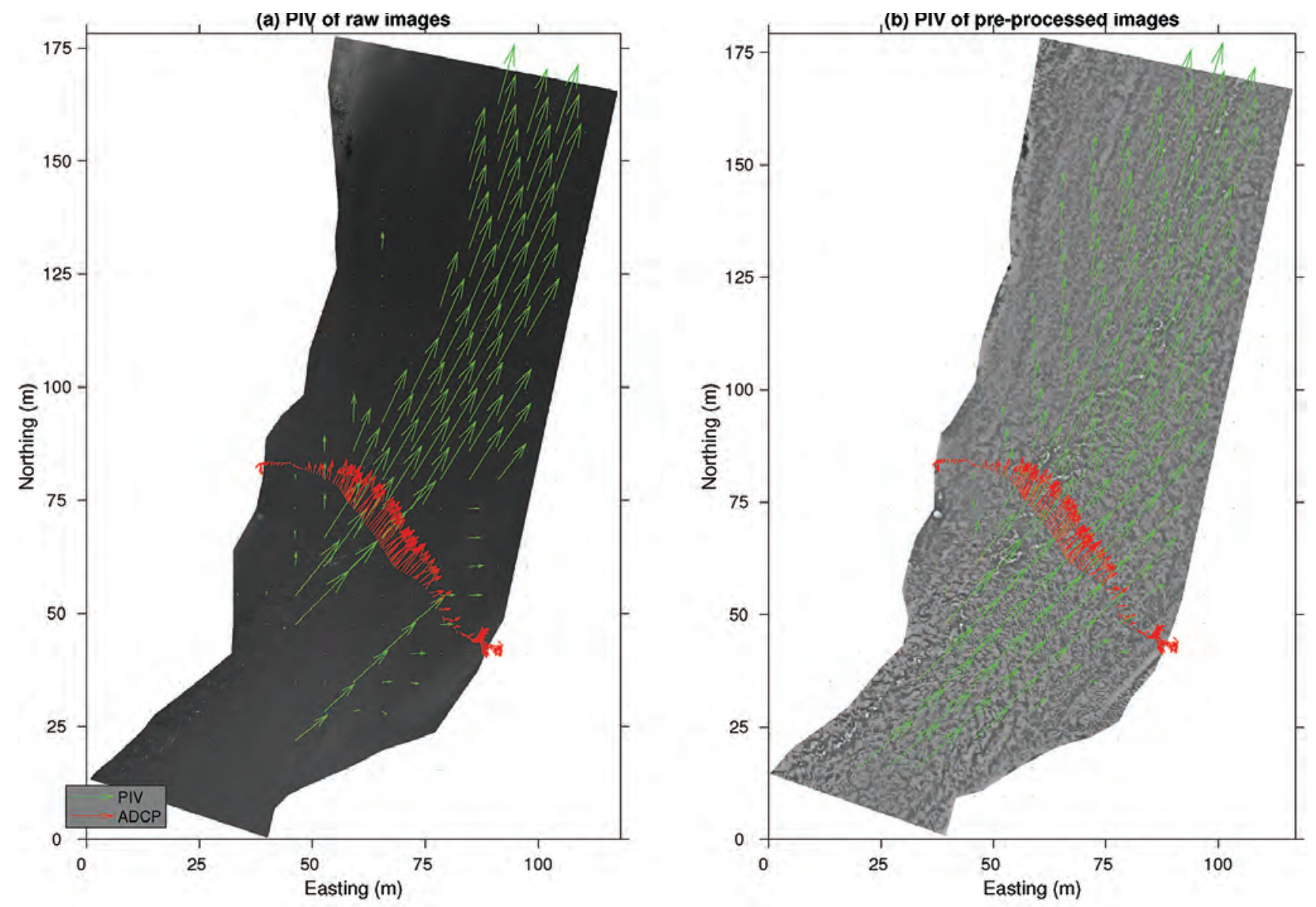

Comparison of image-derived, surface-flow velocity vectors derived from (a) raw images and (b) images preprocessed by the workflow described in Legleiter and Kinzel (2020). Image pixel size is 10 centimeters in both cases and the velocity vectors measured in the field with an Acoustic Doppler Current Profiler (ADCP) are overlain in red for comparison. m, meters; PIV, Particle image velocimetry. Source: Legleiter and Kinzel (2020) (see "Recent Publications" at the end of this section). 


\section{Contacts}

Paul Kinzel, Geomorphology and Sediment Transport Laboratory, pjkinzel@usgs.gov, (303) 278-7941

Carl Legleiter, Geomorphology and Sediment Transport Laboratory, cjl@usgs.gov, (307) 760-8369

\section{Recent Publications}

Kinzel, P.J., Legleiter, C.J., Nelson, J.M, Conaway, J.S., LeWinter, A.L., Gadomski, P.J, and Filiano, D.L., 2019, Near-field remote sensing of Alaska Rivers, in Proceedings of 2019 Federal Interagency Sedimentation and Hydrologic Modeling Conference (SEDHYD), Reno, Nevada, June 24-28, 2019, 10 p.

Legleiter, C.J., and Kinzel, P.J., 2020, Inferring surface flow velocities in sediment-laden Alaskan rivers from optical image sequences acquired from a helicopter: Remote Sensing, v. 12, no. 8, 28 p., https://doi.org/10.3390/rs12081282.

\section{Alaska Streambed Scour Monitoring and Modeling}

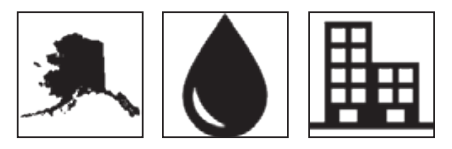

More than 60 percent of all bridge failures in the United States are caused by streambed scour, which is a result of complex hydraulic forces acting on streambeds during major flooding events. The costs associated with restoring damaged structures are substantial, but the indirect costs associated with the disruption of traffic often are even greater, especially in Alaska, where alternate travel routes between many cities do not exist. In cooperation with the Alaska Department of Transportation and Public Facilities (AKDOT\&PF), USGS has been researching streambed scour through scour monitoring, hydrodynamic modeling, and data collection during high flows for several decades. The current objectives of the streambed scour project are two-fold. The first objective is to monitor streambed elevations in real time at bridges coded as scour-critical and provide warnings to AKDOT\&PF during scour events. These methods

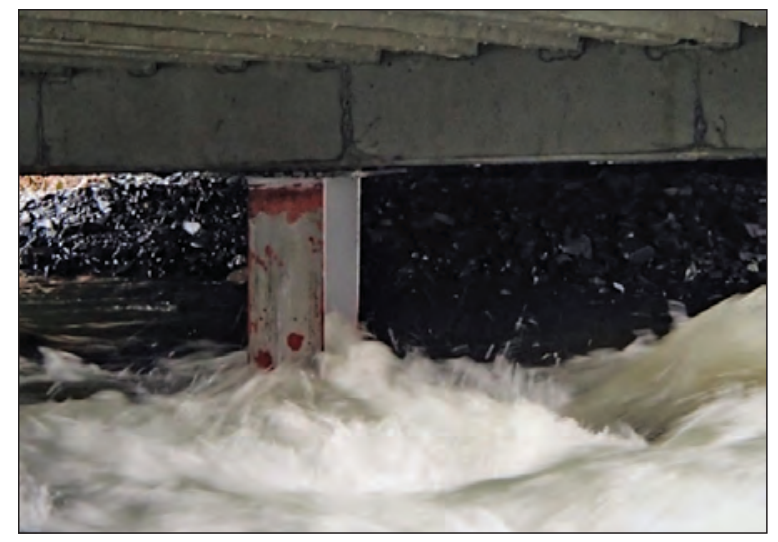

Pier hydraulics at Red Cloud River near Kodiak, Alaska, November 2018. Photograph by Paul Schauer, U.S. Geological Survey. include instrumenting bridges with sonars and stage sensors and collecting data during floods. The second objective is to predict hydraulic conditions that could lead to scour at bridges during floods using hydrodynamic models. This work allows State and Federal agencies to identify infrastructure that requires stream scour mitigation or annual monitoring for potential damage to infrastructure.

\section{Contact}

Robin Beebee, ASC, rbeebee@usgs.gov, (907) 786-7141

\section{Recent Publications}

Beebee, R.A., Dworsky, K.L., and Knopp, S.J., 2017, Streambed scour evaluations and conditions at selected bridge sites in Alaska, 2013-15: U.S. Geological Survey Scientific Investigations Report 2017-5149, 67 p., https://doi. org/10.3133/sir20175149.

Beebee, R.A., and Schauer, P.V., 2015, Streambed scour evaluations and conditions at selected bridge sites in Alaska, 2012: U.S. Geological Survey Scientific Investigations Report 2015-5154, 45 p., https://doi.org/10.3133/sir20155154.

\begin{tabular}{|ccc|}
\hline Time frame & Budget & Project partners \\
\hline $2017-21$ & $\$ 100,000-\$ 500,000$ & $\begin{array}{c}\text { Alaska Department of Transportation } \\
\text { and Public Facilities }\end{array}$ \\
\hline
\end{tabular}

Dworsky, K.L., and Conaway, J.S., 2019, Measurement of long-term channel change through repeated cross-section surveys at bridge crossings in Alaska: U.S. Geological Survey Open-File Report 2019-1028, 118 p., https://doi.org/10.3133/ ofr20191028.

\section{Project Link}

https://www.usgs.gov/centers/asc/science/streambedscour-bridges-alaska?qt-science_center_objects $=0 \#$ qt-science center_objects 


\section{Indigenous Observation Network 2.0 - Impacts of Environmental Change on the Yukon and Kuskokwim Watersheds}
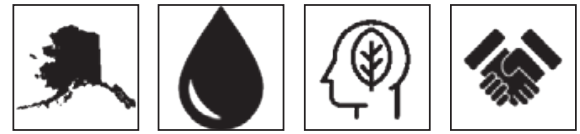

The Indigenous Observation Network 2.0-Impacts of Environmental Change on the Yukon and Kuskokwim Watersheds continues the Indigenous Observation Network (ION) long-term, community-based, water-quality monitoring project across Alaska and Western Canada. The ION 2.0 project will be led by the Yukon River Intertribal Watershed Council in partnership with the U.S. Geological Survey and the University of Alaska-Fairbanks. ION 2.0 expands the observation and monitoring program to include measurements of changes in permafrost depth at numerous of the long-term water quality monitoring sites. These changes occur because of thawing of the active layer driven by the changing Arctic climate. The ION project has shown that changes in major ion chemistry have occurred over three decades throughout the Yukon River watershed because of the thawing of discontinuous permafrost. This project involves significant co-production of knowledge with members of Indigenous communities and capacity building through training in sampling methods, and sample and data analysis.

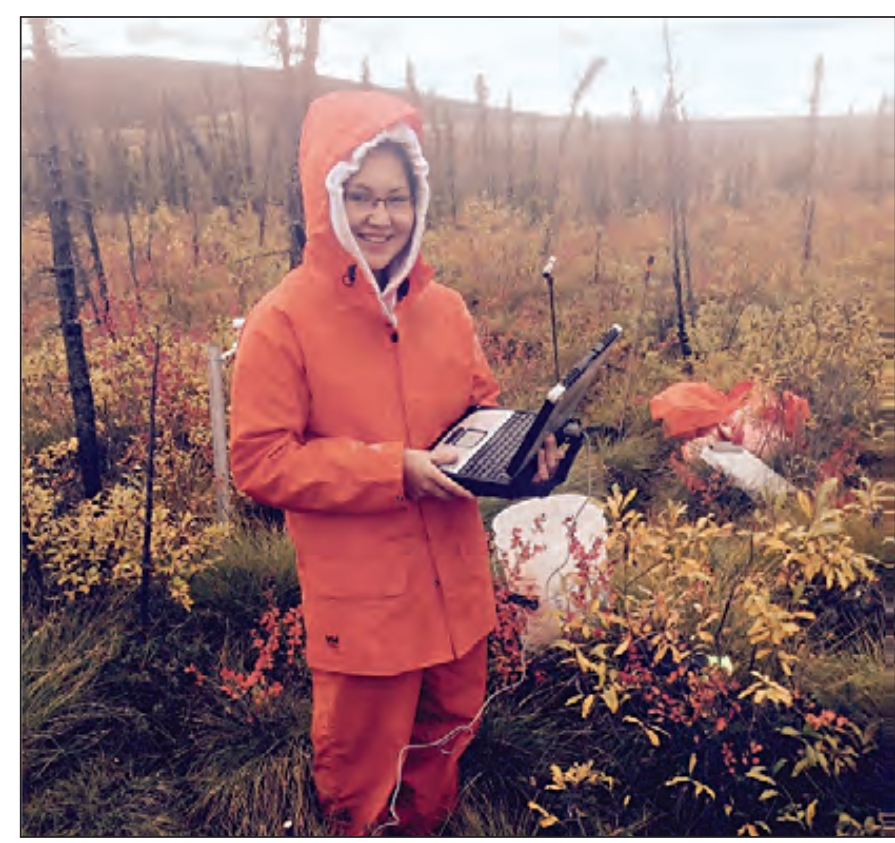

U.S. Geological Survey Student Intern in Support of Native American Relations (SISNAR) at Hess Creek Active Layer Network site, interior Alaska. Photograph by Ryan Toohey, U.S. Geological Survey.

\begin{tabular}{ccc}
\hline Time frame & Budget & Project partners \\
\hline $2019-22$ & $\$ 100,000-\$ 499,000$ & Yukon River Inter-Tribal Watershed Council, University of Alaska Fairbanks \\
\hline
\end{tabular}

\section{Contact}

Nicole Herman-Mercer, Decision Support Branch—Integrated Information Dissemination Division, Water Resources Mission Area,nhmercer@usgs.gov, (303) 236-5031

\section{Recent Publications}

Herman-Mercer, N.M., Antweiler, R.C., Wilson, N.J., Mutter, E.A., Toohey, R.C., and Schuster P.F., 2018, Data quality from a community-based, water-quality monitoring project in the Yukon River Basin: Citizen Science-Theory and Practice, v. 3, no. 2,13 p., http://doi.org/10.5334/cstp.123.

Toohey, R., Herman Herman-Mercer, N.M., Antweiler, R., Toohey, R., Mutter, E., Wilson, N., and Schuster, P.F., 2018, Achieving data credibility in community-based monitoring-A case study of water quality monitoring in the Yukon River Basin: Citizen Science-Theory and Practice, v. 3, no. 2.

\section{Project Link}

https://www.usgs.gov/centers/casc-sc/science/yukon-river-basin-indigenous-observation-network?qt-science_center_ objects $=0 \#$ qt-science_center_objects 


\section{Quantifying Groundwater and Aufeis and Their Contribution to Surface-Water Availability and Habitat in the Arctic National Wildlife Refuge, Alaska}
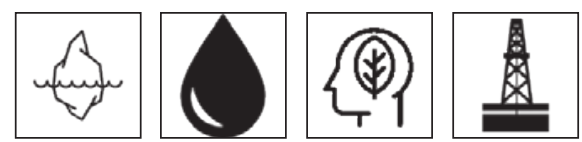

The North Slope of Alaska is a unique environment defined by continuous permafrost, abundant wildlife, and substantial industrial activity. Liquid water is a limited resource in this cold environment, with rivers providing important habitat and connections between terrestrial, freshwater, and marine ecosystems. Little is known about the relative contribution of precipitation and groundwater to rivers in this region, limiting our ability to properly manage water resources.

Our objectives include quantifying water sources, aquifer size, and groundwater ages on Alaska's North Slope and particularly in the 1002 region of the ANWR. Our methods include geochemical and remote sensing-based determinations of water sources and contributions to Arctic rivers, hydrological investigations of soil water and permafrost thaw potential, and isotopic age dating to determine aquifer properties and source areas. Our results will provide critical quantification of water resources, aiding managers in balancing ecological and industrial requirements in this extreme, water-limited environment.

\section{Contact}

Joshua Koch, ASC, jkoch@usgs.gov, (303) 817-5595

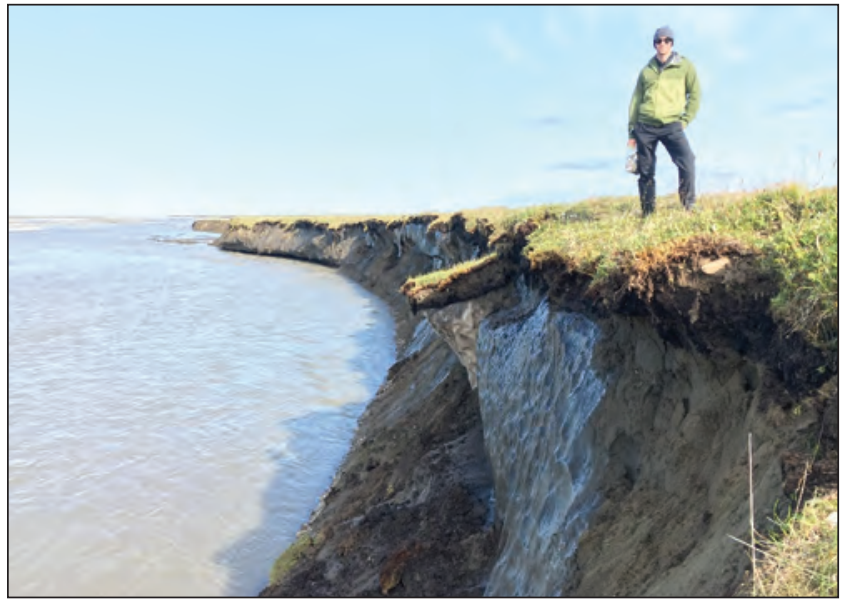

U.S. Geological Survey-National Science Foundation intern standing on a permafrost-rich bluff of the Canning River in the 1002 Region of the Arctic National Wildlife Refuge, North Slope of Alaska. Water samples and thermal imagery collected from a drone during this trip are being used to determine water sources to the river and to quantify water resources and fish habitat in this region. Photograph by Joshua Koch, U.S. Geological Survey.

\begin{tabular}{ccc}
\hline Time frame & Budget & Project partners \\
\hline $2019-22$ & $\$ 100,000-\$ 500,000$ & $\begin{array}{c}\text { U.S. Fish and Wildlife Service, } \\
\text { National Science Foundation }\end{array}$ \\
\hline
\end{tabular}




\section{Glaciers}

\section{U.S. Geological Survey Benchmark Glacier Mass Balance Project}

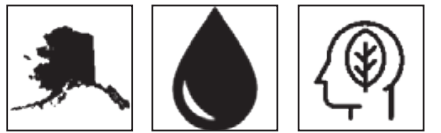

Glaciers are the defining feature of the physical landscapes in which they are located. Mountain glaciers profoundly affect the quality, quantity, and timing of runoff, local and regional ecosystems, global sea level, and land use. The primary objective of this project is to understand glacier mass change. Climate forcing has an immediate response in the form of seasonal mass gains and losses, and a delayed response of the glacier flow field that results in cumulative changes to glacier thickness and area. The methods use field-based measurements of winter accumulation, summer melt, and surface velocities, local weather stations, and remotely sensed changes in area and thickness. Reanalysis of legacy data increases our confidence that all five of the benchmark glaciers are losing mass, and the rate at which they are losing mass is increasing with time. Products include publicly available USGS data releases, summary data releases with the World Glacier Monitoring Service, and peer-reviewed publications.

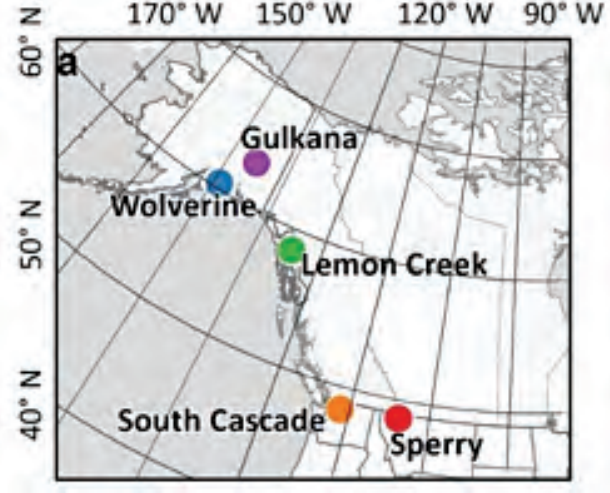

Locations of the five U.S. Geological Survey benchmark glaciers.

\begin{tabular}{|ccc|}
\hline Time frame & Budget & Project partners \\
\hline $2016-20$ & $\$ 500,000-\$ 1,000,000$ & U.S. Fish and Wildlife Service, National Science Foundation \\
\hline
\end{tabular}

\section{Contact}

Louis Sass, ASC, 1sass@usgs.gov, (907) 786-7460

\section{Recent Publications}

McNeil, C., O’Neel, S., Loso, M., Pelto, M., Sass, L., Baker, E., and Campbell, S., 2020, Explaining mass balance and retreat dichotomies at Taku and Lemon Creek Glaciers, Alaska: Journal of Glaciology, v. 66, no. 258, p. 530-542, https://doi.org/10.1017/jog.2020.22.

O’Neel, S., McNeil, C., Sass, L.C., Florentine, C., Baker, E.H., Peitzsch, E., McGrath, D., Fountain, A.G., and Fagre, D., 2019, Reanalysis of the US Geological Survey Benchmark Glaciers: long-term insight into climate forcing of glacier mass balance: Journal of Glaciology, v. 65 , no. 253, p. 850-866.

\section{Project Link}

https://www2.usgs.gov/landresources/lcs/glacierstudies/benchmark.asp 


\section{Wildfire Aerosols Determine Types of Past Burned Vegetation Archived in the Juneau Icefield}
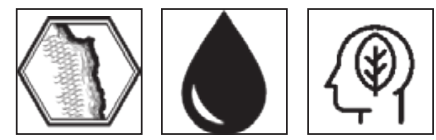

Over the past decade, increased fire activity has occurred in Alaska. Fires produce aerosols that can alter atmospheric and surface chemistry extending thousands of kilometers. Dark aerosols such as soot and black carbon can accelerate glacier melt when they are deposited on surface snow. The objective of this study is to determine if fires deposit aerosols on the surface of Southeast Alaskan glaciers, and if so, to identify the source of the fires. USGS Scientists drilled firn/ice cores across the Juneau Icefield in collaboration with the Juneau Icefield Research Program (https:// juneauicefield.org/) and chemi-
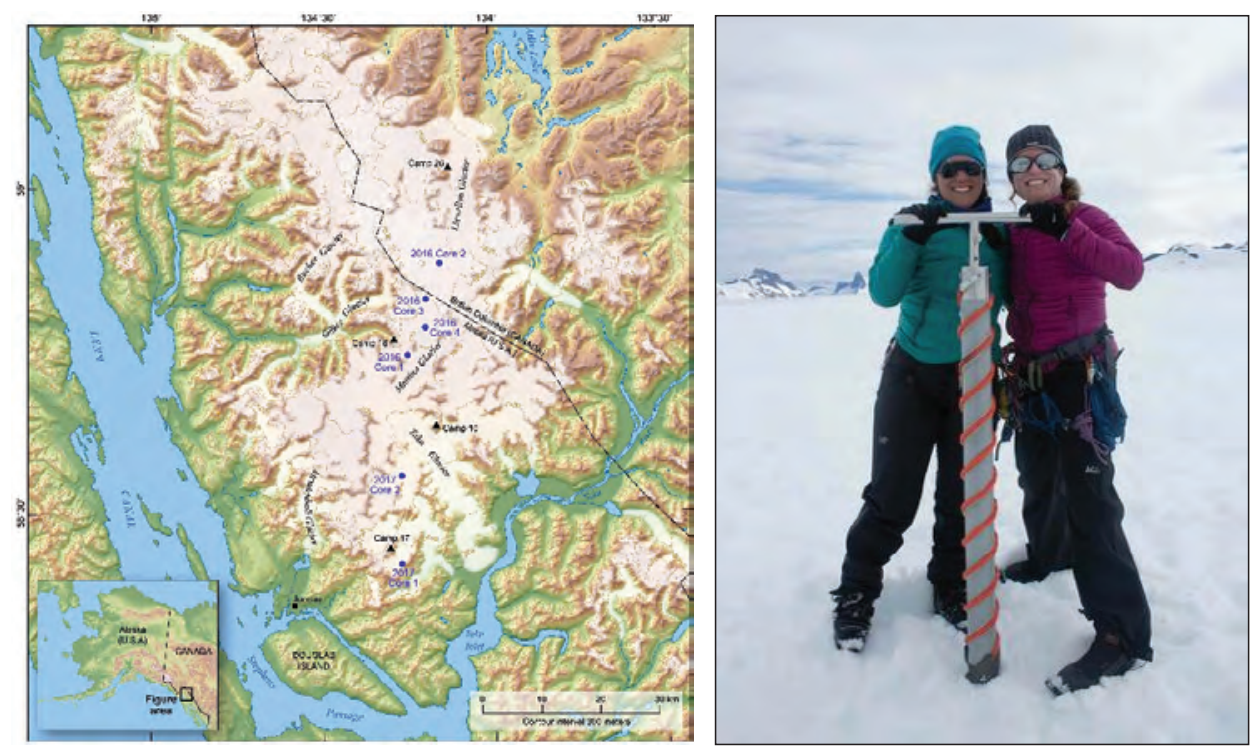

U.S. Geological Survvey scientists drilling transect of 7-9 meter firn cores to determine if recent fires are affecting the glacier surface, across the Juneau Icefield, Southeast Alaska. From Kehrwald and others (2020) (see "Recent Publications" at the end of this section).

cally analyzed the cores. A new analytical method was developed to determine past fire activity and types of burned vegetation. Using specific biomarkers in conjunction with remote sensing data, USGS scientists determined that Alaskan fires can deposit aerosols on the surface of the Juneau Icefield and that fires from as far away as East Asia also influence Southeast Alaskan glaciers. Although fires deposit dark aerosols on the glacier surfaces, combustion products from fossil fuel burning seem to have a greater impact on influencing the surface melt of the Juneau Icefield.

\begin{tabular}{ccc}
\hline Time frame & Budget & Project partners \\
\hline $2016-21$ & $\$ 100,000-\$ 400,000$ & Juneau Icefield Research Program (http://juneauicefield.org/mission) \\
\hline
\end{tabular}

\section{Contact}

Natalie Kehrwald, Geosciences and Environmental Change Science, nkehrwald@usgs.gov (763) 316-8302

\section{Recent Publications}

Jasmann, J.R., Kehrwald, N.M., Dunham, M.E., Ferris, D.G., Osterburg, E.C., Kennedy, J., and Barber, L.B., 2020, Using wildland fire tracer molecules to investigate fire frequency and vegetative combustion sources archived in the Juneau Icefield of Alaska: U.S. Geological Survey data release, https://doi.org/10.5066/P9DNAN1M.

Kehrwald, N.M., Jasmann, J.R., Dunham, M.E., Ferris, D.G., Osterberg, E.C., Kennedy, J., Havens, J., Barber, L.B., and Fortner, S.K., 2020, Boreal blazes-Biomass burning and vegetation types archived in the Juneau Icefield: Environmental Research Letters, v. 15, no. 8, 14 p., https://doi.org/10.1088/1748-9326/ab8fd2.

\section{Project Link}

https://www.usgs.gov/centers/gecsc/science/terrestrial-records-holocene-climate-change-fire-climate-and-humans?qt-science center_objects=0\#qt-science_center_objects 


\section{Permafrost}

\section{Arctic Biogeochemical Response to Permafrost Thaw (ABRUPT)}
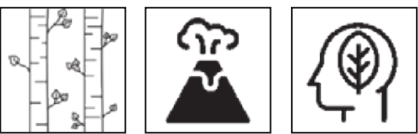

Warming and thawing of permafrost soils in the Arctic are expected to become widespread over the coming decades. Permafrost thaw changes ecosystem structure and function, resources for wildlife and society, and the ground stability that affects human infrastructure. Because permafrost soils contain about one-half of the global soil carbon pool, the magnitude of carbon losses from permafrost thaw is critically important to the global carbon cycle, known as the permafrost carbon feedback. The overall objective is to understand greenhouse gas (GHG) fluxes during the non-growing season from active-layer soils, permafrost, and supra-permafrost taliks in forests, bogs, and fens in Alaskan peatlands. Specifically, the study will (1) quantify the influence of talik formation and non-growing season processes on landscape-scale carbon dioxide and methane fluxes, (2) assess the quantity of old (millennialaged) carbon lost from thawing permafrost soils and quantify and regionalize that loss, (3) examine the extent to which permafrost near 0 degrees Celsius is releasing GHG, and (4) compare the vulnerability of carbon losses among soils of different formation histories.

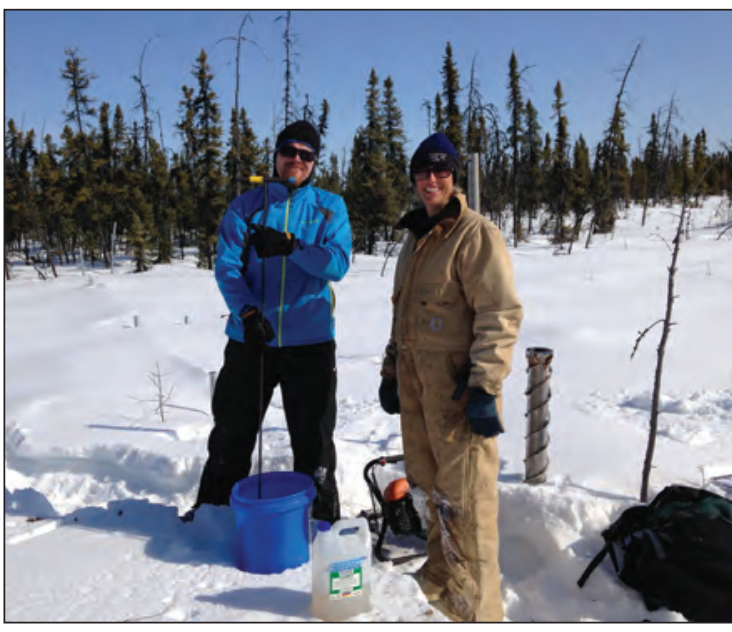

U.S. Geological Survey researchers taking frozen soil cores from the Alaska Peatland Experiment (APEX) to study carbon dynamics related to permafrost thaw. Photograph by Kristen Manies and Jack McFarland, U.S. Geological Survey.

\begin{tabular}{ccc}
\hline Time frame & Budget & \multicolumn{1}{c}{ Project partners } \\
\hline $2015-20$ & $\$ 500,000-\$ 1,000,000$ & $\begin{array}{c}\text { University of Alaska Fairbanks, California State University Northridge, University of Washington. } \\
\text { Partner contributions }\end{array}$ \\
\hline
\end{tabular}

\section{Contact}

Mark Waldrop, Geologic, Minerals, Energy, and Geophysics Science Center, mwaldrop@usgs.gov, (650) 714-9294

\section{Recent Publication}

Burkert, A., Douglas, T.A., Waldrop, M.P., and Mackelprang, R., 2019, Changes in the active, dead, and dormant microbial community structure across a Pleistocene permafrost chronosequence: Applied and Environmental Microbiology, v. 85, no. 7, 16 p., https://doi.org/10.1128/AEM.02646-18.

Cavallaro, N., Shrestha, G., Birdsey, R., Mayes, M.A., Najjar, R.G., Reed, S.C., Romero-Lankao, P., and Zhu, Z., eds., 2018, Second state of the carbon cycle report-A sustained assessment report: Washington, D.C., U.S. Global Change Research Program, 878 p., https://doi.org/10.7930/ SOCCR2.2018.

Creamer, C.A., Foster, A.L., Lawrence, C., McFarland, J., Schulz, M., and Waldrop, M.P., 2019, Mineralogy dictates the initial mechanism of microbial necromass association: Geochimica et Cosmochimica Acta, v. 260, p. 161-176, https://doi.org/10.1016/j.gca.2019.06.028
McFarland, J.W., Waldrop, M.P., Strawn, D.G., Creamer, C.A., Lawrence, C.R., and Haw, M.P., 2019, Biological and mineralogical controls over cycling of low molecular weight organic compounds along a soil chronosequence: Soil Biology and Biochemistry, v. 133, p. 16-27, https://doi. org/10.1016/j.soilbio.2019.01.013.

Natali, S.M., and others., 2019, Large loss of $\mathrm{CO}_{2}$ in winter observed across northern permafrost region: Nature Climate Change: v. 9, p. 852-857, https://doi.org/10.1038/s41558019-0592-8

Oberle, F.K.J., Gibbs, A.E., Richmond, B.M. Erikson, L.H., Waldrop, M.P, and Swarzenski, P.W., 2019, Towards determining spatial methane distribution on Arctic permafrost bluffs with an unmanned aerial system: SN Applied Sciences, v. 1, no. 236, 9 p., https://doi.org/10.1007/s42452019-0242-9.

Schütte, U.M.E., Henning, J.A., Ye, Y., Bowling, A., Ford, J., Genet, H., Waldrop, M.P., Turetsky, M.R., White, J.R., and Bever, J.D., 2019. Effect of permafrost thaw on plant and soil fungal community in a boreal forest-Does fungal community change mediate plant productivity response? Journal of Ecology, v. 107, no. 4, p. 1737-1752, https://doi.org/10.1111/1365-2745.13139. 


\section{Permafrost Mapping and Land-Cover Change}

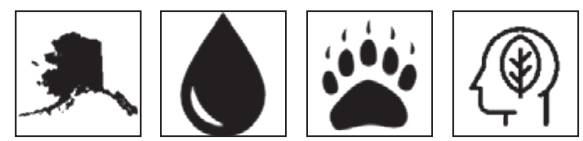

Given substantial changes in high-latitude systems, we seek to quantify and better understand the distribution and drivers of near-surface permafrost and associated land-cover change. The objectives of this study are to (1) improve baseline spatial information on near-surface permafrost and various types of historical land-cover change to improve modeling and understanding, and (2) quantify land-cover change probability of various kinds of change and their relation to environmental drivers. Regression and decision-tree methods have statistically captured complex interactions to spatially extend field observations and image interpretations to map near-surface permafrost and land-cover change at a 30-meter resolution. An overall mapping of nearsurface permafrost ( 85 percent) and accuracies of land-cover change (98 percent) in the overall map were strong. Results

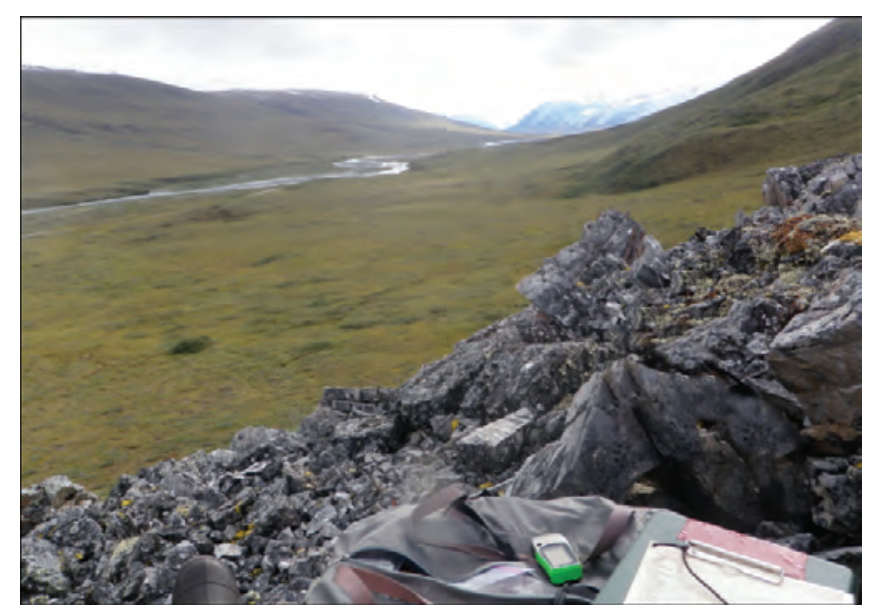

Permafrost sampling from talus slopes to riverbanks in Alaska's North Slope. Photograph by Bruce Wylie, U.S. Geological Survey. indicated that near-surface permafrost underlies 38 percent of mainland Alaska, with 16-24-percent potential reductions in area by the end of the 21st century. Thirteen percent of Alaska has had a change in land cover in the last 32 years. Current work is focusing on surface-water dynamics and association of land-cover change with permafrost and methane emissions.

\begin{tabular}{ccc}
\hline Time frame & Budget & Project partners \\
\hline $2008-20$ & $\$ 100,000$ & $\begin{array}{c}\text { National Aeronautics and Space Administration Arctic-Boreal Vulnerability Experiment, Bureau of Land } \\
\text { Management, U.S. Fish and Wildlife Service }\end{array}$ \\
\hline
\end{tabular}

\section{Contact}

Bruce Wylie, EROS Center,wylie@usgs.gov, (605) 594 6078; and Neal Pastick, EROS Center, njpastick@contractor.usgs. gov; (605) 594-2652

\section{Recent Publications}

Minsley, B.J., Pastick, N.J., Wylie, B.K., Brown, D.R.N., and Kass, M.A., 2017, Evidence for nonuniform permafrost degradation after fire in boreal landscapes: Journal of Geophysical Research-Earth Surface, v. 121, no. 2, p. 320-335, https://doi.org/10.1002/2015JF003781.

Pastick, N.J., Duffy, P., Genet, H., Rupp, S.T., Wylie, B.K., Johnson, K.D., Jorgenson, M.T., Bliss, N., McGuire, A.D., Jafarov, E.E., and Knight, J.F., 2017, Historical and projected trends in landscape drivers affecting carbon dynamics in Alaska: Ecological Applications, v, 77, no. 5, p. 1383-1402, https://doi.org/10.1002/eap.1538.

Pastick, N.J., Jorgenson, M.T., Goetz, S.J., Jones, B.M., Wylie, B.K., Minsley, B.J, Genet, H., Knight, J.F., Swanson, D.K., and Jorgenson, J.C., 2019, Spatiotemporal remote sensing of ecosystem change and causation across Alaska: Global Change Biology, v 25, no. 3, p. 1171-1189, https://doi.org/10.1111/gcb.14279.
Pastick, N.J., Jorgenson, M.T., Wylie, B.K., Nield, S.J., Johnson, K.D., and Finley, A.O., 2015, Distribution of nearsurface permafrost in Alaska-Estimates of present and future conditions: Remote Sensing of Environment, v. 168, p. 301-315, https://doi.org/10.1016/j.rse.2015.07.019.

Wylie, B.K., Pastick, N.J., Johnson, K.D., Bliss, N., and Genet, H., 2016, Soil carbon and permafrost estimates and susceptibility to climate change in Alaska, chap. 3 of Zhu, Z., and McGuire, A.D., eds., Baseline and projected future carbon storage and greenhouse-gas fluxes in ecosystems of Alaska: U.S. Geological Survey Professional Paper 1826, p. 53-76, https://doi.org/10.3133/pp1826.

\section{Project Link}

https://www.usgs.gov/centers/eros/science/ecosystem-performance-productivity-and-sustainability?qt-science_center_ objects $=0 \#$ qt-science_center_objects 


\section{Hydrologic Change in Permafrost Systems}
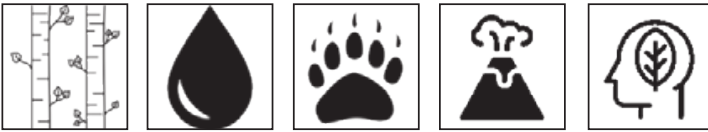

Permafrost exerts a major control on water movement and distribution across the landscapes of interior Alaska. As permafrost thaws, the subsurface becomes more permeable, allowing water and dissolved constituents to flow more freely and deeply below the surface. To better understand and quantify these complex dynamics, this project integrates subsurface measurement and modeling approaches to assess the vulnerability of permafrost in interior boreal Alaska and evaluate the impacts on hydrologic processes. Methods for subsurface characterization include borehole, ground-based noninvasive, and airborne geophysical techniques as well as soil sample collection for thermal and hydraulic property analyses. Data-informed hydrogeologic model simulations enable examination of the roles of climate change and landscape disturbance, such as wildfire, in influencing the rate and magnitude of permafrost thaw and consequent effects on

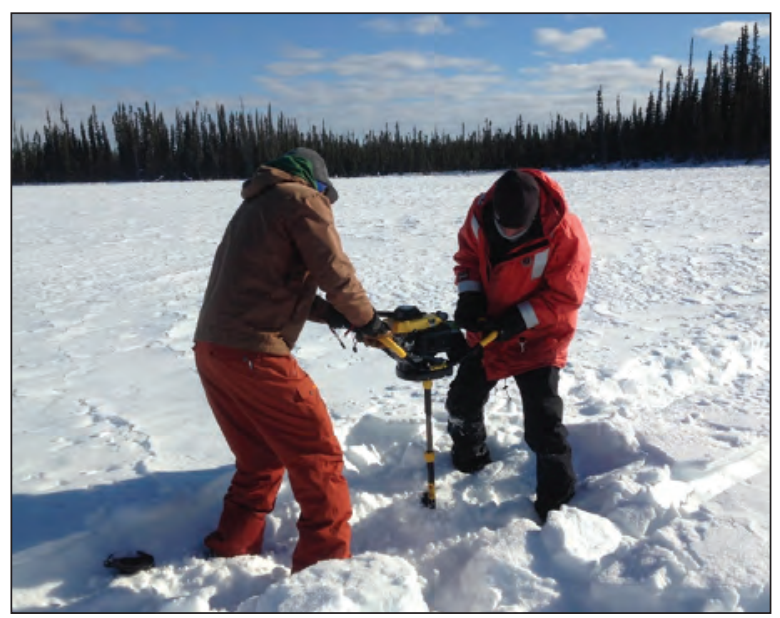

U.S. Geological Survey scientists coring lake ice to collect winter lake water chemistry samples, in the Yukon Flats, Alaska. Photograph by David Rey, U.S. Geological Survey. water and solute fluxes. Fundamental understanding of permafrost hydrology provides the underpinning for model predictions of streamflow, groundwater availability, and surface-water distribution in response to anticipated changes in air temperature, precipitation, wildfire, and vegetation. Projecting trajectories of water availability in interior Alaska is a primary objective of this effort.

\begin{tabular}{ccc}
\hline Time frame & Budget & Project partners \\
\hline $2016-21$ & $\$ 100,000-\$ 400,000$ & National Aeronautics and Space Administration \\
\hline
\end{tabular}

Contact

Michelle Walvoord, Earth System Processes Division, Water Mission Area, Lakewood, Colorado, walvoord@usgs.gov, (303) 236-4998

\section{Recent Publications}

Ebel, B., Koch, J., and Walvoord, M., 2019, Soil physical, hydraulic, and thermal properties in interior Alaska, USA-Implications for hydrologic response to thawing permafrost conditions: Water Resources Research, v. 55, no. 5, p. 4427-4447, https://doi.org/10.1029/2018WR023673.

Rey, D., Walvoord, M., Ebel, B., Minsley, B., Voss, C., and Singha, K. 2020, Wildfire-initiated talik development exceeds current thaw projections - Observations and models from Alaska's continuous permafrost zone: Geophysical Research Letters, v. 47, no. 15, 11 p., https://doi.org/10.1029/2020GL087565.

Rey, D.M., Walvoord, M., Minsley, B., Rover, J., and Singha, K. 2019. Investigating lake-area dynamics across a permafrostthaw spectrum using airborne electromagnetic surveys and remote sensing time-series data in Yukon Flats, Alaska: Environmental Research Letters, v. 14, no. 2, https://doi.org/10.1088/1748-9326/aaf06f.

Tank, S., Vonk, J., Walvoord, M., McClelland, J., Laurion, I., and Abbott, B., 2020, Landscape matters—Predicting the biogeochemical effects of permafrost thaw on aquatic networks with a state factor approach: Permafrost and Periglacial Processes, v. 31, no. 3, p. 358-370, https://doi.org/10.1002/ppp.2057. 


\section{Mercury and Carbon Dynamics in the Environment}
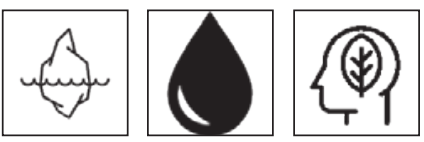

Changing climate in northern regions is causing permafrost to thaw with major implications for the global mercury $(\mathrm{Hg})$ cycle. Before the publication of this research, the storage of $\mathrm{Hg}$ in permafrost was not quantified. Thus, the research objective was to determine how much $\mathrm{Hg}$ is frozen in Northern Hemisphere permafrost soils. Standard soil analysis methods were used to measure sediment total mercury, bulk density, soil moisture and carbon-14 dating. Elevated precautions were taken to minimize $\mathrm{Hg}$ contamination of the soil samples. Our results estimate that these regions contain 1,656 \pm 962 gigagrams $(\mathrm{Gg}) \mathrm{Hg}$, of which $793 \pm 461$ $\mathrm{Gg} \mathrm{Hg}$ is frozen in permafrost. Permafrost soils store nearly twice as much $\mathrm{Hg}$ as all other soils, the ocean, and the atmosphere combined, and this $\mathrm{Hg}$ is vulnerable to release as permafrost thaws over the next century. Existing estimates greatly underestimate $\mathrm{Hg}$ in permafrost soils, indicating a need to reevaluate the role of the Arctic regions in the global $\mathrm{Hg}$ cycle.

\section{Contact}

Paul F Schuster, Water Mission Area, Earth System Processes

Division, Boulder, Colorado, pschuste@usgs.gov, (303) 5413052

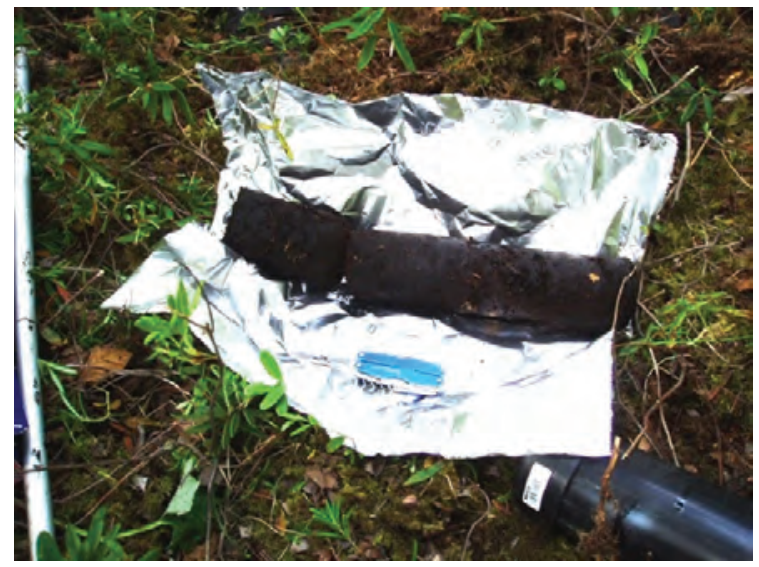

Permafrost core broken into segments, photographed, labeled, wrapped in plastic, encased in polyvinyl-chloride tubes, and then stored in a freezer until laboratory analysis. Photograph by Kim Wickland, U.S. Geological Survey.

\begin{tabular}{cc}
\hline Time frame & Project partners \\
\hline $2004-20$ & National Snow and Ice Data Center \\
\hline
\end{tabular}

\section{Recent Publication}

Schuster, P.F., Schaefer, K.M., Aiken, G.R., Antweiler, R.C., Dewild, J.F., Gryziec, J.D., and Zhang, T., 2018, Permafrost stores a globally significant amount of mercury: Geophysical Research Letters, v. 45, no. 3, p. 1463-1471, https://doi.org/10.1002/2017GL075571. 


\section{U.S. Geological Survey Climate and Permafrost Observing Network}
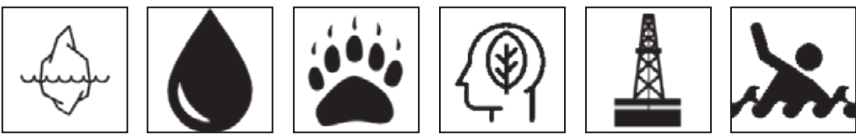

The USGS, BLM, and FWS each have an interest in tracking long-term climate patterns in the National Petroleum Reserve in Alaska (NPR-A) and the ANWR, where oil and gas exploration and development/potential development are actively occurring. This project exists to maintain the collection and interpretation of long-term climate and permafrost data from an existing network of observing stations, which the USGS has successfully operated since the late 1990s with the support of the BLM and FWS. Network sensors include air temperature, soil temperatures, relative humidity, precipitation, wind speed, wind direction, barometric pressure, snow depth, and solar radiation. In-season and long-term time

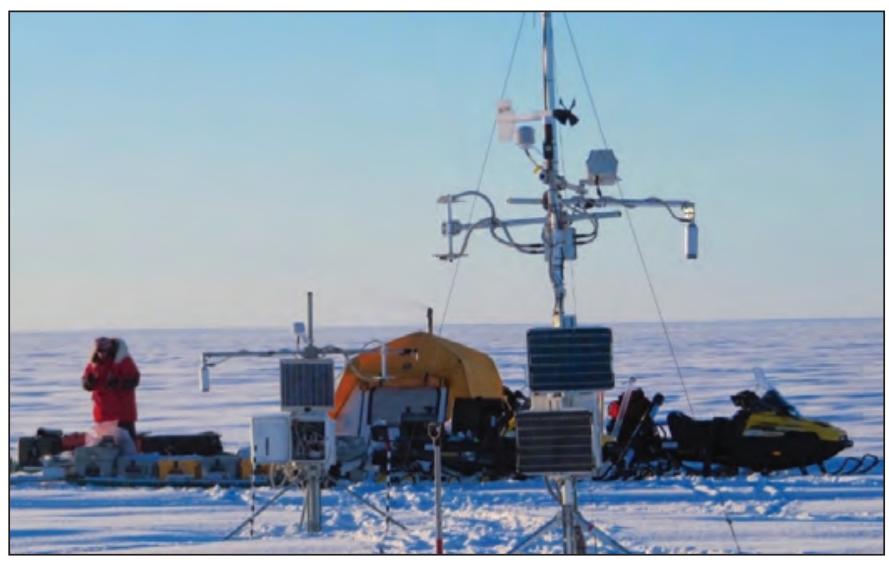

Climate station maintenance in Spring near Teshekpuk Lake, northern Alaska. Photograph by Frank Urban, U.S. Geological Survey.

series datasets from this program are essential to understanding natural environmental trends and variability in the Arctic, which contributes to the effectiveness of land-use planning, permitting, and monitoring. Additionally, many of the parameters observed at these stations are drivers of regional water balance and strongly influence storage and runoff patterns, information that is critical for the interpretation of hydrologic and biologic datasets. Fieldwork and data management are conducted by the USGS. Finalized data series will be released annually and archived within the Global Terrestrial Network for Permafrost and the Global Climate Observing System.

\begin{tabular}{ccc}
\hline Time frame & Budget & Project partners \\
\hline $2019-23$ & $\$ 100,000-\$ 500,000$ & Bureau of Land Management, U.S. Fish and Wildlife Service \\
\hline
\end{tabular}

\section{Contact}

Frank Urban, Geosciences and Environmental Change Science Center, furban@usgs.gov, (303) 236-4790

\section{Recent Publications}

Clow, G. 2015. Permafrost temperature data from a deep borehole array on the Arctic slope of Alaska (ver. 1): Boulder, Colorado, National Snow and Ice Data Center web page, accessed February 2, 2021, at https://doi.org/10.5065/D6N014HK. 


\section{Strategic Needs of Water in the Yukon (SNOWY)}
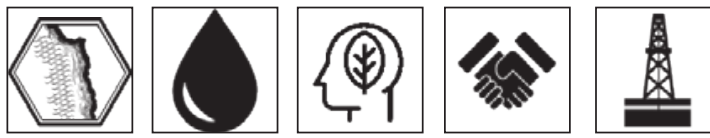

The YKD of western Alaska is undergoing significant environmental and societal change. Strategic Needs of Water on the Yukon (SNOWY) is a multi-disciplinary project with the objective to increase our understanding of the impacts of climate change on communities in this region. This increased understanding was accomplished using social science methods - semi-structured interviews and participatory mapping, in combination with traditional natural science techniques. Semistructured interviews focused on shifts in seasonal weather patterns and impacts on subsistence activities, and participatory mapping focused on the locations of seasonal subsistence resources. Results from the interviews highlighted differences in perception of climate change among younger and older generational cohorts. Participatory mapping results underscored

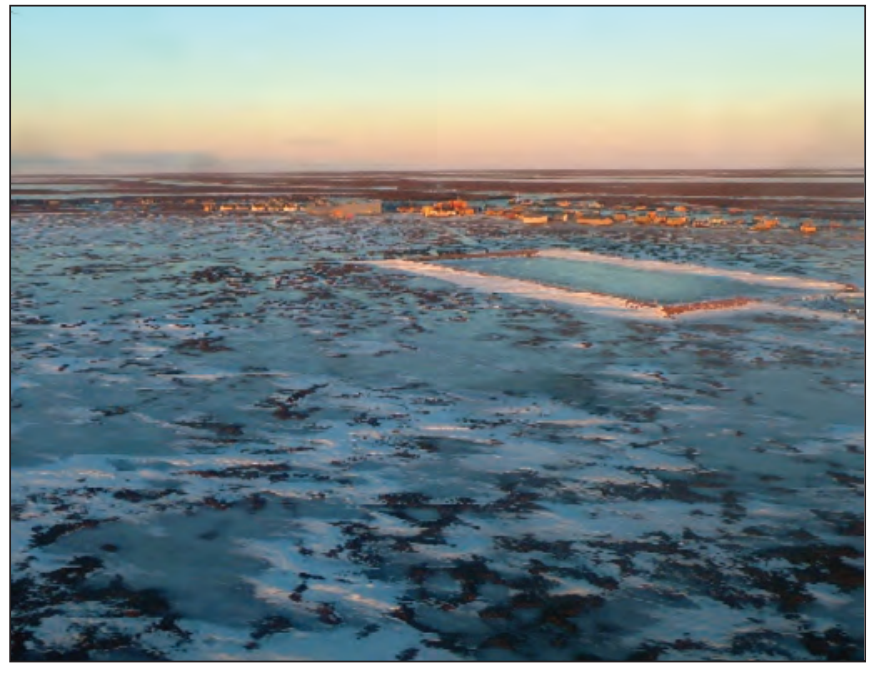

Winter view of village of Kotlik, western Alaska. Photograph by Kelly Elder, U.S. Forest Service. Used with permission. the potential vulnerability of subsistence systems in this region, particularly in light of recent socio-cultural change in these communities. Current research applying Indigenous Knowledge and observations to environmental change problems includes recent surveys to fill gaps in our understanding of wild berry productivity, abundance, and distribution, and community workshops to facilitate the documentation of locations and severity of impacts of landscape change in the region.

\begin{tabular}{ccc}
\hline Time frame & Budget & \multicolumn{1}{c}{ Project partners } \\
\hline 2012 -ongoing & $\$ 100,000-\$ 500,000$ & $\begin{array}{r}\text { The Yukon River Inter-Tribal Watershed Council, Colorado State University, U.S. Forest Service, } \\
\text { Kotlik Tribal Council, Chevak Traditional Council }\end{array}$ \\
\hline
\end{tabular}

\section{Contact}

Nicole Herman Mercer, Integrated Information Dissemination Division, Water Mission Area, nhmercer@usgs.gov, (303) 236-5031

\section{Recent Publications}

Herman-Mercer, N.M., and others, 2016, Changing times, changing stories - Generational differences in climate change perspectives from four remote indigenous communities in Subarctic Alaska: Ecology and Society, v. 21, no. 3, 19 p., http://dx.doi.org/10.5751/ES-08463-210328.

Herman-Mercer, N.M., and others, 2019, Vulnerability of subsistence systems due to social and environmental change-A case study in the Yukon-Kuskokwim Delta, Alaska: ARCTIC, v. 72, no. 3, p. 215-335, https://doi.org/10.14430/arctic68867.

Herman-Mercer, N.M., and Schuster, P.F., 2014, Strategic needs of water on the Yukon-An interdisciplinary approach to studying hydrology and climate change in the Lower Yukon River Basin: U.S. Geological Survey Fact Sheet 201-3060, 4 p, https://doi.org/10.3133/fs20143060.

\section{Project Link}

https:/toolkit.climate.gov/case-studies/yukon-delta-villages-document-baseline-environmental-data 


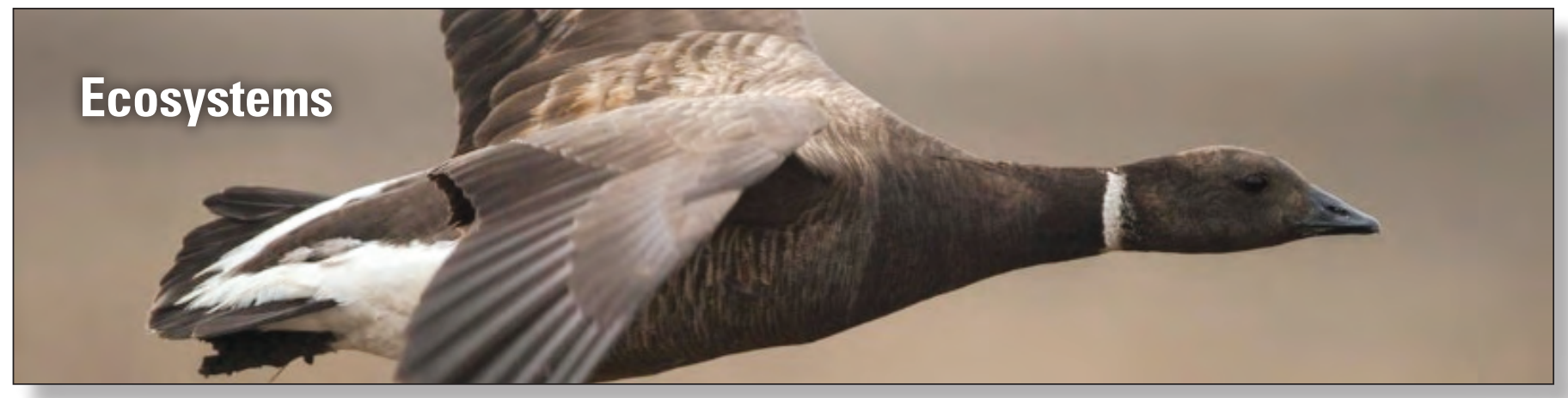

\section{Mammals}

\section{Polar Bear Distribution, Population Dynamics, Health, and Energetics Research}
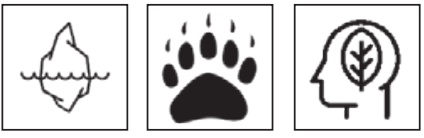

The polar bear is recognized worldwide as a vulnerable species because of loss of its required sea ice habitats. USGS science played a central role in informing the decision to list the polar bear as threatened under the Endangered Species Act in 2008. This science was founded in understanding gained from long-term studies of the southern Beaufort Sea (SB) population, 1 of 19 worldwide, and 1 of only 2 populations with long-term data. In these studies, the USGS documented a negative relation between length of the open water season over the continental shelf and population growth rate. Applying future sea ice conditions to the relation between sea ice availability and population growth rate allowed us to project a future trajectory of the population. We are monitoring the survival and habitat use of the SB population to determine whether the habi-

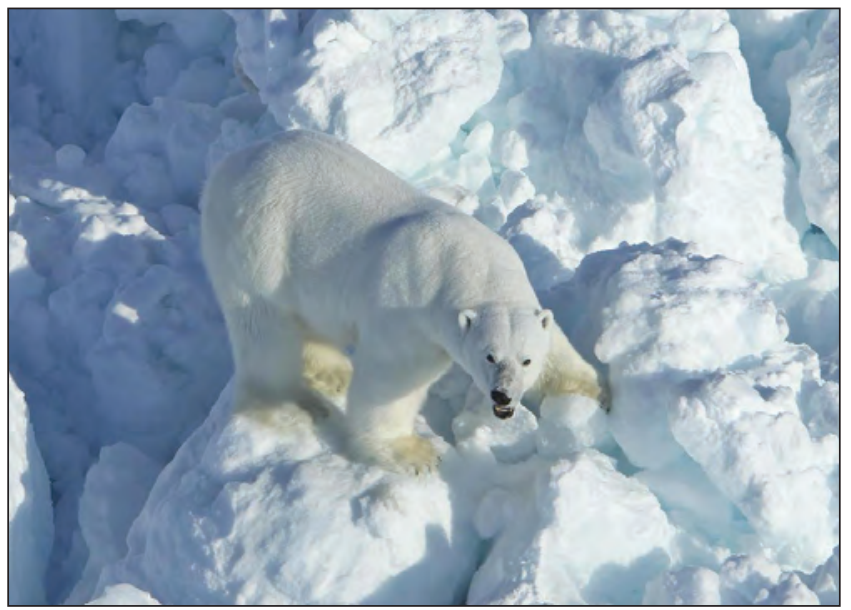

Polar bear on ice in the southern Beaufort Sea, off northern Alaska. Photograph by Mike Lockhart, U.S. Geological Survey. tat base for this population changes as projected and whether the population responds to those habitat changes as we projected in 2007. Information about how polar bears in this population respond to sea ice loss will inform management of the subsistence harvest, permitting of oil and gas activities in Alaska's coastal plain, and projections for the worldwide population.

\begin{tabular}{ccc}
\hline Time frame & Budget & \multicolumn{1}{c}{ Project partners } \\
\hline 1980s-ongoing & $>\$ 1000,0000$ & $\begin{array}{l}\text { U. S. Fish and Wildlife Service, Bureau of Land Management, Canadian Wildlife Service, North Slope } \\
\text { Borough, Inuvialuit-Inupiat Commission, Alaska Nannut Co-management Council, Alaska Eskimo } \\
\text { Whaling Commission, North Slope Communities, Industry }\end{array}$ \\
& &
\end{tabular}

\section{Contact}

Todd Atwood, ASC, tatwood@usgs.gov, (907) 786-7061

\section{Recent Publications}

Bourgue, J., Atwood, T.C., Divoky, G., Stewart, C., and McKinney, M.A., 2020, Fatty acid-based diet estimates suggest ringed seal remain the main prey of southern Beaufort Sea polar bears despite recent use of onshore food resources: Ecology and Evolution, v. 10, no. 4, p. 2093-2103, https://doi.org/10.1002/ece3.6043. 
Durner, G.M., Amstrup, S.C., Atwood, T.C., Douglas, D.C., Fischbach, A.S., Olson, J.W., Rode, K.D., and Wilson, R.R., 2020, Catalogue of polar bear (Ursus maritimus) maternal den locations in the Beaufort and Chukchi Seas and nearby areas, 1 910-2018: U.S. Geological Survey Data Series 1121, 12 p., including appendixes, https://doi.org/10.3133/ds1121.

[Supersedes U.S. Geological Survey Data Series 568.]

Durner, G.M., Douglas, D.C., and Atwood, T.C, 2019, Are polar bear habitat resource selection functions developed from 1985-1995 data still useful?: Ecology and Evolution, v. 9, no. 15, p. 8625-8638, https://doi.org/10.1002/ece3.5401.

Fry, T.L., Friedrichs, K.R., Atwood, T.C., Duncan, C., Simac, K.S., and Goldberg, T., 2019, Reference intervals for blood-based biochemical analytes of southern Beaufort Sea polar bears. Conservation Physiology, v. 7, no. 1, https://doi.org/10.1093/ conphys/coz040.

Lillie, K.M., Gese, E.M., Atwood, T.C., and Sonsthagen, S.A., Development of on-shore behavior among polar bears (Ursus maritimus) in the southern Beaufort Sea-Inherited or learned?: Ecology and Evolution, v. 8, no. 16, p. 7790-7799, https://doi.org/10.1002/ece3.4233.

Watson, S.E., Hauffe, H.C., Bull, M.J., Atwood, T.C., McKinney, M.A., Pindo, M., and Perkins, S.E., 2019, Global changedriven use of onshore habitat impacts polar bear faecal microbiota: ISME Journal, v. 13, p. 2916-2926, https://doi.org/10.1038/s41396-019-0480-2.

Wilson, R.R., and Durner, G.M., 2020, Seismic survey design and effects on maternal polar bear dens: The Journal of Wildlife Management, v. 84, no. 2, p. 201-212, https://doi.org/10.1002/jwmg.21800.

\section{Project Link}

https://www.usgs.gov/centers/asc/science/polar-bear-research 


\section{Pacific Walrus Research}

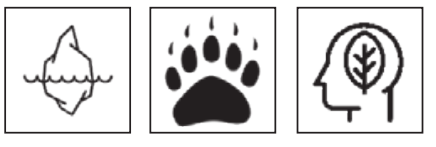

The Pacific walrus is one of four marine mammal species managed by the DOI. The ASC conducts long-term research on Pacific walruses to inform local, State, national, and international policy makers regarding conservation of the species and its habitat. The goal of current research is to refine and enhance models to forecast future walrus abundance and distribution resulting from changing Arctic conditions and human activities. The initial phase of current work began with the collection of population age structure data in three consecutive years (2013-15) from the Chukchi Sea during ship-based research cruises in collaboration with FWS and $A D F \& G$. These field efforts provided updated estimates of walrus population age structure, and these data, together with data from surveys repeated over the past four decades, provided current information on population status and trends. Current collaborations between USGS and FWS will also use these data to develop new statistical techniques to combine traditional mark-recapture with kinship data to provide more robust estimates of walrus population size. Ongoing and future work includes Unmanned Aircraft System (drone) population surveys of hauled out walruses in northwestern Alaska, assessments of walrus behavioral response to vessel interactions, and modeled linkages between future sea ice availability and walrus energetic requirements to population vital rates.

\begin{tabular}{cc}
\hline Time frame & \multicolumn{1}{c}{ Project partners } \\
\hline 2013-ongoing & $\begin{array}{c}\text { Alaska Department of Fish and Game, U.S. Fish and Wildlife Service, Bureau of Offshore Energy Management, Eskimo } \\
\text { Walrus Commission, North Slope Borough }\end{array}$ \\
\hline
\end{tabular}

\section{Contact}

Chadwick Jay, ASC, cjay@usgs.gov, (907) 786-7414

\section{Recent Publication}

Battaile, B.C. and Jay, C.V., 2020, Walrus haulout photographs near Pt. Lay Alaska, September 2014: U.S. Geological Survey data release, https://doi.org/10.5066/F7B27SB2.

\section{Project Link}

https:/www.usgs.gov/centers/asc/science/walrus-research

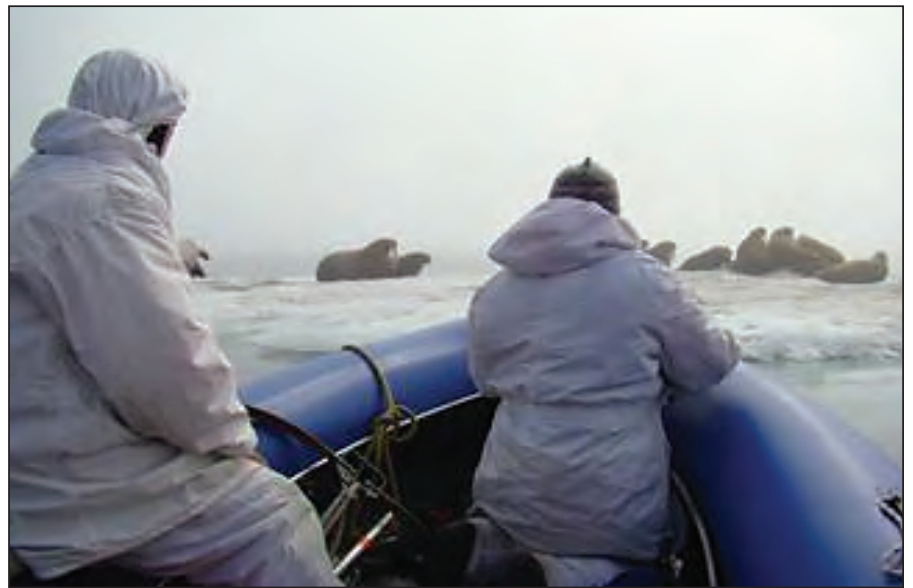

Scientists preparing to radio-tag walruses in the Chukchi Sea, northern Alaska, to track movements as sea ice is reduced in the region. 


\section{Nearshore Marine Ecosystem Research}
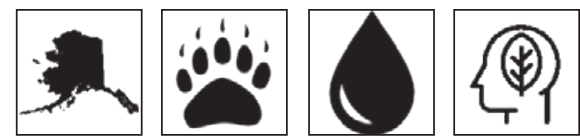

Nearshore ecosystems include many resources that are of high ecological, recreational, subsistence, and economic value. They also are subject to influences from a wide variety of natural and human-caused perturbations, which can originate in terrestrial or oceanic environments. Our research is designed to evaluate sources of variation in the nearshore and how they influence resources of high conservation interest. Our studies address community members at every trophic level, ranging from intertidal macroalgae and kelps to benthic invertebrates to top-level predators such as sea otters, black oystercatchers, and sea ducks. Key issues addressed by our program include ecosystem recov-

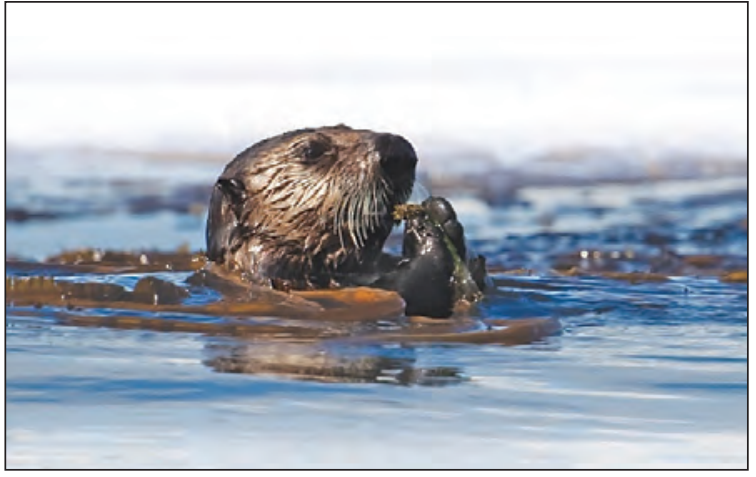

Sea otter in kelp. Photograph by Benjamin Weitzman, U.S. Geological Survey. ery from the Exxon Valdez oil spill; in particular, studies of sea otters and harlequin ducks have provided unprecedented insights into the processes and timelines of recovery of vulnerable species. We also have a long history, and ongoing efforts, to evaluate population dynamics of sea otters and their effects on other components of nearshore ecosystems. We also study sea ducks, a group of waterfowl of high conservation concern, evaluating factors on marine habitats that influence their distribution, abundance, and demography. A large component of our program is participation in Gulf Watch Alaska, which is designed to monitor marine ecosystem structure and function in the northern Gulf of Alaska.

\begin{tabular}{ccc}
\hline Time frame & Budget & \multicolumn{1}{c}{ Project partners } \\
\hline 2005 -ongoing & $>\$ 1,000,000$ & $\begin{array}{l}\text { U.S. Fish and Wildlife Service, National Oceanic and Atmospheric Administration, National Park Service, } \\
\text { Exxon Valdez Oil Spill Trustee Council }\end{array}$ \\
\hline
\end{tabular}

\section{Contact}

Daniel Esler, ASC, desler@usgs.gov, (907) 786-7068

\section{Recent Publications}

Esler, D., Ballachey, B.E., Matkin, C., Cushing, D., Kaler, R., Bodkin, J., Monson, D., Esslinger, G., and Kloecker, K., 2017, Timelines and mechanisms of wildlife population recovery following the Exxon Valdez oil spill: Deep Sea Research Part II-Topical Studies in Oceanography, v. 147, p. 36-42, https://doi.org/10.1016/j. dsr2.2017.04.007.

Esslinger, G.E., 2018, Gulf Watch Alaska Nearshore Component - Sea otter aerial survey data from Katmai National Park and Preserve, 2008-2018 (ver. 2.0, March 2020): U.S. Geological Survey data release, https://doi.org/10.5066/ F7930SG7.

Kloecker, K.A., and Monson, D.H., 2020, Gulf Watch Alaska Nearshore Component - Sea otter mortality age data from Katmai National Park and Preserve, Kenai Fjords National Park, and Prince William Sound, Alaska, 2006-2017: U.S. Geological Survey data release, https://doi.org/10.5066/ F7H993CZ.
Konar, B., Mitchell, T.J., Iken, K., Coletti, H., Dean, T., Esler, D., Lindeberg, M., Pister, B., Weitzman, B., 2019, Wasting disease and static environmental variables drive sea start assemblages in the northern Gulf of Alaska: Journal of Experimental Marine Biology and Ecology, v. 520, 10 p., https://doi.org/10.1016/j.jembe.2019.151209.

Tinker, M.T., Gill, V.A., Esslinger, G.E., Bodkin, J.L., Monk, M., Mangel, M., Monson, D.H., Raymond, W.W., and Kissling, M.L., 2019, Trends and carrying capacity of sea otters in Southeast Alaska: The Journal of Wildlife Management, v. 83, no. 5, p. 1073-1089, https://doi.org/10.1002/jwmg.21685.

Willie, M., Esler, D., Boyd, W.S., Bowman, T., Schamber, J., and Thompson, J., 2020, Annual winter site fidelity of Barrow's goldeneyes in the Pacific: The Journal of Wildlife Management, v. 84, no. 1, p. 161-171, https://doi. org/10.1002/jwmg.21767.

\section{Project Link}

https://www.usgs.gov/centers/asc/science/nearshore-marineecosystem-research 


\section{Ecology of Terrestrial Vertebrates (Caribou, Moose, Sheep, Wolves, Bears) in Alaska}

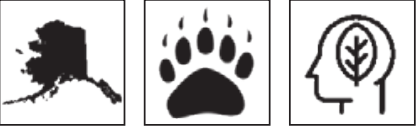

Understanding the population dynamics, predator/prey relations, and habitat ecology of large, terrestrial mammals is critical for the management of these wildlife species in Alaska and elsewhere around the world. Research conducted by the ASC on terrestrial mammals is focused on informing DOI management decisions across Alaska. Our work provides timely and highly relevant scientific information for management issues such as the response of caribou to a warming climate and human development, future possible changes in distribution and abundance, and the effects of changing habitats used for forage. Recent research objectives include the following: (1) continued monitoring of the Denali National Park caribou herd, (2) data summary and writing of a report on the population dynamics of wolves in Denali National Park, and (3) continued discussion with partners and stakeholders on future science needs and development of new research.

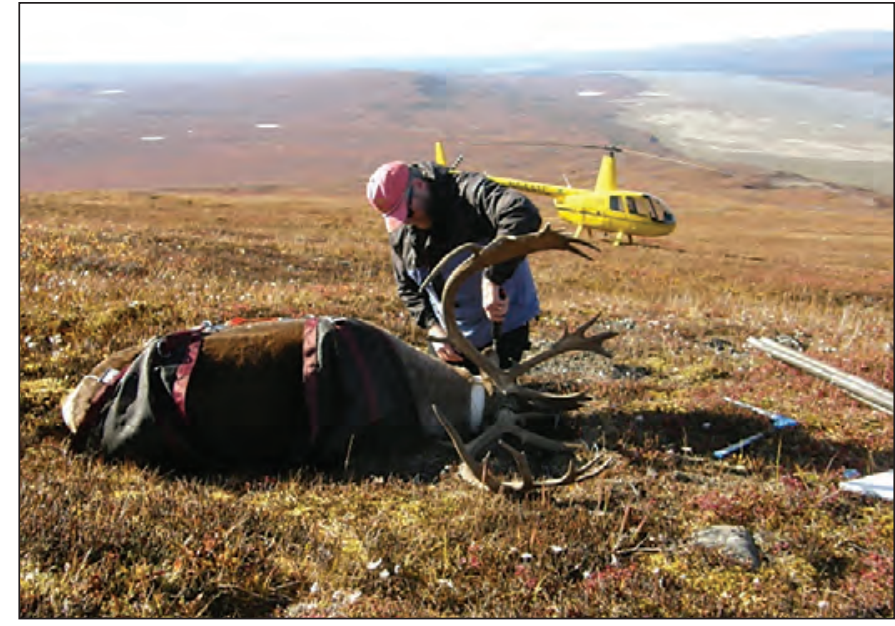

U.S. Geological Survey scientist placing radio collar on a sedated bull caribou in Alaska. Photograph by U.S. Geological Survey.

\begin{tabular}{ccc}
\hline Time frame & Budget & Project partners \\
\hline 2016 - ongoing & $\$ 100,000-\$ 499,000$ & $\begin{array}{c}\text { Alaska Department of Fish and Game, National Park Service, Yukon Department of Environment, } \\
\text { Bureau of Land Management, Industry }\end{array}$ \\
\hline
\end{tabular}

\section{Contacts}

Layne Adams, ASC, ladams@usgs.gov, (907) 786-7159

Heather Johnson, ASC, hjohnson@usgs.gov, (907) 786-7155

Project Link

https://www.usgs.gov/centers/asc/science/terrestrial-mammal-ecology-research 


\section{Birds}

\section{Seabirds and Forage Fish Ecology Program}

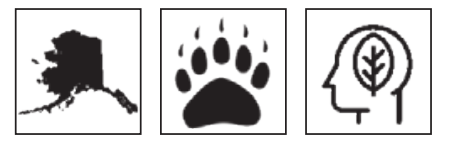

Seabirds serve as practical indicators of change in the marine environment - natural or human induced — because they can be readily monitored at colonies and at sea. USGS studies seabird population dynamics and feeding ecology for a variety of seabird species to better understand why seabird populations fluctuate over time and how natural and anthropogenic factors influence population biology. Findings from these studies are then provided to DOI management agencies and other stakeholders for their decision-making. Long-term tasks that form the core of the ASC's forage fish, seabird, and ecosystem studies include (1) compilation and analyses of data on the pelagic distribution of marine birds in the North Pacific relative to biological oceanography and changes in climate; development of methods for censusing and monitoring trends in seabird populations on land and at sea; (2) studies of oceanography, plankton, forage fish, and seabirds around major seabird colonies in Alaska; and (3) measuring the possible impact of algal toxins on the mortality on seabirds.

\begin{tabular}{cc}
\hline Time frame & \multicolumn{1}{c}{ Project partners } \\
\hline 2005-ongoing & $\begin{array}{l}\text { U.S. Fish and Wildlife Service, National Park Service, Bureau of Offshore Energy Management, Exxon Valdez Oil Spill } \\
\text { Trustee Council }\end{array}$ \\
\hline
\end{tabular}

\section{Contacts}

John Piatt, ASC, jpiatt@usgs.gov, (360) 774-0516

Mayumi Arimitsu, ASC, marimitsu@usgs.gov, (907) 364-1593

\section{Recent Publications}

Arimitsu, M.L., and Piatt, J.F., 2019. Monitoring long-term changes in forage fish distribution, abundance and body condition: Gulf Watch Alaska Long Term Monitoring Program, 2 p., https://pubs.er.usgs.gov/publication/70203368.

Drew, G.S., and Piatt, J.F., 2015, North Pacific Pelagic Seabird Database (NPPSD): U.S. Geological Surv

ey data release (ver. 3.0, February 2020), https://doi. org/10.5066/F7WQ01T3.

McGowan, D. W., Goldstein, E.D., Arimitsu, M.L., Deary, A.L., Ormseth O., De Robertis, A., Horne, J.K., Rogers, L.A., Wilson, M.T., Coyle, K.O., Holderied, K., Piatt, J.F., Stockhausen, W., and Zador, S.G., 2020, Spatial and temporal dynamics of Pacific capelin

(Mallotus catervarius) in the Gulf of Alaska-Implications for ecosystem-based fishery management: Marine Ecology Progress Series, v. 637, p. 117-140, https://doi.org/10.3354/ meps13211.

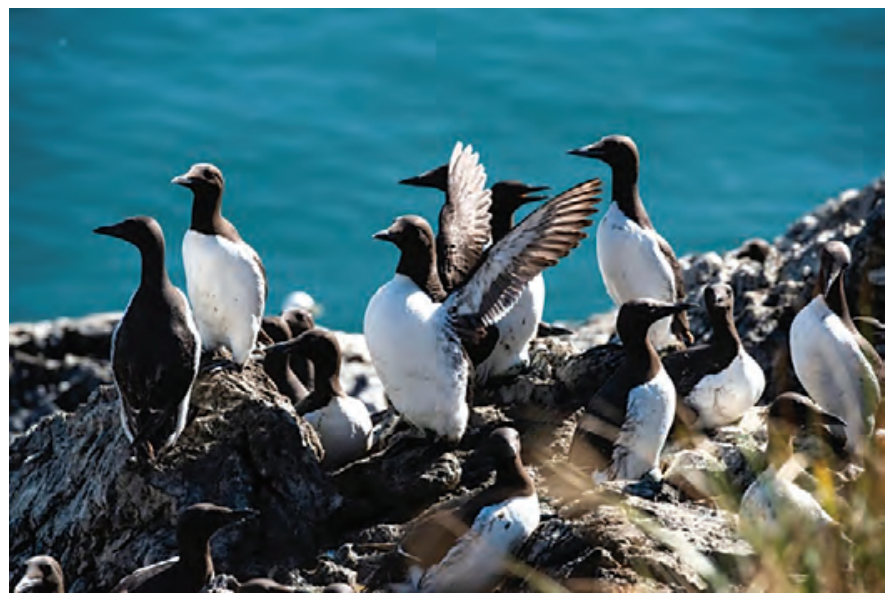

Common murres in a colony in Cook Inlet, south-central Alaska, 2017. Photograph by Sarah Schoen, U.S. Geological Survey. 


\section{Role of Gulls in Alaska in the Dissemination of Antimicrobial-Resistant E. coli}

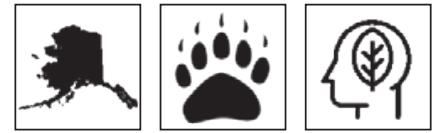

Two ASC staff members have been conducting research into the role of gulls in Alaska in the dissemination of antimicrobial-resistant E. coli bacteria — research that was initiated after the State of Alaska found high bacterial levels in the Kenai River starting in 2014 . Current research objectives of the ASC include (1) determining migratory routes of large gull species that are breeding in Alaska and are potential reservoir and dispersal agents of antibiotic resistant bacteria, and (2) quantifying levels of risk - by geographic area - for the spread of bacteria by national and international migratory routes.

\section{Contact}

Andy Ramey, ASC, aramey@usgs.gov (907) 786-7174

\section{Recent Publications}

Ahlstrom, C.A., Bonnedahl, J., Woksepp, H., Hernandez, J., Reed, J.A., Tibbitts, L., Olsen, B. Douglas, D.C., and Ramey, A.M.,, 2019, Satellite tracking of gulls and genomic characterization of faecal bacteria reveals environmentally mediated acquisition and dispersal of antimicrobial-resistant Escherichia coli on the Kenai Peninsula, Alaska: Molecular Ecology, v. 28, no. 10, p. 2531-2545, https://doi.org/10.1111/mec.15101.

Ahlstrom, C.A., Ramey, A.M., Woksepp, H. and Bonnedahl, J., 2019a, Early emergence of mcr- 1-positive Enterobacteriaceae in gulls from Spain and Portugal: Environmental Microbiology Reports, v. 11, no. 5, p. 669-671, https://doi.org/10.1111/1758-2229.12779.

Ahlstrom, C.A., Ramey, A.M., Woksepp, H., and Bonnedahl, J., 2019b, Repeated detection of carbapenemase-producing Escherichia coli in gulls inhabiting Alaska: Antimicrobial Agents and Chemotherapy, v. 63, no. 8, 4 p., https://aac.asm. org/content/63/8/e00758-19.

Franklin, A.B., Ramey, A.M., Bentler, K.T., Barrett, N.L., McCurdy, L.M., Ahlstrom, C.A., Bonnedahl, J., Shriner, S.A., and Chandler, J.C., 2020, Gulls as sources of environmental contamination by colistin-resistant bacteria: Scientific Reports, v. 10, 10 p. , https://doi.org/10.1038/ s41598-020-61318-2.

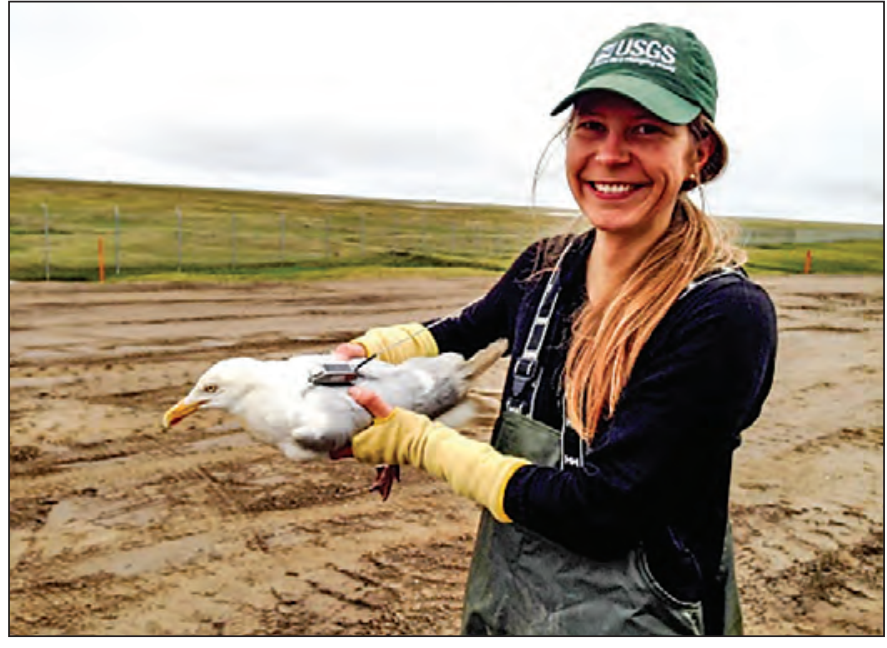

U.S. Geological Survey scientist holding gull with satellite transmitter.

\begin{tabular}{cc}
\hline Time frame & \multicolumn{1}{c}{ Project partners } \\
\hline $2165-20$ & $\begin{array}{c}\text { U.S. Department of Agriculture, U.S. Fish and } \\
\text { Wildlife Service, Alaska Department of Health } \\
\text { and Social Services }\end{array}$ \\
\hline
\end{tabular}

Ramey, A.M., and Ahlstrom, C.A., 2020, Antibiotic resistant bacteria in wildlife - Perspectives on trends, acquisition and dissemination, data gaps, and future directions: Journal of Wildlife Diseases, v. 56, no. 1, p. 1-15, https://doi.org/10.7589/2019-04-09.

Ramey, A.M., Ahlstrom, C.A., van Toor, M.L., Woksepp, H., Chandler, J.C., Reed, J.A., Reeves, A.B., Waldenström, J., Franklin, A.B., Bonnedahl, J., and Douglas, D.C., 2020, Tracking data for three large-bodied gull species and hybrids (Larus spp.) (ver 1.0, June 2020): U.S. Geological Survey data release, https://doi.org/10.5066/P9FZ4OJW.

\section{Project Link}

https://www.usgs.gov/centers/asc/science/antibiotic-resistantbacteria-migratory-birds 


\section{Population Ecology of Waterfowl and Loons}

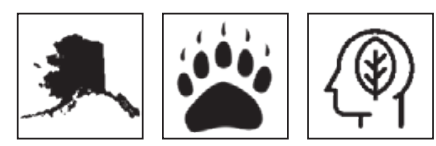

The Population Ecology of Waterfowl and Loons project at the ASC includes a variety of research directions and methods that inform our partners. In 2020, research objectives included (1) quantifying and mapping abundance and distribution of waterbird species in western and northern Alaska; (2) mapping data important for determining population strucutre among North American sea duck species; (3) conducting demographic analyses and trends for species of management concerns, such as, spectacled eiders; (4) surveying and assessing avian influenza in loon species; and (5) studying aspects of general ecology of waterfowl and loons that may inform management agency decisions.

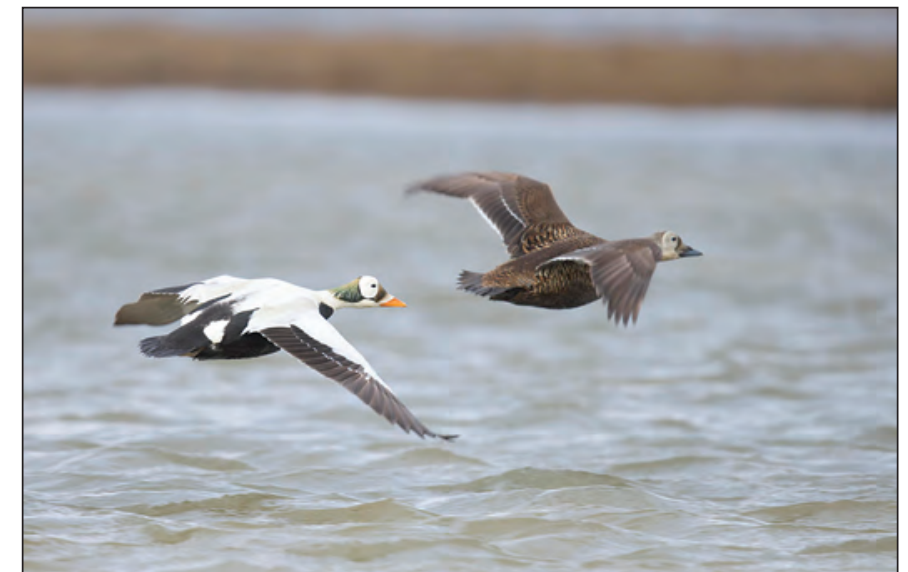

Pair of spectacled eiders flying near the Colville River, northern Alaska, 2013. Photograph by Ryan Askren, U.S. Geological Survey.

\begin{tabular}{ccc}
\hline Time frame & Budget & Project partners \\
\hline $2005-$ ongoing & $\$ 100,000-\$ 499,000$ & Bureau of Land Management, U.S. Fish and Wildlife Service, Bureau of Ocean Energy Management \\
\hline
\end{tabular}

\section{Contacts}

Paul Flint, ASC, pflint@usgs.gov, (907) 786-7183

Joel Schmutz, ASC, jschmutz@usgs.gov, (907) 786-7186

John Pearce, ASC, jpearce@usgs.gov, (907) 786-7094

\section{Recent Publications}

Amundson, C.L., Flint, P.L., Stehn, R.A., Wilson, H.M., Larned, W.W., and Fischer, J.B., 2019, Spatio-temporal population change of Arctic-breeding waterbirds on the Arctic Coastal Plain of Alaska: Avian Conservation and Ecology, v. 14, no. 1, 198 p., https://doi.org/10.5751/ACE01383-140118.

Flint, P.L., Patil, V.P., Shults, B.S., and Thompson, S.J., 2020, Prioritizing habitats based on abundance and distribution of molting waterfowl, in the Teshekpuk Lake Special Area of the National Petroleum Reserve, Alaska:

U.S. Geological Survey Open-File Report 2020-1034, 16 p., https://doi.org/10.3133/ofr20201034.

Lewis, T.L., Swaim, M., Schmutz, J.A., and Fischer, J.B., 2019, Improving population estimates of threatened spectacled eiders - Correcting aerial counts for visibility bias: Endangered Species Research. v. 39, p. 191-206, https://doi.org/10.3354/esr00959.

Pearce, J.M., and others, 2019, Visualizing populations of North American Sea Ducks-Maps to guide research and management planning: U.S. Geological Survey Open-File Report 2019-1142, 50 p., plus appendixes, https://doi. org/10.3133/ofr20191142.
Poessel, S.A., Uher-Koch, B.D., Pearce, J.M., Schmutz, J.A., Harrison, A.L., Douglas, D.C., von Biela, V.R., and Katzner, T.E., 2020, Movements and habitat use of loons for assessment of conservation buffer zones in the Arctic Coastal Plain of northern Alaska: Global Ecology and Conservation, v. 22, 15 p., https://doi.org/10.1016/j.gecco.2020.e00980.

Uher-Koch, B.D., Spivey, T.J. Van Hemert, C.R. Schmutz, J.A. Jiang, K. Wan, X.-F. and Ramey, A.M., 2019, Serologic evidence for influenza a virus exposure in three loon species breeding in Alaska, USA: Journal of Wildlife Diseases, v. 55 , no. 4, p. 862-867, https://doi.org/10.7589/201806-165.

Uher-Koch, B.D., Wright, K.G., and Schmutz, J.A., 2019, The influence of chick production on territory retention in Arctic breeding Pacific and Yellow-billed loons: The CondorOrnithological Applications, v. 121, no. 1, p. 1-11, https://doi.org/10.1093/condor/duy021.

\section{Project Links}

https://www.usgs.gov/centers/asc/science/waterfowl-research? qt-science_center_objects-0\#qt-science_center_objects https://www.usgs.gov/centers/asc/science/loon-research?qtscience_center_objects $=0 \#$ qt-science_center_objects 


\section{Population Ecology and Habitats of Alaska Landbirds}

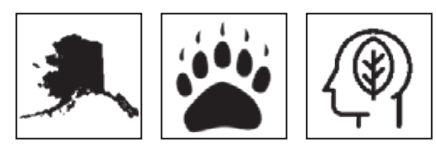

Alaska supports more than 130 species of breeding landbirds, including many that migrate to neotropical wintering areas. Population declines have been documented for several species over the past few decades and land managers in Alaska are requesting information on possible drivers of population change, such as spruce beetle epidemics, fire, and disease. Little information exists on the status of Alaskan landbird populations in relation to those of temperate regions. Objectives of this project are to (1) coordinate a cooperative, regional program to monitor population trends of landbirds breeding in northern ecoregions; investigate relations between the distribution of breeding landbirds and terrestrial habitats at the landscape level; and (3) examine population dynamics governing population trends. Methods used include annual ground surveys and banding to understand changes in population size and demography over time.

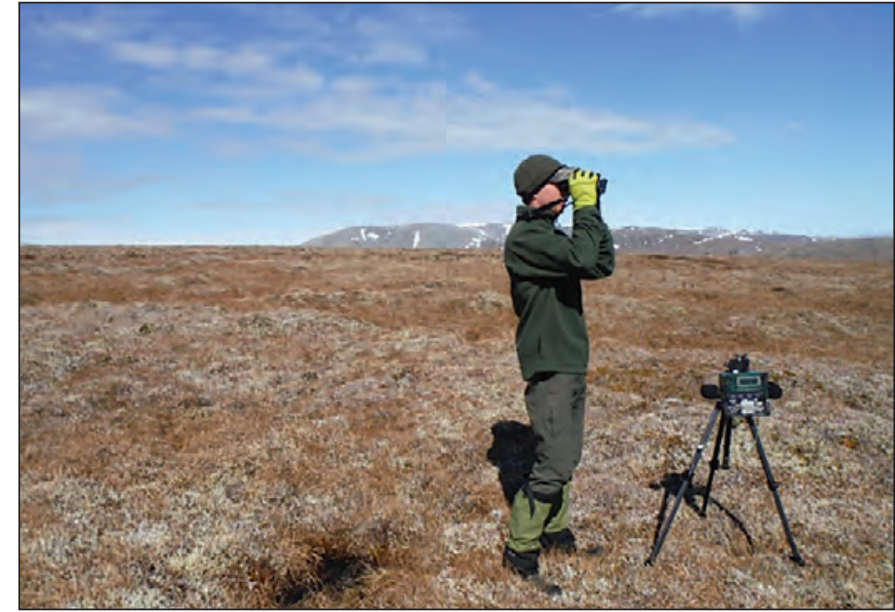

U.S. Geological Survey biologist conducting a bird survey on Alaska's Seward Peninsula. Photograph by Lance McNew, U.S. Geological Survey.

\begin{tabular}{ccrc}
\hline Time frame & Budget & Project partners \\
\hline 2001-ongoing & $\begin{array}{c}\$ 100,000- \\
\$ 500,000\end{array}$ & $\begin{array}{r}\text { Canadian Wildlife Service, U.S. Fish and Wildlife Service-Alaska Region, U.S. Fish and Wildlife Service- } \\
\text { Alaska Migratory Bird Management, National Park Service - Alaska Region, Bureau of Land Management- } \\
\text { Alaska State Office and Arctic Office, University of Alaska Fairbanks, Alaska Department of Fish and Game }\end{array}$ \\
\hline
\end{tabular}

\section{Contacts}

Colleen Handel, ASC, cmhandel@usgs.gov, (907) 786-7181

Steve Matsuoka, ASC, smatsuoka@usgs.gov, (907) 786-7075

\section{Recent Publications}

Robinson, B.W., Withrow, J.J., Richardson, R.M., Gill, Jr., R.E., Johnson, A.S., Lovette, I.J., Johnson, J.A., DeGange, A.R., and Romano, M.D., 2020, Further information on the avifauna of St. Matthew and Hall islands, Bering Sea, Alaska: Western Birds, v. 51, no. 2, p. 78-91, https://doi.org/10.21199/WB51.2.1.

Roy, C., Michel, N.L., Handel, C.M., Van Wilgenburg, S.L., Burkhalter, J.C., Gurney, K.E.B., Messmer, N.L., Princé, K., Rushing, C.S., Saracco, J.F., Schuster, R., Smith, A.C., Smith, P.A., Sólymos, P., Venier, L.A., and Zuckerberg, B., 2019, Monitoring boreal avian populations-How can we estimate trends and trajectories from noisy data?: Avian Conservation and Ecology, v. 14, no. 2,26 p., https://doi.org/10.5751/ACE-01397-140208.
Slager, D., Epperly, K., Ha, R., Rohwer, S., Woodall, C.W., Van Hemert, C.R., and Klicka, J., 2020, Cryptic and extensive hybridization between ancient lineages of American crows: Molecular Ecology, v. 29, no. 5, p. 956-969, http://doi.org/10.1111/mec.15377.

Sólymos, P., Toms, J.D., Matsuoka, S.M., Cumming, S.G., Barker, N.K.S., Thogmartin, W.E., Stralberg, D., Crosby, A.D., Dénes, F.V., Haché, S., Mahon, C.L., Schmiegelow, F.K.A., and Bayne, E.M., 2020, Lessons learned from comparing spatially explicit models and the Partners in Flight approach to estimate population sizes of boreal birds in Alberta, Canada: The Condor-Ornithological Applications v. 122, p. 1-22, https://doi.org/10.1093/ condor/duaa007.

Stralberg, D., and others, 2020, Climate-change refugia in boreal North America - What, where, and for how long?: Frontiers in Ecology and the Environment, v. 18, no. 5., p. 261-270, https:/doi.org/10.1002/fee.2188.

\section{Project Link}

https://www.usgs.gov/centers/asc/science/borealpartners-flight 


\section{Population Status and Ecology of North Pacific Shorebirds}

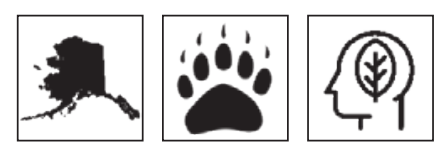

Alaska is widely recognized as a global center for breeding shorebirds, as 90 percent of the migratory species in the Western Hemisphere have breeding populations in Alaska. Research objectives of this project are to (1) provide information needed for management agencies, such as current distribution and abundance of shorebird species in Alaska; (2) factors involved in driving population changes in Alaska and throughout the broad non-breeding distribution of these species; and (3) evaluation of new and emerging topics with this species group. Methods involve population genetics, satellite telemetry and other tagging, and ground surveys.

\begin{tabular}{ccc}
\hline Time frame & Budget & \multicolumn{1}{c}{ Project partners } \\
\hline $2001-$ & $\begin{array}{c}\$ 100,000- \\
\text { present }\end{array}$ & $\begin{array}{c}\text { U.S. Fish and Wildlife Service, } \\
\text { Bureau of Land Management, Alaska } \\
\text { Department of Fish and Game, } \\
\text { international partners }\end{array}$ \\
\hline
\end{tabular}

\section{Contacts}

Dan Ruthrauff, ASC, druthrauff@usgs.gov, (907) 786-7162

Lee Tibbitts, ASC, 1tibbitts@usgs.gov, (907) 786-7038

\section{Recent Publications}

Almeida, J.B., Lopes, I.F., Oring, L.W., Tibbitts, T.L., Pajot, L.M., and Lanctot, R.B., 2020, After-hatch and hatch year buff-breasted sandpipers Calidris subruficollis can be sexed accurately using morphometric measures: Wader Study, v. 127 , no. 2, p. 37-42, https://doi.org/10.18194/ws.00189.

Almeida, J.B., Lopes, I.F., Oring, L.W., Tibbitts, T.L., Pajot, L.M., and Lanctot, R.B., 2020, After-hatch and hatch year Buff-breasted Sandpipers (Calidris subruficollis) can be sexed accurately using morphometric measures: Wader Study, v. 127, no. 2,p. 37-42, https://doi.org/10.18194/ ws.00189.

Chan, Y-C., Tibbitts, T.L., Lok, T., Hassell, C.J., Peng, H.B., Ma, Z., Zhang, Z., and Piersma, T., 2019, Filling knowledge gaps in a threatened shorebird flyway through satellite tracking: Journal of Applied Ecology, v. 56, no. 10, p. 2305-2315,https:/doi.org/10.1111/1365-2664.13474.

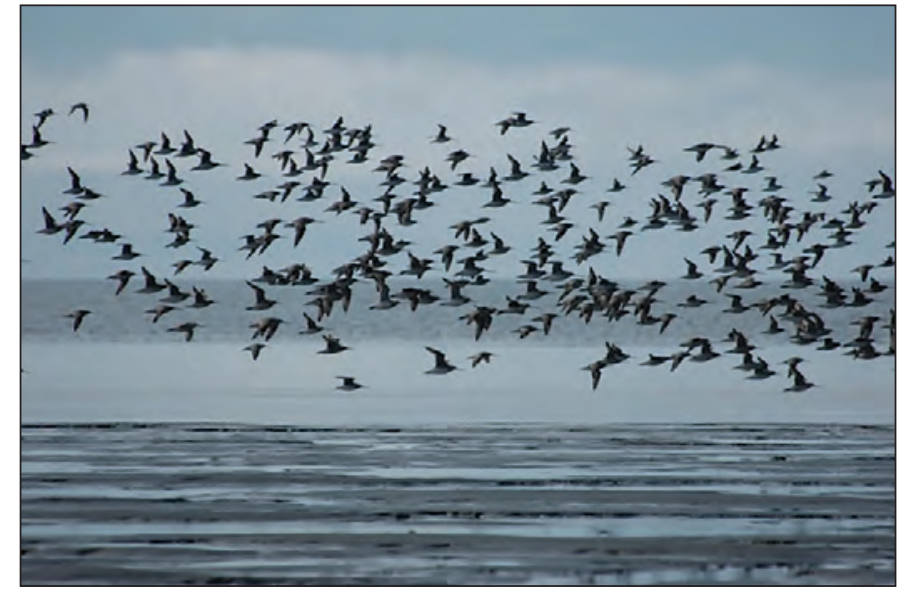

Bar-tailed godwit flock flying over the mudflats on Cape Avinof, western Alaska. Photograph by Dan Ruthrauff, U.S. Geological Survey.

Kok, E., Tibbitts, T.L., Douglas, D.C., Howey, P., Dekinga, A.A., Gnep, B., and Piersma, T., 2020, A red knot as a black swan-How a single bird shows navigational abilities during repeat crossings of the Greenland Icecap: Journal of Avian Biology, v. 51, no. 8, 11 p., https://doi.org/10.1111/ jav.02464.

Naves, L.C., Keating, J.M., Tibbitts, T.L., and Ruthrauff, D.R., 2019, Shorebird subsistence harvest and indigenous knowledge in Alaska-Informing harvest management and engaging users in shorebird conservation: The CondorOrnithological Applications, v. 121, no. 2, p. 1-19, https://doi.org/10.1093/condor/duz023.

Ruthrauff, D.R., 2019. Alaska shorebird conservation plan (ver. III): Anchorage, Alaska, Alaska Shorebird Group, 138 p., https://pubs.er.usgs.gov/publication/70203041.

Ruthrauff, D.R., Handel, C.M., Tibbitts. T.L., and Gill, Jr, R.E., 2020, Through thick and thin-Sexing bristlethighed curlews Numenius tahitiensis using measures of bill depth: Wader Study, v. 127, no. 1, p. 31-36, https://doi. org/10.18194/ws.00171.

Ruthrauff, D R., Tibbitts, T.L., and Gill, Jr, R.E., 2019: Flexible timing of annual movements across consistently used sites by marbled godwits breeding in Alaska: The AukOrnithological Advances, v. 136, no. 1, p. 1-11, http://doi. org/10.1093/auk/uky007. 
Ruthrauff, D.R., Tibbitts, T.L., and Patil, V.P., 2019, Survival of bristle-thighed curlews equipped with externally mounted transmitters: Wader Study, v. 126, no. 2, 7 p., https://doi. org/10.18194/ws.00145.

Tibbitts, T.L., Ruthrauff, D.R., Underwood, J.G., and Patil, V.P., 2019, Factors promoting the recolonization of Oahu, Hawaii, by bristle-thighed curlews: Global Ecology and Conservation, v. 21, 10 p., https://doi.org/10.1016/j. gecco.2019.e00785.
Weiser, E.L., and others, 2020, Annual adult survival drives trends in Arctic-breeding shorebirds but knowledge gaps in other vital rates remain: The Condor-Ornithological Applications, v. 133, no. 3, 14 p, https://doi.org/10.1093/ condor/duaa026.

\section{Project Link}

https://www.usgs.gov/centers/asc/science/shorebird-research

\section{Contaminant Exposure, Bioaccumulation, and Ecological Effects in Aquatic and Terrestrial Habitats}
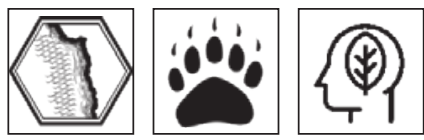

Alaska contains a diverse suite of aquatic habitats that provide critical ecosystem services. Environmental contaminants are among the key threats to the viability of these habitats and the species they support. Although the proximity of these water bodies to contaminant sources is important, the intrinsic ecological properties of each habitat type can affect contaminant cycling and effects. The USGS Forest and Rangeland Ecosystem Science Contaminant Ecology Program works across a range of aquatic habitats in the Western United States and Alaska to (1) evaluate contaminant exposure, (2) assess the accumulation through the food web, and (3) quantify the biological effects in aquatic and aquatic-dependent wildlife. Furthermore, the habitat, landscape, and land-use patterns that contribute to contaminant dynamics will be measured. For example, mercury, a toxic metal, may threaten seabird species such as the Kittlitz's murrelet. The USGS measured mercury concentrations in Kittlitz's murrelet eggshells, guano, blood, and feathers from four locations in Alaska. Results of this study indicate that mercury concentrations from two

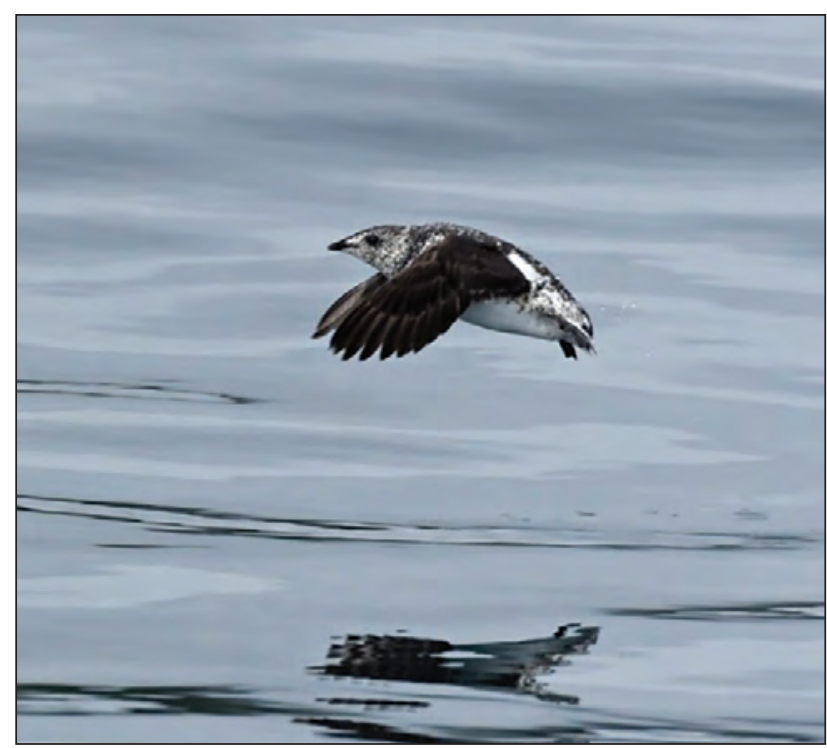

Kittlittz's murrelet flying above the water in Cook Inlet, southcentral Alaska. Photograph by Sarah Schoen, U.S. Geological Survey.

Kittlitz's murrelets at Glacier Bay National Park and one at Adak Island were greater than those associated with impaired reproduction in other bird species, and may merit further study to determine the potential threat of mercury at the population scale.

\begin{tabular}{cc}
\hline Time frame & Project partners \\
\hline $2010-20$ & U.S. Fish and Wildlife Service, National Park Service, Biodiversity Research Institute \\
\hline
\end{tabular}

\section{Contact}

Collin Eagles-Smith, Forest and Rangeland Ecosystem Science Center, ceagles-smith@usgs.gov (541) 750-0949

\section{Recent Publication}

Kenney, L.A., Kaler, R.S., Kissling, M.L., Bond, A.L., and Eagles-Smith, C.A., 2018, Mercury concentrations in multiple tissues of Kittlitz's murrelets (Brachyramphus brevirostris): Marine Pollution Bulletin, v. 129, no. 2, p. 675-680, https://doi.org/10.1016/j.marpolbul.2017.10.055. 


\section{Epidemic of Beak Deformities (Avian Keratin Disorder) Among Wild Bird Populations}
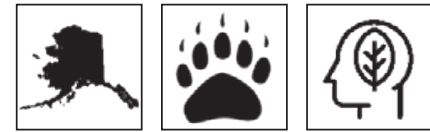

Thousands of land birds from 30 different species in Alaska have been reported with grossly deformed beaks since January 1998. Most sightings have been concentrated in south-central Alaska, primarily in black-capped chickadees. Outside Alaska, there have been about 300 reports of individuals of more than 80 species of wild birds with similarly deformed beaks scattered across North America. The geographic distribution of deformities and high prevalence among resident birds suggest an acute, ecosystem-wide problem, but the cause and geographic origin of deformities are still unknown. The research objectives for this project are to determine (1) the factors causing the disease, (2) its geographic distribution, and (3) possible mitigation activities to limit continuation of the deformities in birds. Methods thus far to understand the disease have involved contaminant screening, genetic defect evaluation, changes in forage quality, bone and keratin evaluation, and viral and bacterial factors.

\section{Contacts}

Colleen Handel, ASC, cmhandel@usgs.gov, (907) 786-7181

Caroline Van Hemert, ASC, cvanhemert@usgs.gov, (907)

786-7167

\section{Recent Publications}

Hofmeister, E., and Van Hemert, C.R., 2018, The effects of climate change on disease spread in wildlife, in Miller, E.R., Lamberski, N., and Calle, P., eds., Fowler's zoo and wild animal medicine current therapy: Elsevier Health Sciences, v. 9, p. 247-254, https://pubs.er.usgs.gov/publication/70198103.

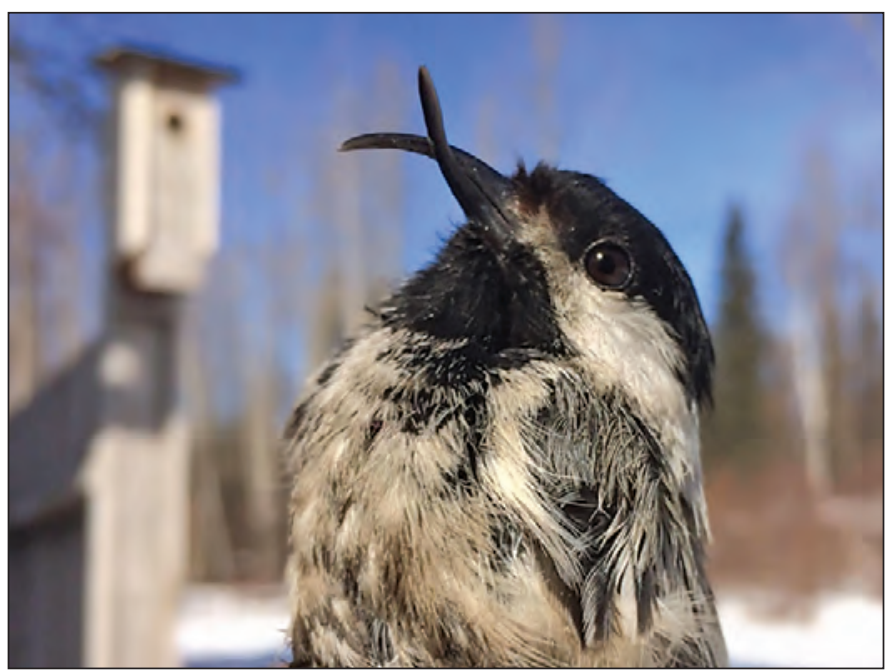

Black-capped chickadee with a beak that has grown long and crossed. Photograph by Rachel Richardson, U.S. Geological Survey.

\begin{tabular}{ccc}
\hline Time frame & Budget & \multicolumn{1}{c}{ Project partners } \\
\hline $2005-$ & $<\$ 100,000$ & U.S. Fish and Wildlife Service- \\
ongoing & & Alaska Regional Office, Alaska \\
& & Migratory Bird Management Office, \\
& Bureau of Land Management- \\
& & Alaska State Office, citizen science \\
& observers and university partners \\
\hline
\end{tabular}

Zylberberg, M., Van Hemert, C.R., Handel, C.M., and DeRisi, J.L., 2018, Avian keratin disorder of Alaska black-capped chickadees is associated with Poecivirus infection: Virology Journal, v. 15, no. 100, 9 p., https://doi.org/10.1186/s12985018-1008-5.

\section{Project Link}

https:/www.usgs.gov/centers/asc/science/beak-deformitieslandbirds 


\section{Fish}

\section{Fish Ecology and Conservation}

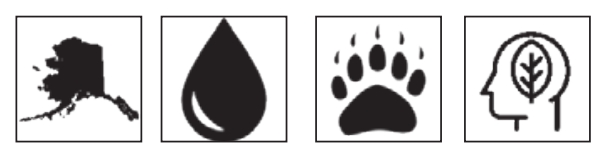

Federal partners such as the FWSS, U.S. Forest Service, and BLM often look to the USGS for assistance with statistical study design, analysis of data, monitoring design, and interpretation of research results related to aquatic systems and biota. The USGS Aquatic Landscape Ecology Research Team provides technical assistance to partners with questions related to aquatic conservation and fish ecology. Activities involve developing and applying models as well as statistical assistance. For example, researchers from USGS, Oregon State University, and the U.S. Forest Service studied coho salmon, from hatching through the first summer of life, in the Copper River Delta, Alaska, to evaluate links between coho salmon phenology and stream thermal variability. The results of this study provide insights into the interactions between environmental variability and the early life-history stages of coho salmon.

\section{Contact}

Jason Dunham, Forest and Rangeland Ecosystem Science Center, jdunham@usgs.gov, (541) 750-0990

\section{Recent Publication}

Campbell, E.Y., Dunham, J.B., Reeves, G.H., and Wondzell, S.M., 2018, Phenology of hatching, emergence, and end-of-season body size in young-of-year coho salmon in thermally contrasting streams draining the Copper River Delta, Alaska: Canadian Journal of Fisheries and Aquatic Sciences, v. 76, p. 185-191, https://doi.org/10.1139/cjfas-2018-0003.

\section{Project Link}

https://www.usgs.gov/center-news/phenology-young-coho-salmon-copper-river-delta-alaska 


\section{Heat Stress in Alaska's Pacific Salmon}
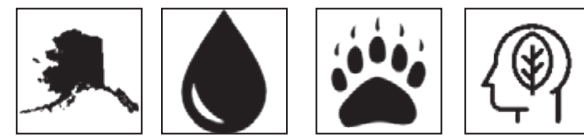

Pacific salmon are cold-water fishes that historically have been limited by cold temperatures in Alaska. Rapid warming at northern latitudes has increased freshwater temperatures and raised the possibility that summer water temperatures in some of Alaska's freshwaters are now stressful for migrating adult Pacific salmon. The objective of this study was to understand whether contemporary water temperatures induce stress in Yukon River Chinook salmon, a population that failed to recover from decline. The methods integrate an experiment and field collections of muscle tissue samples for laboratory analysis of heat stress biomarkers (gene transcription and heat shock proteins) through collaborations with researchers from the USGS Western Ecological Research Center and Leetown Science Center. In the experiment, two contemporary summer water temperatures (18 and 21 degrees Celsius) induced heat stress. In field collections across the watershed, about one-half of the field-caught Chinook salmon had biomarkers consistent with heat stress. Given that heat stress increases the risk of in-river mortality prior to spawning and that salmon are managed by in-river counts of spawning adults, our findings suggest the potential for in-river abundance counts (that is, escapement) to overestimate the true number of spawning fish and result in overharvest.

\begin{tabular}{ccc}
\hline Time frame & Budget & Project partners \\
\hline $2016-20$ & $\$ 500,000-\$ 1,000,000$ & $\begin{array}{c}\text { Arctic-Yukon-Kuskokwim Sustainable Salmon Initiative, U.S. Fish and Wildlife Service, Alaska } \\
\text { Department of Fish and Game }\end{array}$ \\
\hline
\end{tabular}

\section{Contact}

Vanessa Von Biela, ASC, vvonbiela@usgs.gov, (907) 227-4683.

\section{Recent Publication}

Bowen, L, von Biela, V.R., McCormick, S.D, Regish, A.M., Waters, S., Durbin-Johnson, B., Britton, M., Settles, M., Donnelly, D.S., Laske, S., Carey, M.P., Brown. R.J., and Zimmerman, C.E., 2020, Transcriptomic response to elevated water temperatures in adult migrating Yukon River Chinook salmon (Oncorhynchus tshawytscha): Conservation Physiology, v. 8, no. 1, 22 p., https://doi.org/10.1093/conphys/coaa084.

Donnelly, D.S., von Biela, V.R., McCormick, S.D., Laske, S., Carey, M.P., Waters, S., Bowen, L., Brown, R.J., Larson, S., and Zimmerman, C.E., 2020, A manipulative experimental thermal challenge protocol for adult salmonids in remote field settings: Conservation Physiology, v. 8, no. 1, 11. p., https://doi.org/10.1093/conphys/coaa074.

von Biela, V.R., Bowen, L., McCormick, S.D., Carey, M.P., Donnelly, D.S., Waters, S., Regish, A., Laske, S.M., Brown, R.J., Larson, S., Zuray, S., Zimmerman, C.E., 2020, Evidence of prevalent heat stress in Yukon River Chinook salmon: Canadian Journal of Fisheries and Aquatic Sciences, v. 77, no. 12, p. 1878-1892, https://doi.org/10.1139/cjfas-2020-0209.

\section{Project Link}

https://www.usgs.gov/centers/asc/science/assessing-heat-stress-migrating-yukon-river-chinook-salmon 


\section{Nearshore Fish Surveys in the Beaufort Sea}
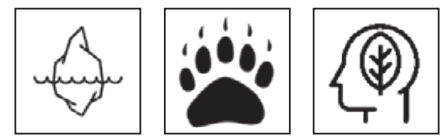

In the Arctic, rapid changes in temperature and salinity have led to changes in locations where fish commonly occur. Recent offshore survey efforts provide an opportunity to detect these changes and to compare fish abundance between offshore and nearshore habitats to understand whether nearshore habitats are used for specific life stages (such as juvenile rearing, feeding, or reproduction). Updated information on fish community and use of nearshore habitats will provide management agencies with information for assessments and will improve understanding of current susceptibility and risks of development and production in Federal waters. For example, information from this study will support BOEM in assessing whether red-throated loons are behaviorally affected by industrial activities and in assessing if nearshore fish communities are sufficiently abundant and of adequate nutrition to enable loons to be reproductively successful.

\section{Contact}

Vanessa Von Biela, ASC, vvonbiela@usgs.gov, (907) 786-7073

\section{Project Link}

https://www.usgs.gov/energy-and-minerals/energy-resourcesprogram/science/alaska-petroleum-systems

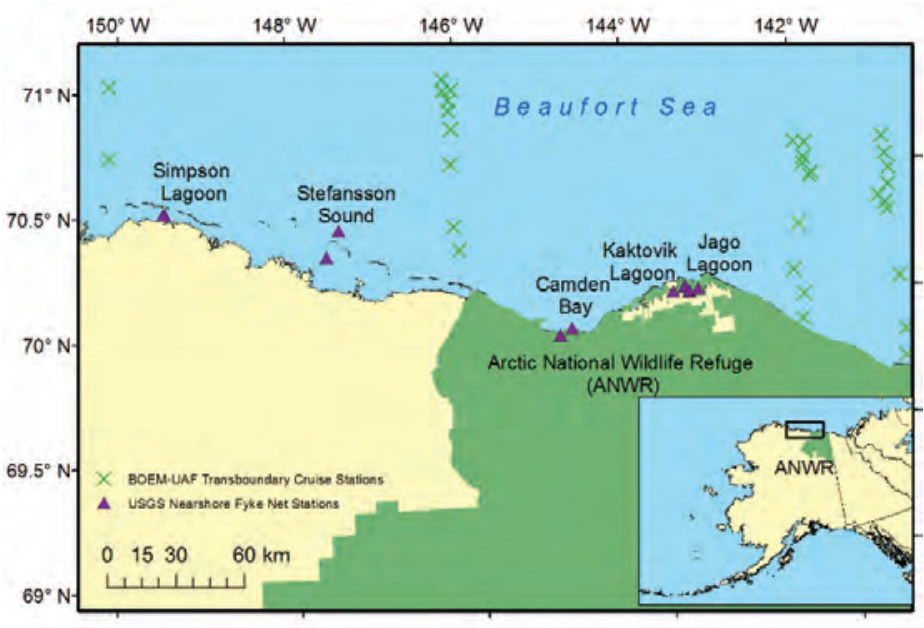

Fish sample survey locations on Beaufort Sea coast, northern Alaska. Image provided by Vanessa von Biela, U.S. Geological Survey.

\begin{tabular}{ccc}
\hline Time frame & Budget & Project partners \\
\hline $2017-20$ & $\$ 500,000-\$ 1,000,000$ & $\begin{array}{c}\text { Bureau of Ocean Energy } \\
\text { Management }\end{array}$ \\
\hline
\end{tabular}




\section{Habitat}

\section{Beavers Impacting Tundra Ecosystems-Quantifying Effects on Hydrology, Permafrost, Water Quality, and Fish Habitat in Noatak Wild and Scenic River Basin, Alaska}

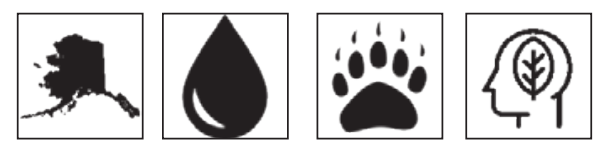

The North American beaver (Castor canadensis) has expanded beyond its historic range into tundra ecosystems, potentially impacting water quality, hydrology, and food webs of Arctic streams. Beaver dams create impoundments, flooding permafrost soils in tundra catchments and causing abrupt thaw. Our objective is to predict the consequences of beaver range expansion on the hydrology, water quality, and food webs of tundra ecosystems. Our methods are to (1) quantify the local and downstream effects of beaver ponds on water quality and hydrologic conditions, and (2) assess how beaverinduced changes affect fish growth and bioaccumulation of mercury. These data will provide a comprehensive examination of the physical, chemical, and biological consequences of beaver dams at the riverscape level and provide knowledge relevant to forecasting future changes in the Arctic. We will publish scientific findings in peer-reviewed journals and an NPS resource brief to highlight the impacts of beavers on Arctic ecosystems to promote public education.

\begin{tabular}{ccc}
\hline Time frame & Budget & Project partners \\
\hline $2019-21$ & $\begin{array}{c}\$ 100,000- \\
\$ 500,000\end{array}$ & $\begin{array}{c}\text { National Park Service, University } \\
\text { of Alaska Fairbanks }\end{array}$ \\
\hline
\end{tabular}

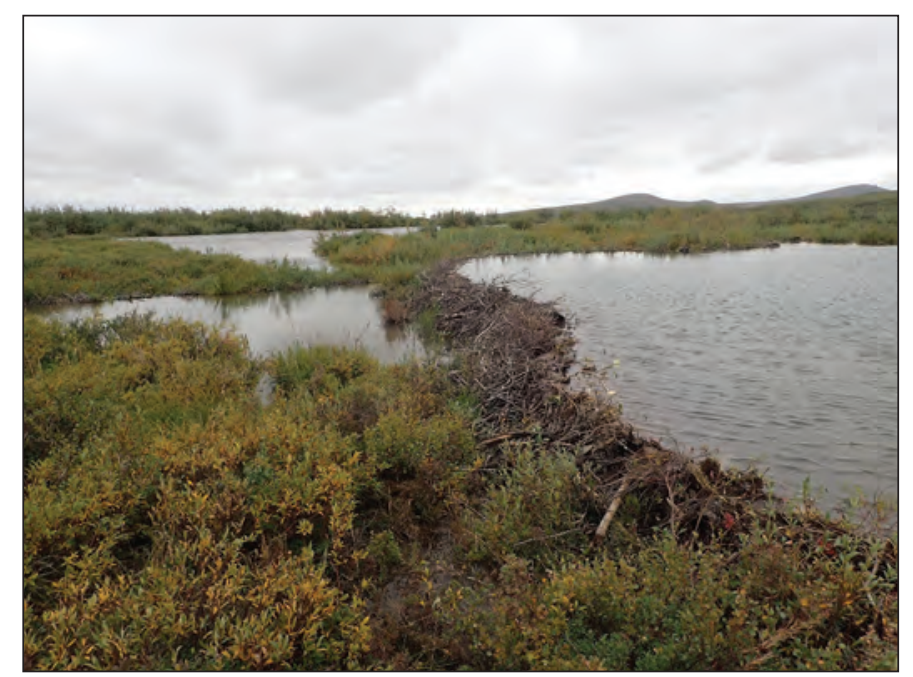

Beaver dam on Rabbit Creek, Cape Krusenstern National Monument, northwestern Alaska. Photograph by Mike Carey, U.S. Geological Survey.

\section{Contact}

Michael P. Carey, ASC, mcarey@usgs.gov, (907) 786-7197

Project Link

https:/www.usgs.gov/centers/asc/science/beavers-impactingtundra-ecosystems-bite?qt-science_center_objects=0\#qt-science_center_objects 


\section{Land Cover Classification and Change Detection on the Kenai Peninsula, 1973-2017}
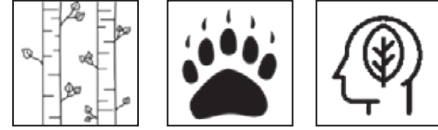

Across the Kenai Peninsula lowlands of south-central Alaska and over the last one-half century, disturbance events have removed large areas of forest while succession and landscape evolution have simultaneously facilitated forest regrowth and expansion. Assessing patterns of postdisturbance succession requires long-term monitoring. The objectives of this study were to provide land managers with a dataset capable of quantifying where and when prominent land-cover change has occurred since 1973. Project methods involve classifying land cover and quantifying land-cover change over time using Landsat legacy imagery for three historical periods on the western Kenai Peninsula: 19732002, 2002-2017, and 1973-2017. Scenes from numerous Landsat sensors were acquired from 1973 to 2017 and were used to classify and track vegetation cover using a random forest classifier. Land-cover types are summarized by era and spatially combined to produce a dataset capturing spatially explicit land-cover change at a moderate 30 -meter resolution. Products include a spatially explicit dataset that quantifies land-cover types and transitions over time as well as a peerreviewed publication.

\section{Contact}

Carson Baughman, ASC, cbaughman@usgs.gov, (907) 7867417

\section{Recent Publication}

Baughman, C.A., Loehman, R.A., Saperstein, L., Magnes, D., and Sherriff, R., 2020, Land cover estimates for the Kenai Peninsula lowlands;1973, 2002, and 2017: U.S. Geological Survey data release, https://doi.org/10.5066/P92BGHW1.

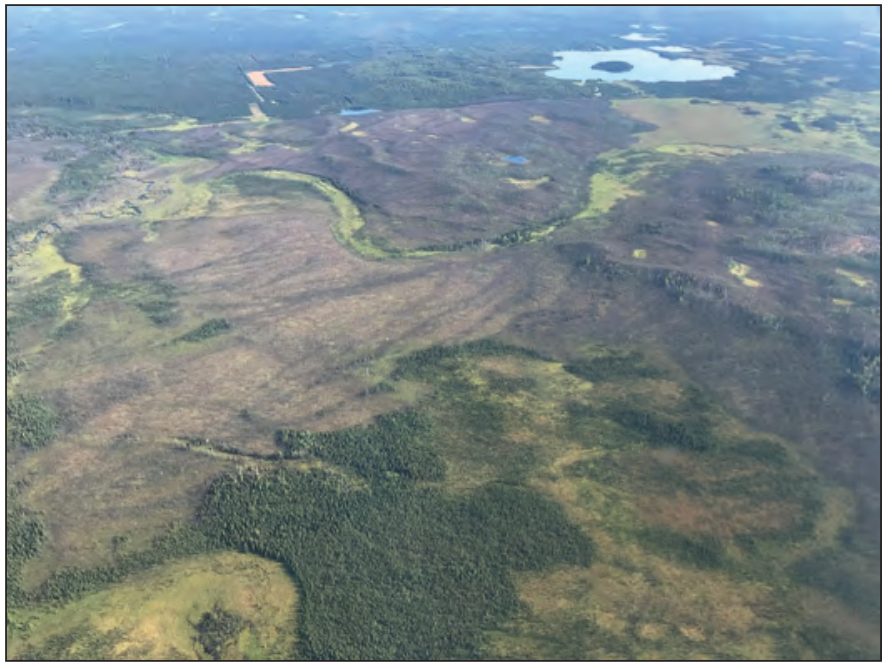

Mosaic of vegetation types and disturbance events on northern Kenai Peninsula lowlands, south-central Alaska. Browns Lake is visible in background. Photograph by Carson Baughman, U.S. Geological Survey.

\begin{tabular}{ccc}
\hline Time frame & Budget & Project partners \\
\hline $2018-20$ & $<\$ 100,000$ & U.S. Fish and Wildlife Services \\
\hline
\end{tabular}

\section{Project Links}

https://www.usgs.gov/centers/asc/science/ecosystems-edgelandscape-and-fire-ecology-forests-deserts-and-tundra?qtscience_$=\& q \mathrm{q}$-science_center_objects $=0 \#$ qt-science_center_objects

https://alaska.usgs.gov/portal/project.php?project_id=430 


\section{Habitat Dynamics—Using Satellite Remote-Sensing in Landscape-Scale Wildlife and Ecological Process Studies}
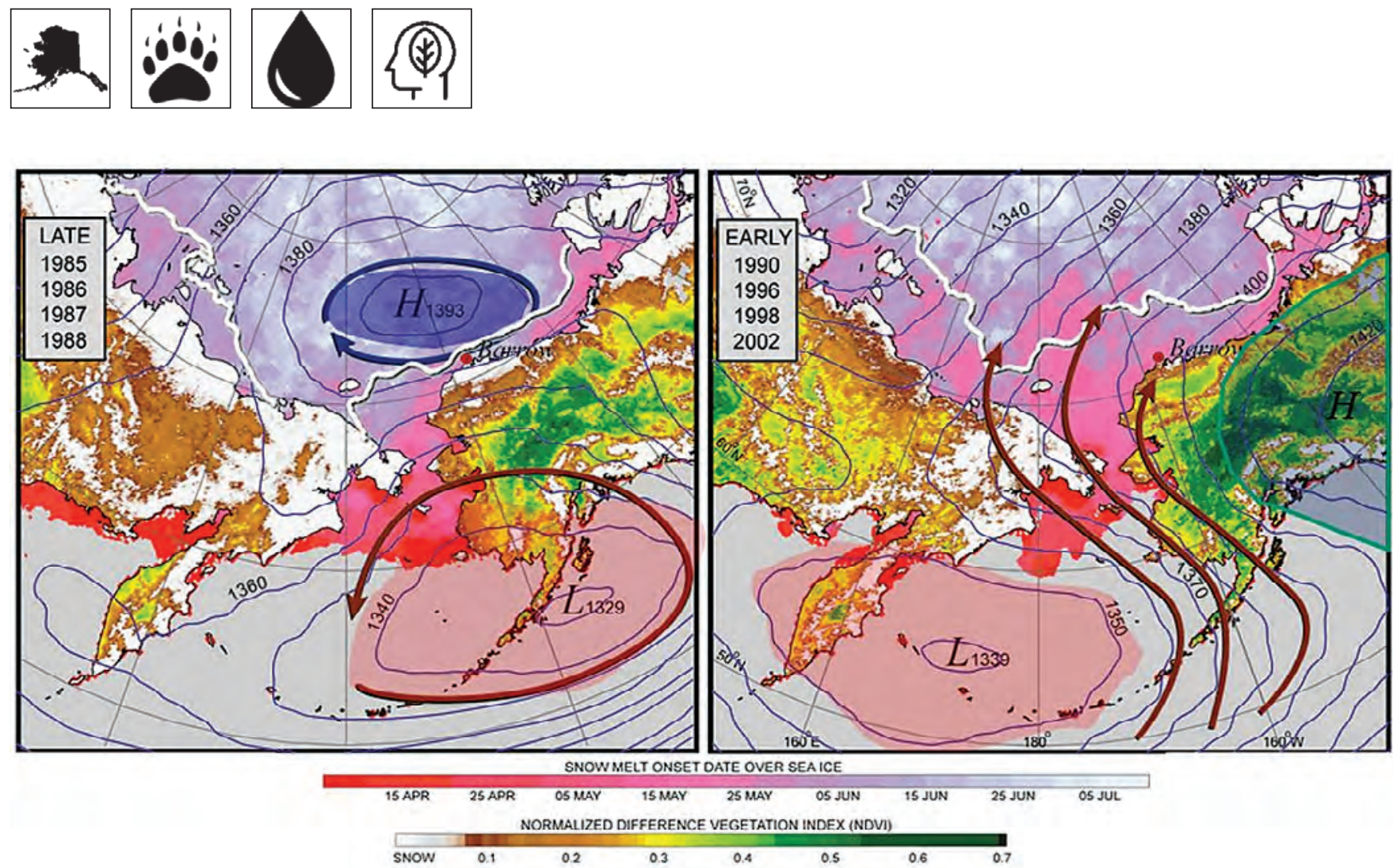

Atmospheric circulation patterns strongly influencing the timing of snowmelt and vegetation green-up in the Arctic. Source: R. Stone and David Douglas, National Oceanic and Atmospheric Administration/U.S. Geological Survey. Public domain.

The Habitat Dynamics Project examines how short- and long-term changes in the environment affect the distribution and survival of wildlife populations. Understanding linkages between the physical and biological environment is critical for

\begin{tabular}{ccc}
\hline Time frame & Budget & Project partners \\
\hline $1990-$ & $\$ 100,000-$ & U.S. Fish and Wildlife Service, North \\
ongoing & $\$ 500,000$ & Slope Borough \\
\hline
\end{tabular}
making informed management decisions. This project serves as a focal point of capability and expertise for integrating remote sensing, satellite telemetry, and GIS. Working collaboratively with other principal investigators, this project participants apply satellite and software technologies to study spatial and temporal interactions between wildlife populations and their environment. Three primary objectives are to develop (1) optimal structures for wildlife distribution databases with emphasis on satellite tracking data, (2) environmental thematic databases with emphasis on Arctic regions, and (3) GIS algorithms for integrated data analyses. 
Contact

David C. Douglas, ASC, ddouglas@usgs.gov, (907) 364-1576

\section{Recent Publications}

Ahlstrom, C.A., Bonnedahl, J., Woksepp, H., Hernandez, J., Reed, J.A., Tibbitts, T.L., Olsen, B., Douglas, D.C., and Ramey, A.M., 2019, Satellite tracking of gulls and genomic characterization of faecal bacteria reveals environmentally mediated acquisition and dispersal of antimicrobial resistant Escherichia coli on the Kenai Peninsula, Alaska: Molecular Ecology, v. 28, no. 10, p. 2531-2545, https://doi.org/10.1111/mec.15101.

Durner, G.M., Amstrup, S.C., Douglas, D.C., Fischbach, A.S., Olson, J.W., Rode, K.D., and Wilson, R.R., 2020, Catalogue of polar bear (Ursus maritimus) maternal den locations in the Beaufort and Chukchi Seas and nearby areas, 1910-2018: U.S. Geological Survey Data Series 1121, 12 p., including appendixes, https://doi.org/10.3133/ds1121. [Supersedes U.S. Geological Survey Data Series 568.]

Poessel, S.A., Uher-Koch, B.D., Pearce, J.M., Schmutz, J.A., Harrison, A.-L., Douglas, D.C., von Biela, V.R., and Katzner, T.E., 2020, Movements and habitat use of loons for assessment of conservation buffer zones in the Arctic Coastal Plain of northern Alaska: Global Ecology and Conservation, v. 22, 15 p., https://doi.org/10.1016/j.gecco.2020.e00980.

Tyson-Moore, R.B., Douglas, D.C., Nollens, H.H., Croft, L., and Wells, R.S., 2020, Post-release monitoring of a stranded and rehabilitated short-finned pilot whale (Globicephala macrorhynchus) reveals current-assisted travel: Aquatic Mammals, v. 46, no. 2, p. 200-214, https://doi.org/10.1578/AM.46.2.2020.200.

Von Duyke, A.L., Douglas, D.C., Herreman, J., and Crawford, J.A., 2020, Ringed seal (Pusa hispida) seasonal movements, diving, and haul-out behavior in the Beaufort, Chukchi, and Bering Seas (2011-2017): Ecology and Evolution, v. 10, no. 12, p. 5595-5616, https://doi.org/10.1002/ece3.6302.

U.S. Geological Survey, 2019, USGS Alaska Science Center wildlife tracking data collection: U.S. Geological Survey Alaska Science Center web page, https://doi.org/10.5066/P9VYSWEH.

\section{Project Link}

https://www.usgs.gov/centers/asc/science/habitat-dynamics 


\section{Rapid Ecosystem Changes in Tundra Biomes_-Implications for Landscapes and Humans}
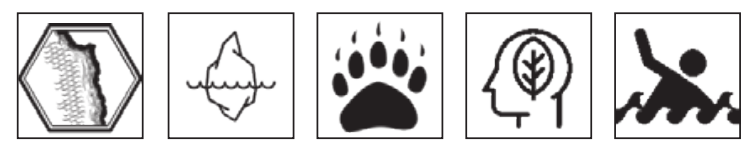

The YKD encompasses the southernmost, warmest parts of the Arctic tundra biome and is renowned for its high biological productivity and large subsistence-based human population. Recent and rapidly occurring environmental changes in this region include significant winter and spring warming, decreased sea ice extent, loss of snow cover, warming permafrost, and recurrent tundra fires, which cause significant changes in plant communities and ecosystem primary productivity. This project combines ecological ethnography with monitoring of key coastal resources and elements vulnerable to impacts from climate changes. The project was developed in response to growing awareness of rapid and potentially persistent climate change impacts to subarctic coastal ecosystems and the need to document impacts on Alaska Native villages and subsistence resources. The YKD has been underrepresented in past studies of Arctic environmental change, but the USGS, in collaboration with the FWS and others, has developed a long-term monitoring project to detect recent ecosystem changes in tundra biomes and provide our partners with information on when, where, and how future changes may occur.

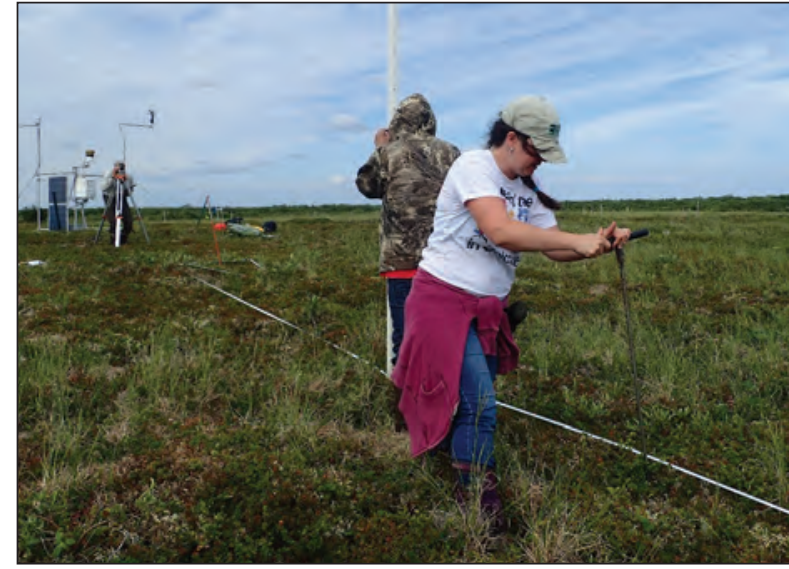

U.S. Geological Survey researchers and project partners documenting changes in permafrost, land surfaces, and vegetation communities in the Yukon-Kuskokwim Delta, western Alaska. Photograph by Rachel Loehman, U.S. Geological Survey.

\begin{tabular}{ccc}
\hline Time frame & Budget & \multicolumn{1}{c}{ Project partners } \\
\hline $2016-20$ & $\$ 100,000-\$ 500,000$ & $\begin{array}{c}\text { U.S. Fish and Wildlife Service, Bureau of Indian Affairs, Alaska Native Villages of Chevak and } \\
\text { Kotlik, Western Alaska Landscape Conservation Cooperative, U.S. Forest Service }\end{array}$ \\
\hline
\end{tabular}

\section{Contact}

Rachel Loehman, ASC, rloehman@usgs.gov, (505) 724-3664

\section{Recent Publications}

Herman-Mercer, N.M., Loehman, R.A., Toohey, R.C., and Paniyak, C., 2019, Yukon-Kuskokwim Delta berry outlook-Results from local expert surveys: U.S. Geological Survey data release, https://doi.org/10.5066/P9HDXE32.

Herman-Mercer, N.M., Loehman, R.A., Toohey, R.C., and Paniyak, C., 2020, Climate- and disturbance-driven changes in subsistence berries in coastal Alaska-Indigenous knowledge to inform ecological inference: Human Ecology, v. 48, p. 85-99, https://doi.org/10.1007/s10745-020-00138-4.

\section{Project Link}

https://www.usgs.gov/centers/gecsc/science/terrestrial-records-holocene-climate-change-fire-climate-and-humans?qt-science center_objects=0\#qt-science_center_objects 


\section{Remote Sensing Ecology Project, LandCarbon Alaska}

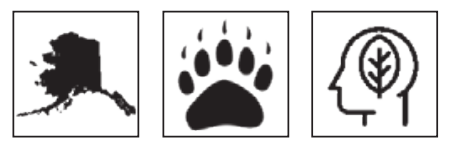

This effort was a contribution to a larger carbon assessment of Alaska (LandCarbon) that summarized terrestrial and aquatic carbon stocks and dynamics (see Wylie and others, 2016, in section, "Recent Publications," that follows). The effort was part of a larger team "special issue" of ecological applications synthesis paper. The objective was to do a data synthesis that improved our understanding of the main drivers of the spatiotemporal patterns of carbon in Alaska. The data synthesis was to address the potential carbon impacts related to the sensitivity of Alaska's ecosystems to change.

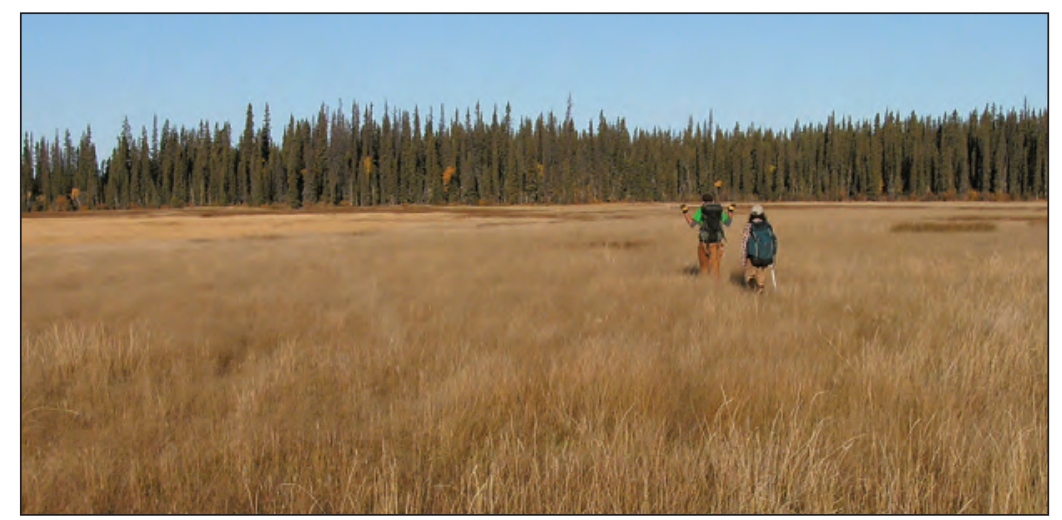

Sampling biomass, permafrost, vegetation species, and soil organic layer thickness in the Yukon Flats, interior Alaska. Photograph by Bruce Wylie, U.S. Geological Survey.

Our methods used in-place observations, remote-sensing data, and an array of modeling techniques to assess (1) climate; (2) wetland, upland, and water extents; (3) permafrost distributions; and (4) vegetation changes driven by fire. Results suggested a future reduction of near-surface (less than 1-meter) and deep (less than 5-meter) permafrost of 4-21 percent and 33-55 percent, respectively, by the end of the 21 st century. Fire extents are increasing and are expected to cause a shift from spruce to early successional deciduous forests.

\begin{tabular}{ccc}
\hline Time frame & Budget & \multicolumn{1}{c}{ Project partners } \\
\hline $2008-20$ & $\$ 1,000,000$ & $\begin{array}{c}\text { U.S. Fish and Wildlife Service, Bureau of Land Management, National Aeronautics and Space Administration } \\
\text { Arctic-Boreal Vulnerability Experiment }\end{array}$ \\
\hline
\end{tabular}

\section{Contacts}

Bruce Wylie, Earth Resources Observation and Science Center, wylie@usgs.gov, (605) 5946078

Neal Pastick, Earth Resources Observation and Science Center, njpastick@contractor.usgs.gov, (605)-594-2652

\section{Recent Publications}

Minsley, B.J., Pastick, N.J., Wylie, B.K., Brown, D.R.N., and Kass, M.A., 2017, Evidence for nonuniform permafrost degradation after fire in boreal landscapes: Journal of Geophysical Research Earth Surfaces, v. 121, no.2, p. 320-335, https://doi. org/10.1002/2015JF003781.

Pastick, N.J., Duffy, P., Genet, H., Rupp, S.T., Wylie, B.K., Johnson, K.D., Jorgenson, M.T., Bliss, N., McGuire, A.D., Jafarov, E.E., and Knight, J.F., 2017, Historical and projected trends in landscape drivers affecting carbon dynamics in Alaska: Ecological Applications, v, 27, no. 5, p. 1383-1402, https://doi.org/10.1002/eap.1538.

Pastick, N.J., Jorgenson, M.T., Goetz, S.J., Jones, B.M., Wylie, B.K., Minsley, B.J, Genet, H., Knight, J.F., Swanson, D.K., and Jorgenson, J.C., 2019, Spatiotemporal remote sensing of ecosystem change and causation across Alaska: Global Change Biology, v. 25, no. 3, p. 1171-1189, https://doi.org/10.1111/gcb.14279.

Pastick, N.J., Jorgenson, M.T., Wylie, B.K., Nield, S.J., Johnson, K.D., and Finley, A.O., 2015, Distribution of near-surface permafrost in Alaska-Estimates of present and future conditions: Remote Sensing of Environment, v. 168, p. 301-315, https://doi.org/10.1016/j.rse.2015.07.019.

Wylie, B.K., Pastick, N.J., Johnson, K.D., Bliss, N., and Genet, H., 2016, Soil carbon and permafrost estimates and susceptibility to climate change in Alaska, chap. 3 of Zhu, A., and McGuire, A.D., eds., Baseline and projected future carbon storage and greenhouse-gas fluxes in ecosystems of Alaska: U.S. Geological Survey Professional Paper 1826, p. 53-76, https://doi.org/10.3133/pp1826. 


\section{Nutrient and Contaminant Metal Fluxes to Alaskan Coastal Surface Waters}
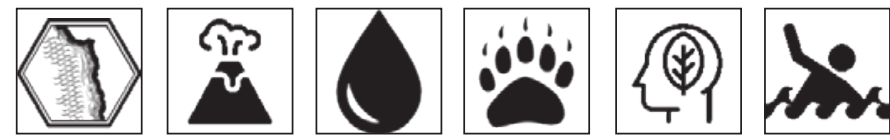

The supply of the essential nutrients, phosphorus (P), nitrogen $(\mathrm{N})$, and iron $(\mathrm{Fe})$ sets limits on various ecosystem biological processes as diverse as the burial of carbon in terrestrial wetlands and biological productivity in lakes and the ocean. This project will entail new field work sampling and analyzing dust from several remote Alaskan settings. A key objective will be to address whether Alaskan glacial flour dust, Asian dust, or both are important sources of the nutrients $\mathrm{P}, \mathrm{N}$ and Fe for these terrestrial and marine ecosystems in coastal Alaska. A long-term objective is to infer whether the rates of key processes are changing, and if so, why. Methods will include time-series filtered air sampling on Middleton Island and seasonally strategic sampling at other locations including near the mouths of the Copper and Alsek Rivers and Iliamna Lake.

\begin{tabular}{ccc}
\hline Time frame & Budget & \multicolumn{1}{c}{ Project partners } \\
\hline $2018-21$ & $\begin{array}{c}\$ 100,000- \\
\$ 500,000\end{array}$ & $\begin{array}{c}\text { University of Washington School of } \\
\text { Oceanography, Professors James } \\
\text { Murray and Randelle Bundy; Na- } \\
\text { tional Science Foundation Chemical } \\
\text { Oceanography }(\$ 291,000)\end{array}$ \\
\hline
\end{tabular}

\section{Contact}

John Crusius, ASC, jcrusius@usgs.gov, (206) 543-6978

\section{Recent Publications}

Crusius, J., Schroth, A.W., Resing, J.A., Cullen, J., and Campbell, R.W., 2017. Seasonal and spatial variabilities in northern Gulf of Alaska surface water iron concentrations driven by shelf sediment resuspension, glacial meltwater, a Yakutat eddy, and dust: Global Biogeochemical Cycles, v. 31, no. 6, p. 942-960, https//:doi.org/10.1002/2016GB005493.

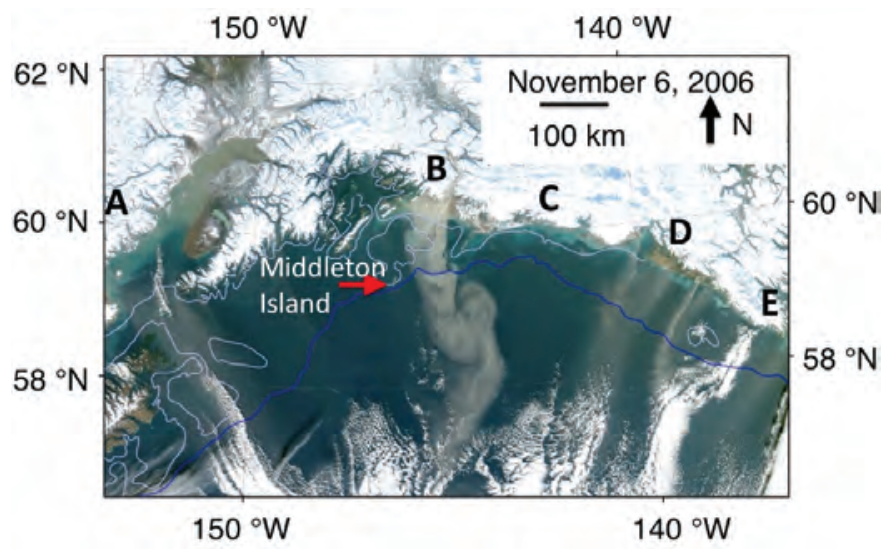

Airborne dust plumes emanating from riverbed sediments from glacier-bearing watersheds of coastal Alaska. Image also shows 100 meter bathymetric contour (white line) and the 500 meter contour (blue line). Lettered regions include locations where dust is (and is not) produced, including (A) Iliamna Lake, ( B) Copper River, $(C)$ a region where high coastal mountains prevent the winds that cause the dust, (D) Yakutat Bay/Alsek River region, and (E) Cross Sound west of Juneau. Source: John Crusius (U.S. Geological Survey) created image using data collected by the National Aeronautics and Space Administration Terra and Aqua satellites (http://modis.gsfc.nasa.gov/).

Schroth, A. W., Crusius, J., Gassó, S., Moy, C. M., Buck, N.J., Resing, J.A., and Campbell, R.W., 2017. Atmospheric deposition of glacial iron in the Gulf of Alaska impacted by the position of the Aleutian Low: Geophysical Research Letters, v. 44, no. 10, p. 5053-5061, https://doi. org/10.1002/2017GL07356.

\section{Project Link}

https://www.nsf.gov/awardsearch/showAward?AWD_ID=175 6126\&HistoricalAwards=false 


\section{Early Warning Vital Signs in Arctic Network Parklands}
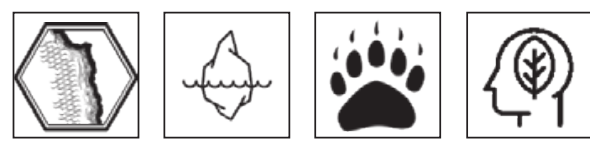

Coastal Alaska is poised for rapid industrial and environmental change. Increased vessel traffic through the Bering Strait and the Northwest Passage, oil development in the region, and a planned deepwater port to support an increased U.S. presence in the Arctic are likely to add considerable loads of $\mathrm{N}$ and other elements to the Arctic ecosystem. Arctic ecosystems are the most sensitive in North America, and total N input levels as low as 1 kilogram per hectare per year are expected to produce negative effects. The NPS aims to use the feather moss Hylocomium splendens as a cost-effective biomonitor to track the overall health of Arctic park resources and provide early warning of resource degradation. Our objectives are to establish baseline depositional patterns of elements in H. splendens in Bering Land Bridge National Preserve (BELA), which is directly adjacent to the Bering Strait, and to develop or refine prediction methods and tools relating moss tissue concentrations to critical loads and injury thresholds in BELA and Cape Krusenstern National Monument.

\section{Contact}

Danielle Cleveland, Columbia Environmental Research Center, dcleveland@usgs.gov

\begin{tabular}{ccc}
\hline Time frame & Budget & Project partners \\
\hline $2019-22$ & $\$ 100,000-$ & National Park Service $(\$ 23,000)$, Oregon State University \\
& $\$ 400,000$ & $(\$ 55,000)$, Colorado State University $(\$ 144,000)$ \\
\hline
\end{tabular}

\section{Assessing Baseline Contaminants in the 1002 Areas of the Arctic National Wildlife Refuge, Alaska}
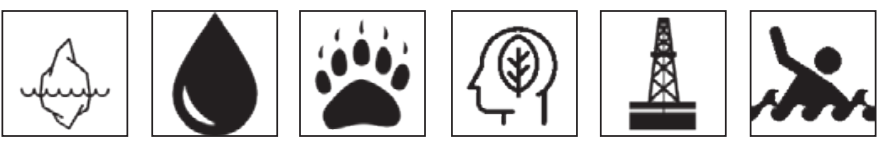

Federal agencies, including the FWS, need to assess baseline levels and types of contaminant burdens in biotic and abiotic components of the coastal plain (the 1002 Area) of the ANWR prior to oil and gas exploration and development activities. The primary objective is to use this information to assist industry in understanding, minimizing, and mitigating effects of their activities in what is currently a non-industrially impacted area. Baseline contaminant data can be used to (1) assess site-specific and area-wide development impacts; (2) address subsistence concerns of ANWR users; (3) evaluate water quality degradation; and (4), if needed, serve in the Natural Resource Damage Assessment process. Methods include the chemical analysis of water, sediments, soils, vegetation, and biota (fish) for a suite of petroleum hydrocarbons and metals.

\section{Contact}

David Alvarez, Columbia Environmental Research Center, dalvarez@usgs.gov, (573) 441-2970

\begin{tabular}{ccc}
\hline Time frame & Budget & Project partners \\
\hline $2019-22$ & $\$ 100,000-\$ 500,000$ & U.S. Fish and Wildlife Service \\
\hline
\end{tabular}

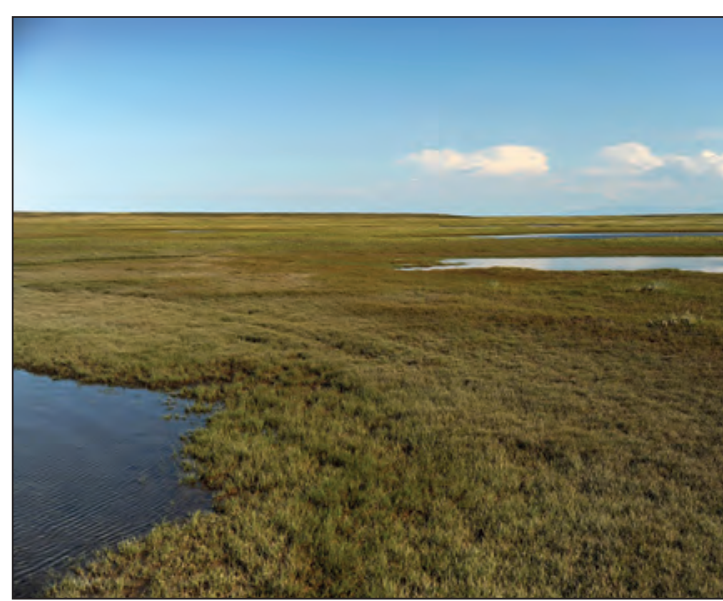

Looking southward across tundra surface and lakes on Canning River Delta near northwestern corner of Arctic National Wildlife Refuge-1002 Area, Alaska (public domain).
Feather moss Hylocomium splendens, which has and degradation of Arctic parkland natural resources. Photograph by J.W. Arms, U.S. Geological Survey. 


\section{Cross-Cutting Programs}

\section{EarthMAP Use Case Development in Alaska}
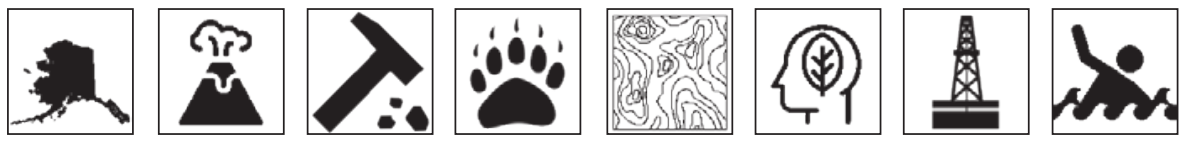

EarthMAP is the emerging conceptual mechanism that the USGS will develop over the next 10 years to facilitate and apply more fully integrated, multi-disciplinary science and technological advancements to meet decisionmaker and stakeholder needs. Use Cases_-as building blocks for EarthMAP — will identify highpriority science applications that advance the following three major components of EarthMAP: (1) data and observation integration across disciplines and agencies, (2) integrated predictive science, and (3) actionable intelligence delivery at the speed and scale of decisionmaking. Use Cases are fundamentally driven by the needs of

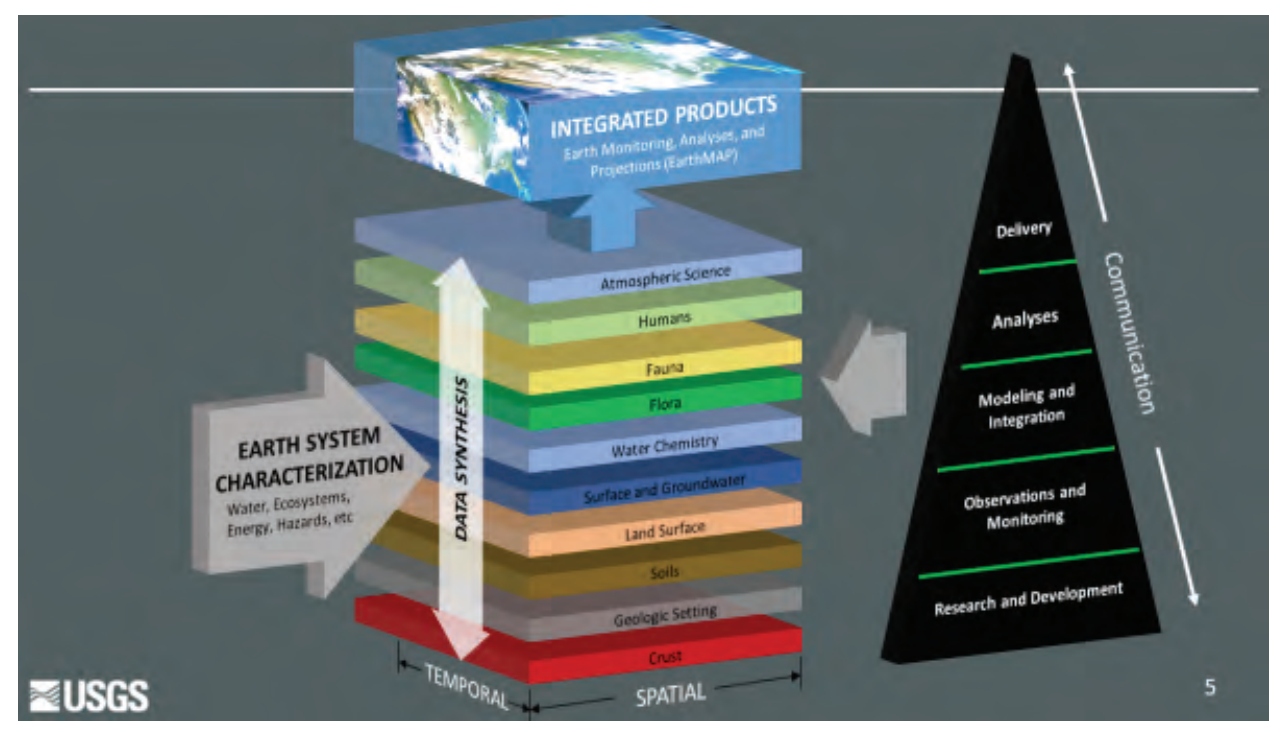

U.S. Geological Survey EarthMAP vision as developed at the Grand Challenges for Integrated U.S. Geological Survey Science workshop, February 2017. Source: U.S. Geological Survey. stakeholders and serve to identify existing and future USGS (and partner) science capacity and technological innovations that will service those needs. During this first year of EarthMAP Use Case planning, the Alaska Regional Office worked with Center Directors to develop and initiate five different Use Case prospects:

- Enhanced Delivery of Integrated Ecosystem Model Output;

- Wildlife Tracking Portal to Improve Data Documentation, Delivery and Analysis;

- Machine Learning Analysis of Near Real-Time Imagery of U.S. Volcanoes;

- Building an Integrated Coastal Hazard Assessment and Mitigation Strategy with Bering Sea Communities of Alaska; and

- Customized Arctic Map Products for State, Federal, and International Use.

\begin{tabular}{ccc}
\hline Time frame & Budget & \multicolumn{1}{c}{ Project partners } \\
\hline $2018-21$ & $\$ 1,000-\$ 500,000$ & $\begin{array}{l}\text { University of Alaska Fairbanks, State of Alaska Division of Forestry, Alaska Native communities, Bureau } \\
\text { of Land Management Alaska Fire Service, National Park Service, U.S. Fish and Wildlife Service, U.S. } \\
\text { Forest Service, Bureau of Ocean and Energy Management, National Oceanic and Atmospheric Adminis- } \\
\text { tration, Alaska Ocean Observing System, U.S. Department of State }\end{array}$ \\
\hline
\end{tabular}

Recent Publication

Jenni, K.E., and others, 2017, Grand challenges for integrated U.S. Geological Survey science-A workshop report: U.S. Geological Survey Open-File Report 2017-1076, 94 p., https://doi.org/10.3133/ofr20171076.

\section{Contact}

Dee Williams, Alaska Regional Office,dmwilliams@usgs.gov, (907) 786-7023 


\section{U.S. Geological Survey Changing Arctic Ecosystems}
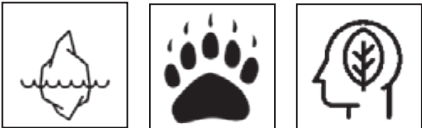

The objectives of the USGS Changing Arctic Ecosystems Initiative are to (1) quantify the responses (positive, negative, and stable) of wildlife species and their habitats to ecosystem change in the Arctic; (2) make information on these responses publicly available to inform management decisions related to development of oil and gas resources on BLM lands and on the Outer Continental Shelf managed by the BOEM; and (3) provide projections of likely future wildlife and habitat responses to inform DOI actions related to regulation or policy, Alaska Native subsistence and co-management actions, and new monitoring protocols and adaptive management strategies.

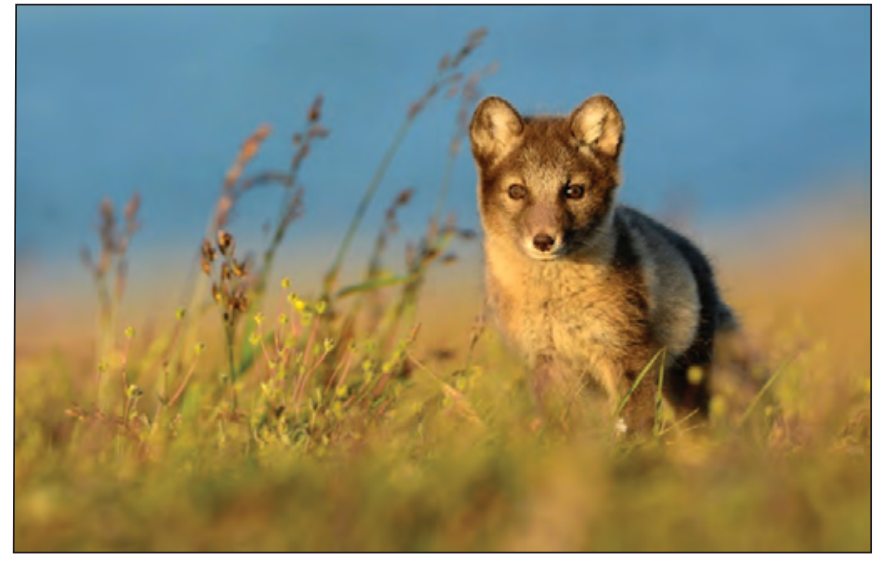

Arctic fox in the summer on the northern coast of Alaska. Photograph by Ryan Askren, U.S. Geological Survey.

\begin{tabular}{ccc}
\hline Time frame & Budget & \multicolumn{1}{c}{ Project partners } \\
\hline 2010 -ongoing $>\$ 1.000,000$ & $\begin{array}{l}\text { U.S. Fish and Wildlife Service, National Park Service, Bureau of Land Management, Bureau of } \\
\text { Ocean Energy Management, National Oceanic and Atmospheric Administration, North Slope Borough, } \\
\text { co-management councils }\end{array}$ \\
\hline
\end{tabular}

\section{Contact}

John Pearce, ASC, jpearce@usgs.gov, (907) 786-7094

\section{Recent Publications}

Amundson, C.L., Flint, P.L., Stehn, R.A., Wilson, H.M, Larned, W.W., and Fischer, J.B., 2019, Spatio-temporal population change of Arctic-breeding waterbirds on the Arctic Coastal Plain of Alaska: Avian Conservation and Ecology, v. 14, no. 1, 198 p., https://doi.org/10.5751/ACE-01383-140118.

Johnson, H.E., Golden, T.S., Adams, L.G., Gustine, D.D., and Lenart, E.A., 2020, Caribou use of habitat near energy development in Arctic Alaska: Journal of Wildlife Management, v. 84, no. 3, p. 401-412, https://doi.org/10.1002/jwmg.21809.

Laske, S. M., Rosenberger, A.E., Wipfli, M.S., and Zimmerman, C.E., 2019, Surface water connectivity controls fish food web structure and complexity across local- and meta-food webs in Arctic Coastal Plain lakes: Food Webs, v. 21, 13 p., https://doi.org/10.1016/j.fooweb.2019.e00123.

O’Donnell, J.A., Carey, M.P., Koch, J.C., Xu, X., Poulin, B.A., Walker, J., and Zimmerman, C.E., 2019, Permafrost hydrology drives the assimilation of old carbon by stream food webs in the Arctic: Ecosystems, v. 23, p. 435-453, https://doi.org/10.1007/s10021-019-00413-6.

Overduijn, K.S., Handel, C.M., and Powell, A.N., 2020, Does habitat partitioning by sympatric plovers affect nest survival?: The Auk, v. 137, no. 3, 16 p., https://doi.org/10.1093/auk/ukaa018.

Pagano, A.M., Atwood, T.C., Durner, G.M., and Williams, T.M., 2020, The seasonal energetic landscape of an apex marine carnivore, the polar bear: Ecology, v. 101, no. 3, 16 p., https://doi.org/10.1002/ecy.2959.

Poessel, S.A., Uher-Koch, B.D., Pearce, J.M., Schmutz, J.A., Harrison, A.-L., Douglas, D.C., von Biela, V.R., and Katzner, T.E., 2020, Movements and habitat use of loons for assessment of conservation buffer zones in the Arctic Coastal Plain of northern Alaska: Global Ecology and Conservation, v. 22, 15 p., https://doi.org/10.1016/j.gecco.2020.e00980.

Routti, H., and others, 2019, State of knowledge on current exposure, fate and potential health effects of contaminants in polar bears from the circumpolar Arctic: Science of the Total Environment, v. 664, p.1063-83, https://doi.org/10.1016/j.scitotenv.2019.02.030. 
Routti, H., and others, 2019, State of knowledge on current exposure, fate and potential health effects of contaminants in polar bears from the circumpolar Arctic: Science of the Total Environment, v. 664, p. 1063-1083, https://doi.org/10.1016/j.scitotenv.2019.02.030.

Uher-Koch, B.D., Wright, K.G., and Schmutz, J.A., 2019, The influence of chick production on territory retention in Arctic breeding Pacific and Yellow-billed loons: The Condor-Ornithological Applications, v. 121, no. 1, 11 p., https://doi. org/10.1093/condor/duy021.

Ware, J.V., Rode, K.D., Robbins, C.M., Leise, T., Weil, C.R., and Jansen, H.T., 2020, The clock keeps ticking: circadian rhythms of free-ranging Polar Bears: Journal of Biological Chemistry, v. 35, no 2, p.180-94, https://doi.org/10.1177/0748730419900877.

\section{Project Link}

https://www.usgs.gov/centers/asc/science/changing-arctic-ecosystems

\section{Collaboration with the Interagency Arctic Research Policy Committee}
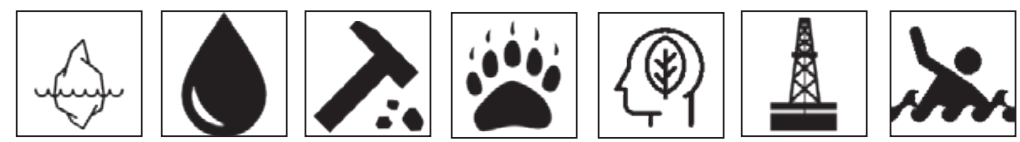

The Interagency Arctic Research Policy Committee (IARPC) was created in 1984 under the Arctic Research and Policy Act of 1984

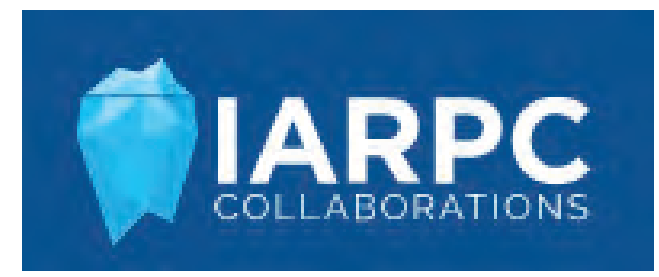

(ARPA). IARPC aims to enhance scientific research and monitoring in the

Arctic through coordination with Federal agencies and domestic and international collaborators. IARPC is required to develop and implement a 5-year research plan. The 2022-2026 Arctic Research Plan is currently being drafted with contributions from IARPC agencies and builds on input from the research community, State agencies, Tribal and non-governmental organizations, and the public. The USGS is actively engaged with the planning and development of the 2022-2026 Arctic Research Plan and USGS staff will continue to coordinate with IARPC collaborators to implement the plan when it is finalized.

\begin{tabular}{ccc}
\hline Time frame & Budget & \multicolumn{1}{c}{ Project partners } \\
\hline Ongoing & Less than & U.S. Department of Energy, U.S. Department of Homeland Security, National Oceanic and Atmospheric \\
& $\begin{array}{l}\text { Administration, Marine Mammal Commission, Smithsonian Institute, U.S. Department of Agriculture, } \\
\text { National Aeronautics and Space Administration, National Science Foundation, U.S. Environmental } \\
\text { Protection Agency, U.S. Department of the Interior, U.S. Department of Transportation, U.S. Department } \\
\text { of Defense, U.S. Department of Health and Human Services }\end{array}$ \\
& &
\end{tabular}

Contact

Elizabeth Powers, Alaska Regional Office, epowers@usgs.gov, (907) 229-5089

Project Link

https://www.iarpccollaborations.org/about.html 


\section{U.S. Geological Survey Emerging Wildlife Disease}

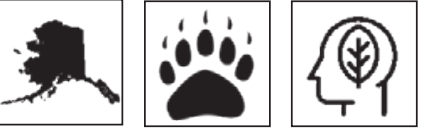

Environmental health is defined by connections between the physical environment, ecological health, and human health. Current research within USGS recognizes the importance of this integrated research philosophy, which includes study of disease and pollutants as they pertain to wildlife and humans. Because of its key geographic location and significant wildlife resources, Alaska is a critical area for future study of environmental health. Within USGS, the Emerging Wildlife Disease project is a funding opportunity for USGS scientists nationwide to address diseases of high concern to the United States. This project focuses on important wildlife disease topics such as avian influenza, bacterial and parasitic infections in wildlife, and Avian Keratin Disorder in landbirds, and responds to new topics as they arise.

\section{Contacts}

Andy Ramey, ASC, aramey@usgs.gov, (907) 786-7174 Caroline Van Hemert, ASC, cvanhemert@usgs.gov, (907) 786-7167

\section{Recent Publications}

Carter, D., Link, P., Walther, P., Ramey, A.M., Stallknecht, D.E., and Poulson, R.L., 2019, Influenza A prevalence and subtype diversity in migrating teal sampled along the United States Gulf Coast: Avian Diseases, v. 63, no. 1, p. 165-171, https://doi.org/10.1637/11850-041918-Reg.1.

Cross, P.C., Prosser, D.J., Ramey, A.M., Hanks, E.M., and Pepin, K.M., 2019, Confronting models with data-The challenges of estimating disease spillover: Philosophical Transactions of the Royal Society B, v. 374, no 1782, 10 p., https://doi.org/10.1098/rstb.2018.0435.

Harms, N. J. and Van Hemert, C.R., 2020, Wildlife parasite and pathogen life cycles in the Northwest boreal region, in Markon, C., Sesser, A.M., Rockhill, A.P., Magness, D.R., Reid, D., DeLapp, J., Burton, P., Schroff, E., and Barber, E., Drivers of landscape change in the northwest boreal region: Fairbanks, Alaska, University of Alaska Press, p. 97-104. [Also available at https://press.uchicago.edu/ucp/books/ book/distributed/D/bo45711596.html.]

Humphreys, J., Ramey, A.M., Douglas, D.C., Mullinax, J.M., Soos, C., Link, P., Walther, P., and Prosser, D.J., 2020, Waterfowl occurrence and residence time as indicators of $\mathrm{H} 5$ and $\mathrm{H} 7$ avian influenza in North American Poultry: Scientific Reports, v. 10, 16 p., https://doi.org/10.1038/s41598020-59077-1.

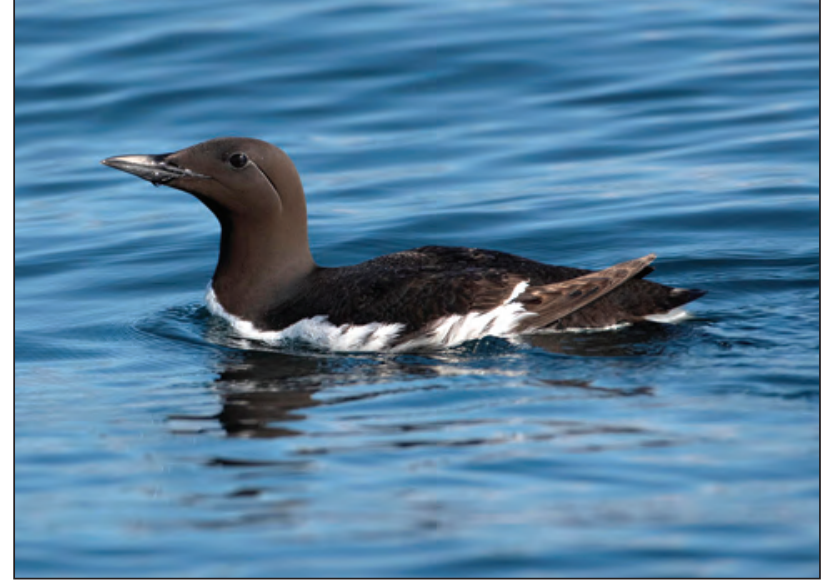

Common murre on the water near its colony in Kachemak Bay, Alaska. Photograph by Sara Schoen, U.S. Geological Survey.

\begin{tabular}{|c|c|c|}
\hline Time frame & Budget & Project partners \\
\hline $\begin{array}{c}2005- \\
\text { ongoing }\end{array}$ & $\begin{array}{c}\$ 100,000- \\
\$ 500,000\end{array}$ & $\begin{array}{l}\text { U.S. Fish and Wildlife Service, } \\
\text { Bureau of Land Management, } \\
\text { U.S. Department of Agriculture, } \\
\text { U.S. Geological Survey National } \\
\text { Wildlife Health Center, Alaska One } \\
\text { Health Group, Citizen Scientists } \\
\text { across Alaska }\end{array}$ \\
\hline
\end{tabular}

Ramey, A.M., Cleveland, C.A., Hilderbrand, G.V., Joly, K., Gustine, D.D., Mangipane, B.A., Leacock, B., Crupi, A., Hill, D.E., Dubey, J.P., and Yabsley, M.J., 2019, Exposure of Alaska brown bears (Ursus arctos) to bacterial, viral, and parasitic agents varies spatiotemporally and may be influenced by age: Journal of Wildlife Diseases, v. 55, no. 3, p. 576-588, https://doi.org/10.7589/2018-07-173.

Ramey, A.M., and Reeves, A.B., 2020, Ecology of influenza A viruses in wild birds and wetlands of Alaska: Avian Diseases, v. 64, no. 2, p. 109-122, https://doi. org/10.1637/0005-2086-64.2.109.

Ramey, A.M., Uher-Koch, B.D., Reeves, A.B., Schmutz, J.A., Poulson, R.L., and Stallknecht, D.E., 2019, Emperor geese (Anser canagicus) are exposed to a diversity of influenza A viruses, are infected during the non-breeding period, and contribute to intercontinental viral dispersal: Transboundary and Emerging Diseases, v. 66, no. 5, p. 1958-1970, https://doi.org/10.1111/tbed.13226.

Reeves, A.B., Ramey, A.M., Koch, J.C., Poulson, R.L., and Stallknecht, D.E., 2020, Field-based method for assessing duration of infectivity for influenza A viruses in the environment: Journal of Virological Methods, v. 277, https://doi. org/10.1016/j.jviromet.2020.113818. 
Smith, M.M., Van Hemert, C.R., and Handel, C.M., 2019, Evidence of Culiseta mosquitoes as vectors for Plasmodium parasites in Alaska: Journal of Vector Ecology, v. 44, no. 1, p. $68-75$, https://doi.org/10.1111/jvec.12330.

Stallknecht, D.E., and others, 2020, Limited detection of antibodies to clade 2.3.4.4 A/Goose/Guangdong/1/1996 lineage highly pathogenic $\mathrm{H} 5$ avian influenza virus in North American waterfowl: Journal of Wildlife Diseases, v. 56, no. 1, p. 47-57, https://doi.org/10.7589/2019-01-003.

Van Hemert, C.R., Meixell, B.W., Smith, M.M., and Handel, C.M., 2019, Prevalence and diversity of avian blood parasites in a resident northern passerine: Parasites and Vectors, v. 12, 16 p., https://doi.org/10.1186/s13071-019-3545-1.
Van Hemert, C.R., Schoen, S.K., Litaker, R.W., Smith, M.M., Arimitsu, M.L., Piatt, J.F., Holland, W.C., Hardison, D.R., and Pearce, J.M., 2020, Algal toxins in Alaskan seabirdsEvaluating the role of saxitoxin and domoic acid in a largescale die-off of common murres: Harmful Algae, v. 92, 9 p., https://doi.org/10.1016/j.hal.2019.101730.

\section{Project Link}

https://www.usgs.gov/centers/asc/science/wildlife-diseaseand-environmental-health-alaska

\section{U.S. Geological Survey and National Park Service Natural Resources Preservation Program}
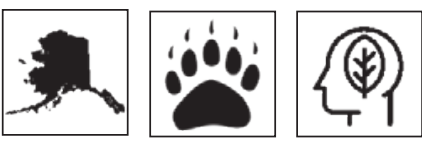

The Natural Resources Preservation Program is a nationwide science partnership that directs USGS capabilities toward priority research issues identified by the NPS. NPS priorities for these funds change annually and recent focal objectives identified by the NPS Alaska Region concerned the following topics:

- Establishing the geologic framework for NPS resource vulnerability studies and associated geohazards,

Denali National Park, Alaska;

- Tracing mercury through lake food webs in Alaska's national parks;

- Determining effects of nest predation and predator abundance on habitat quality for declining passerines breeding in a rapidly changing landscape;

- Developing baseline moss tissue concentrations in BELA;

- Evaluating Red Dog Mine spatial patterns of contaminants modelling in Cape Krusenstern; and

- Analyzing effects of glacial inputs on nearshore marine communities in a changing environment.

\begin{tabular}{ccc}
\hline Time frame & Budget & Project partners \\
\hline $2018-20$ & $\$ 100,000-\$ 499,000$ & National Park Service \\
\hline
\end{tabular}

Contact

John Pearce, ASC, jpearce@usgs.gov, (907) 786-7094

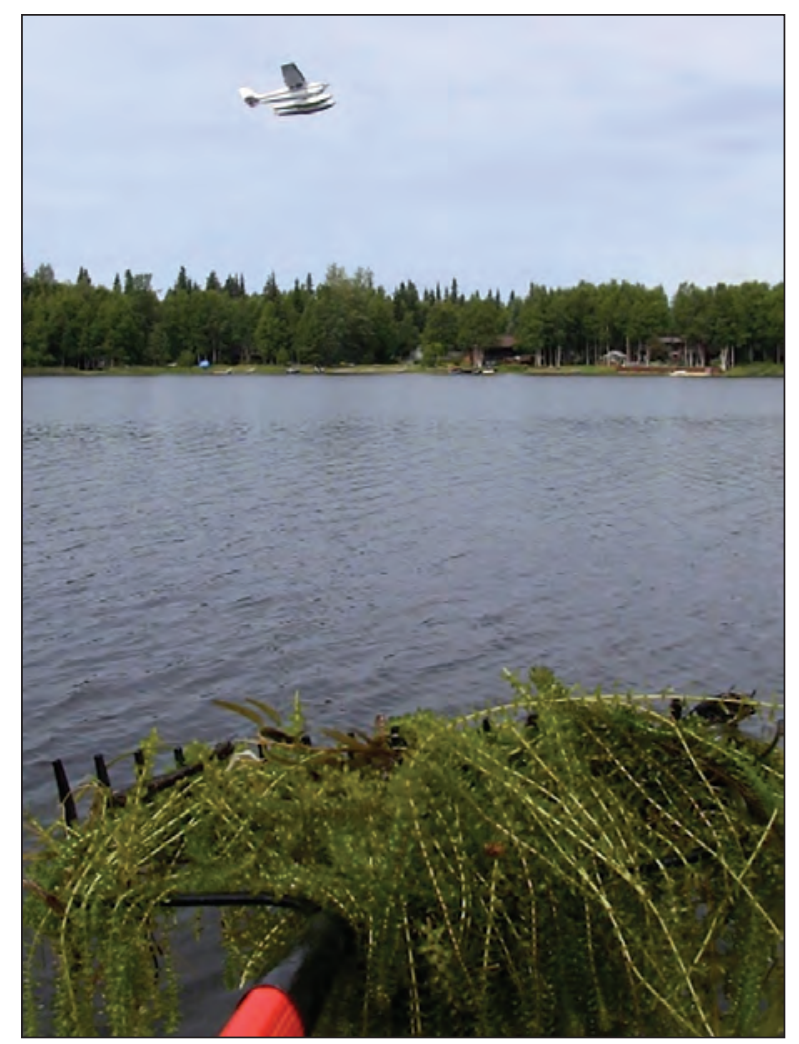

Elodea spp. on a rake in Sand Lake in Anchorage, Alaska. Photograph by Cecil F. Rich, U.S. Fish and Wildlife Service. Elodea spp. on a rake in Sand Lake in Anchorage, Alaska. Photograph by Cecil F. Rich, U.S. Fish and Wildlife Service. 


\section{U.S. Geological Survey and U.S. Fish and Wildlife Service Science Support and Quick Response Program}
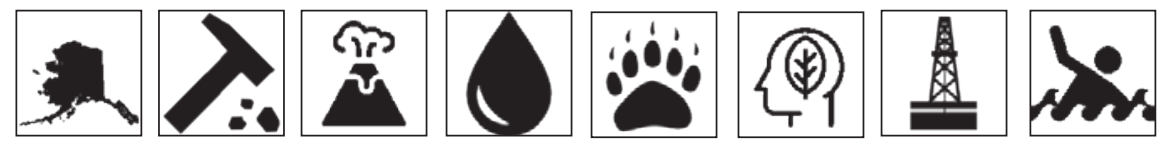

This program operates as a nationwide annual science collaboration in which USGS scientists address priority research needs identified by the FWS. FWS priorities for these funds change annually and, for the past year, the FWS Alaska Region identified a need to focus on science information delivery on topics addressing the ANWR, species of management concern, and response of wildlife to warmer temperatures. The final ASC projects recently chosen by the FWS Alaska Region for funding were as follows:

- Overwinter distribution of juvenile Dolly Varden in the Canning River, Alaska;

- Quantification of groundwater and aufeis and their contribution to surface-water availability and habitat in the ANWR, Alaska;

- Polar bear maternal den disturbance levels associated with industrial activity in the 1002 Area of the ANWR;

- Assessment of the population status of two rare taxa endemic to the central Bering Sea, Alaska-McKay's bunting and Pribilof rock sandpiper;

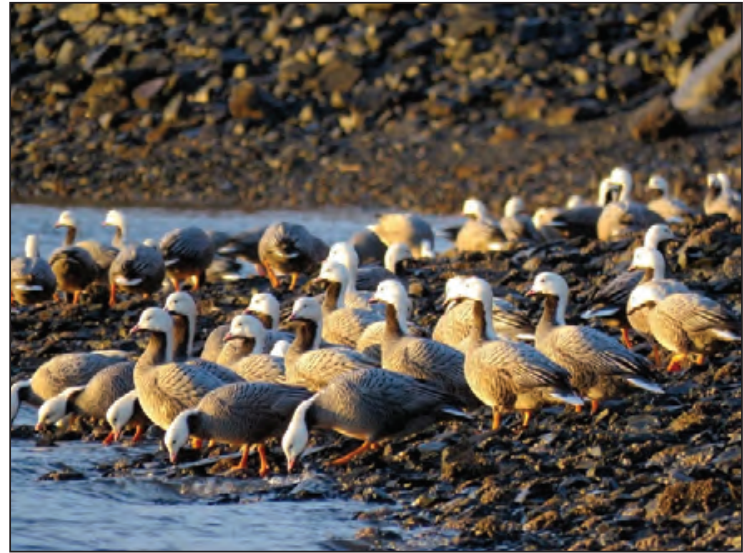

Emperor geese gathered near the shoreline on Kodiak Island, Alaska. Photograph by Brian Uher-Koch, U.S. Geological Survey.

- Status assessment of spectacled eider populations on the YKD, testing and updating predictive models;

- Investigation of hybridization between the declining gray-headed chickadee and a recent colonizer, the boreal chickadee;

- The question of whether fine-scale habitat selection minimizes thermal stress in Deshka River Chinook salmon;

- Mapping of calving and post-calving habitat quality for the Porcupine Caribou Herd under dynamic climate conditions, and assessment of the influence of habitat on neonate calf survival; and

- Distribution and abundance of breeding waterbirds in relation to habitat type on the 1002 Area of the ANWR.

\section{Contact}

John Pearce, ASC, jpearce@usgs.gov, (907) 786-7094

\begin{tabular}{ccc}
\hline Time frame & Budget & \multicolumn{1}{c}{ Project partners } \\
\hline $2018-20$ & $\$ 100,000-\$ 499,000$ & $\begin{array}{l}\text { U.S. Fish and Wildlife Service-Alaska } \\
\text { Region and Pacific Region }\end{array}$ \\
\hline
\end{tabular}

\section{Recent Publications}

Rode, K.D., Wilson, R.R., Douglas, D.C., Muhlenbruch, V., Atwood, T.C., Regehr, E.V., Richardson, E.S., Pilfold, N.W., Derocher, A.E., Durner, G.M., Stirling, I., Amstrup, S.C., St. Martin, M., Pagano, A.M., and Simac, K., 2018, Spring fasting behavior in a marine apex predator provides an index of ecosystem productivity: Global Change Biology, v. 24, p. 410-423, https://doi.org/10.1111/gcb.13933.

Tibbitts, T.L., Ruthrauff, D.R., Underwood, J.G., and Patil, V.P., 2019, Factors promoting the recolonization of Oahu, Hawaii, by bristle-thighed curlews: Global Ecology and Conservation, v. 21, 10 p., https://doi.org/10.1016/j.gecco.2019.e00785.

Ware, J.V., Rode, K.D, Bromaghin, J.F., Douglas, D.C., Wilson, R.R., Regehr, E.V., Amstrup, S.C., Durner, G., Pagano, A.M., Olson, J., Robbins, C.T., and Jansen, H.T., 2017, Habitat degradation affects the summer activity of polar bears: Oecologia, v.184, p. 87-99, https://doi.org/10.1007/s00442-017-3839-y. 


\section{Alaska Native Science and Engineering Program Partnership}
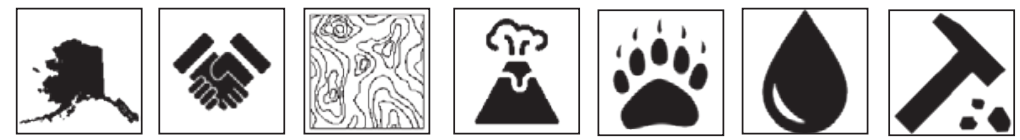

The USGS Alaska Region partners with the University of Alaska Anchorage Alaska Native Science and Engineering Program (ANSEP), a comprehensive Science, Technology, Engineering, and Math (STEM) program beginning with students in sixth grade and continuing through high school, into science and engineering undergraduate and graduate degree programs through to the Ph.D. degree. ANSEP's objective is to effect systematic change in the hiring patterns of Alaska Natives in science and engineering by placing students on a career path to leadership. USGS partners with ANSEP through a cooperative agreement, providing $\$ 50,000$ per year to support the program. Currently, USGS is in year 4 of the cooperative agreement with ANSEP, and this is the second agreement with the program. USGS also provides ANSEP students with opportunities to (1) work in a multi-disciplinary science environment that examines fish, wildlife, and lands in an ecosystem context; (2) conduct water and mineral resource assessments; (3) acquire a better understanding of natural hazards; and (4) use state-of-the-art tools, from the latest molecular genetics techniques to geospatial information technologies. USGS funds these student hires at a cost of $\$ 10,000$ per year.

\section{Contact}

Durelle Smith, Office of the Alaska Regional Director, dpsmith@usgs.gov (907) 786-7104

\section{Project Link}

https://www.ansep.net/

\begin{tabular}{ccc}
\hline Time frame & Budget & Project partners \\
\hline 2006 -ongoing & Less than $\$ 100,000$ & Alaska Native Science and Engineering Program \\
\hline
\end{tabular}

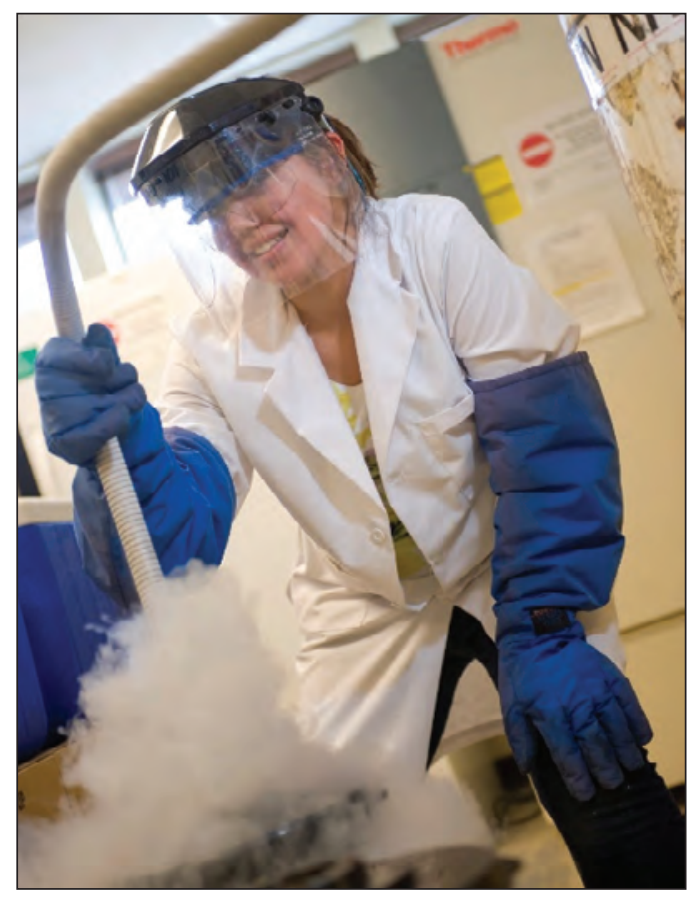

Alaska Native Science and Engineering Program student working in the U.S. Geological Survey Alaska Science Center genetics laboratory. 


\section{Ecosystems Analytics}

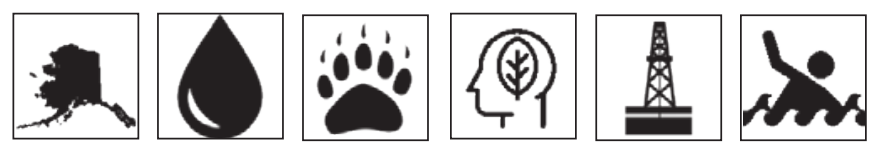

As analytical techniques have become more complex, it is increasingly difficult for content experts also to become fluent in emerging statistical methods, GIS software, or data visualization. This has created a need to solicit help from analysts to complete parts of projects or better design a novel study that can incorporate recently developed methods. The Ecosystems Analytics group at the ASC provides analytical support ranging from specific coding questions to general analysis assistance. Our goal is to save time spent analyzing data by those less familiar with certain techniques or improve inference by using novel or emerging techniques with existing data. The group helps with software coding, spatial analyses, regression, mixed-effects and hierarchical models, power analyses, sampling design, Bayesian models, web-based data applications, and web- and publication-quality figures. Projects are based on analyst ability and experience; time investment; and concordance with DOI, USGS, and Center priorities.

\begin{tabular}{ccc}
\hline Time frame & Budget & Project partners \\
\hline 2020 -ongoing & $\$ 100,000-$ & $\begin{array}{l}\text { U.S. Fish and Wildlife Service, } \\
\text { Bureau of Land Management, } \\
\text { North Slope Borough }\end{array}$ \\
\hline
\end{tabular}

\section{Contacts}

Vijay Patil,ASC, vpatil@usgs.gov, (907) 786-7178

Emily Weiser, ASC, eweiser@usgs.gov, (907) 786-7089 Jeffrey Bromaghin, ASC, jbromaghin@usgs.gov, (907) 786-7086

Rebecca Taylor, ASC, rebeccataylor@usgs.gov, (907) 786-7000

\section{Recent Publications}

Amundson, C.L., Handel, C.M., Ruthrauff, D.R., Tibbitts, T.L., and Gill, R.E., Jr., 2018, Montane-breeding bird distribution and abundance across national parks of southwestern Alaska: Journal of Fish and Wildlife Management, v. 9, no.1, p.180-207, https://doi.org/10.3996/062017JFWM-050.

Flint, P.L., Patil, V.P., Shults, B.S., and Thompson, S.J., 2020, Prioritizing habitats based on abundance and distribution of molting waterfowl, in the Teshekpuk Lake Special Area of the National Petroleum Reserve, Alaska: U.S. Geological Survey Open-File Report 2020-1034, 16 p., https://doi.org/10.3133/ofr20201034.

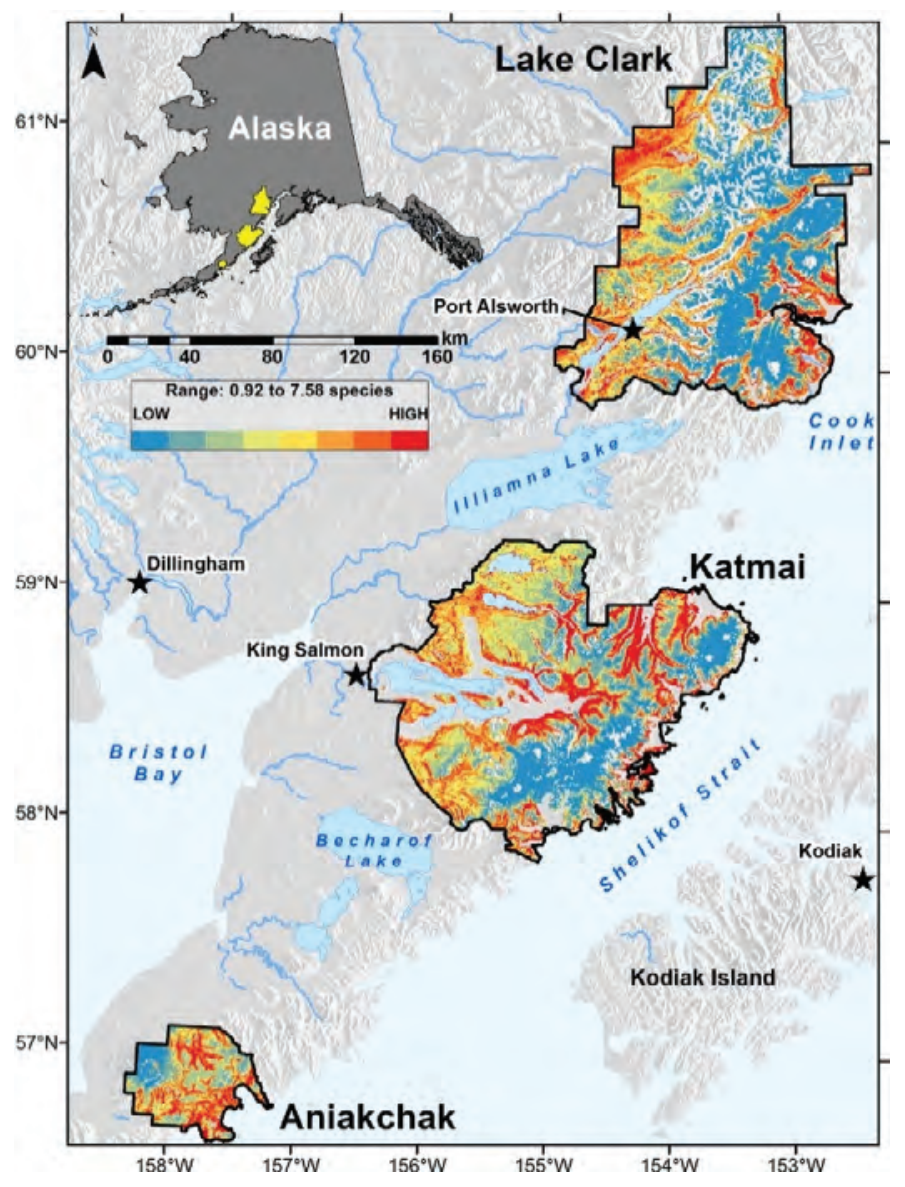

Estimated species richness of breeding birds in three Alaska national parks. From Amundson, C.L., and others, 2018 (see "Recent Publications" at the end of this section).

Pearce, J.M., and others, Visualizing populations of North American sea ducks - Maps to guide research and management planning: U.S. Geological Survey Open-File Report 2019-1142, 50 p., https://doi.org/10.3133/ofr20191142.

Wang, B., Ellefson, K.J., Granitto, M., Kelley, K.D., Karl, S.M., Case, G.N.D., Kreiner, D.C., and Amundson, C.L., 2020 , Evaluation of the analytical methods used to determine the elemental concentrations found in the stream geochemical dataset compiled for Alaska: U.S Geological Survey Open-File Report 2020-1038, 66 p., https://doi. org/10.3133/ofr20201038.

Ward, D.H., and Amundson, C.L., 2019, Monitoring annual trends in abundance of eelgrass (Zostera marina) at Izembek National Wildlife Refuge, Alaska, 2018: U.S. Geological Survey Open-File Report, 2019-1042, 8 p., https://doi. org/10.3133/ofr20191042. 
Weiser, E.L., 2020, Sample-size considerations for a study of shorebird nest survival in the 1002 Area, Arctic National Wildlife Refuge, Alaska: U.S. Geological Survey Open-File Report 2020-1066, 18 p. https://doi.org/10.3133/ofr20201066.

Weiser, E.L., and others, 2020, Annual adult survival drives trends in Arctic-breeding shorebirds but knowledge gaps in other vital rates remain: The Condor-Ornithological Applications, v. 122, no. 3, 14 p., https://doi.org/10.1093/condor/duaa026.

\section{Project Link}

https://www.usgs.gov/centers/asc/science/ecosystems-analytics

\section{Looking Forward, Looking Back-Building Resilience Today}
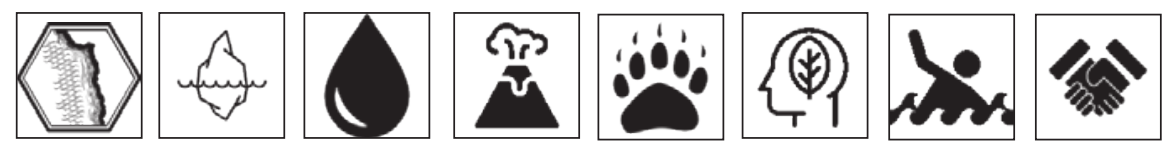

Climate change impacts are occurring faster in the Arctic than elsewhere. For rural Alaska communities, these impacts already require constant coping while preparing for future adaptation. The AKCASC, Aleutian Pribilof Islands Association, University of Alaska, and five southwestern Alaska communities developed community-specific climate information and synthesized it for use in effective risk assessments, climate adaptation plans, funding applications, and public comments. Using participatory methods, we conducted workshops and meetings to document (1) areas of climatic interest, (2) impacts on subsistence practices, and (3) local change observations change. We developed community atlases of climate changes and impacts for watersheds in areas of interest. Communities note changes in subsistence activities, travel, timing, species loss/gain, and harvest quality. Local observations include weather, climate and permafrost changes and related impacts on infrastructure, travel, food security, archaeological sites and purchasing decisions. Common themes emerge, but considerable sub-regional variation among communities exists. Paired with local observations of changes, these atlases can serve as a foundation for community adaptation efforts.

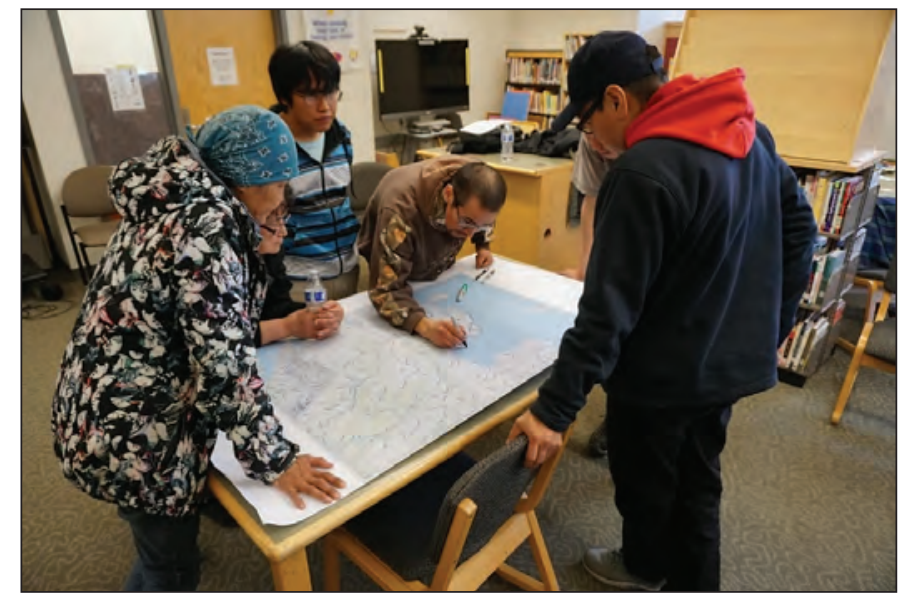

Community members defining their traditional use area, Kotlik, southwestern Alaska. Photograph by Ryan Toohey, U.S. Geological Survey.

\begin{tabular}{ccc}
\hline Time frame & Budget & \multicolumn{1}{c}{ Project partners } \\
\hline $2018-20$ & $\$ 100,000-\$ 500,000$ & $\begin{array}{c}\text { Aleutian Pribilof Islands Association, Bureau of Indian Affairs Tribal Resilience Program, Village } \\
\text { of Kotlik, Kotlik Village Council, Kotlik Yupik Corporation, Native Village of St. Michael, St. } \\
\\
\end{array}$ \\
& Michael Village Council, City of St. Michael, Native Village of Kwigillingok, Kwigillingok \\
& Village Council, Kwik Incorporated, Native Village of Kwinhagak, Quinhagak Village Council, \\
& City of Quinhagak, Qanirtuuq Incorporated, Iliamna Village Council, Village of Iliamna, \\
& University of Alaska \\
\hline
\end{tabular}

\section{Contacts}

Ryan Toohey, Alaska Climate Adaptation Science Center, rtoohey@usgs.gov, 907-865-7802

Jeremy Littell, Alaska Climate Adaptation Science Center, jlittell@usgs.gov, 907-865-7803 


\section{Developing and Applying Molecular Tools to Natural Resource Problems in Alaska}
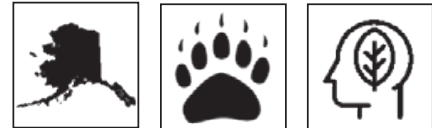

The main objectives of the ASC Molecular Ecology Laboratory are to (1) identify and fill gaps in our knowledge about species and population diagnosis, biodiversity, and health of wildlife and their habitats to inform decision-making by management agencies; and (2) provide state-of-the-art molecular science applications and protocols for USGS, DOI, and other partners. This project includes a variety of research directions and methods that inform our partners about the genetics and genomics of Alaska ecosystems. Current research objectives include (1) genetic characterization of wolf, bears, invasive species, and migratory birds for the NPS, ADF\&G, and FWS; (2) population genetics of high-latitude bird species such as the three loon species that occur in Alaska, Pacific black brant, and raptors, and use of environmental DNA (eDNA) to survey terrestrial and marine ecosystems for native and invasive species; and (3) development of genetic markers for conducting research on species of management agency interest.

\section{Contacts}

Sandra Talbot, ASC, stalbot@usgs.gov, (907) 786-7188

Sarah Sonsthagen, ASC, ssonsthagen@usgs.gov,

(907) 786-7054

\section{Project Link}

https://www.usgs.gov/labs/melab

\section{Recent Publications}

Colella, J.P., Talbot, S.L., Brochmann, C., Taylor, E.B, Hoberg, E.P., Cook, J.A., 2020, Conservation genomics in a changing Arctic: Trends in Ecology and Evolution, v. 35, no. 2, p. 149-162, https://doi.org/10.1016/j.tree.2019.09.008.

Menning, D.M., Ward, D.H., Wyllie-Echeverria, S., Sage, G.K., Gravley, M.C., Gravley, H.A., and Talbot, S.L., 2020, Are migratory waterfowl vectors of seagrass pathogens?: Ecology and Evolution, v. 10, no. 4, p. 2062-2073, https:// doi.org/10.1002/ece3.6039.

Safine, D.E., Lindberg, M.S., Martin, K., Talbot, S.L., Swem, T., Pearce, J.M., Stellrecht, N., Sage, G.K., Riddle, A.E., Fales, K.R., and Hollmén, T.E., 2020, Use of genetic markrecapture to estimate breeding site fidelity and philopatry in a threatened sea duck population, Alaska-breeding Steller's eiders: Endangered Species Research, v. 41, p. 341-360, https://doi.org/10.3354/esr01026.

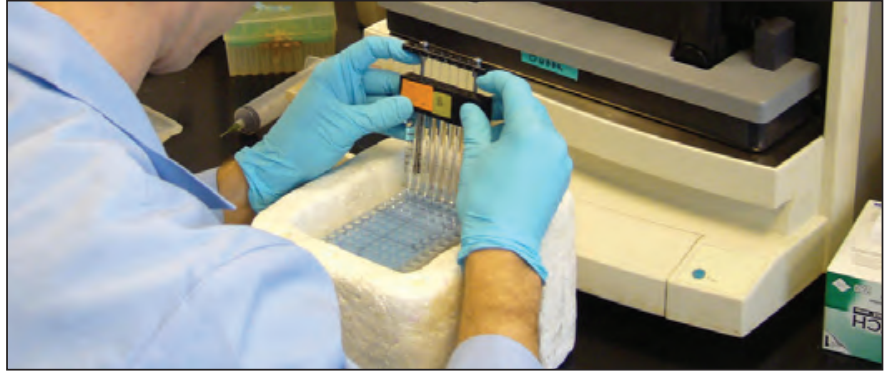

Molecular ecology laboratory procedure. Photograph by Yvette Gillies, U.S. Geological Survey.

\begin{tabular}{ccc}
\hline Time frame & Budget & \multicolumn{1}{c}{ Project partners } \\
\hline 2005-ongoing & $\$ 500,000-$ & U.S. Fish and Wildlife Service, \\
& $\$ 1,000,000$ & National Park Service, Alaska \\
& & Department of Fish and Game, \\
& Bureau of Ocean Energy \\
& & Management \\
\hline
\end{tabular}

Sonsthagen, S.A., Haughey, C.L., Sexson, M.G., Solovyeva, D., Petersen, M.R., and Powell, A.N., 2020, Temporal variation in genetic structure within the threatened spectacled eider: Conservation Genetics, v. 21, p. 175-179, https://doi. org/10.1007/s10592-019-01234-9.

Sonsthagen, S.A., Wilson, R.E., Lavretsky, P., and Talbot, S.L., 2019, Coast to coast-High genomic connectivity in North American scoters: Ecology and Evolution, v. 9, no. 12, p. 7246-7261, https://doi.org/10.1002/ece3.5297.

Wilson, R.E., Sonsthagen, S.A., DaCosta, J.M., Ely, C.R., Sorenson. M.D., and Talbot, S.L., 2019, Identification of single nucleotide polymorphisms for use in a genetic stock identification system for greater white-fronted goose (Anser albifrons) subspecies wintering in California: U.S Geological Survey Open-File Report 2019-1040, 18 p., https://doi. org/10.3133/ofr20191040.

Wilson, R.E., Sonsthagen, S.A., Smé, N., Gharrett, A.J., Majewski, A., Wedemeyer, k., Nelson, R.J., and Talbot, S.L., 2020, Mitochondrial genome diversity and population mitogenomics of Polar Cod (Boreogadus saida) and Arctic dwelling gadoids: Polar Biology, v. 43, p. 979-994, https://doi.org/10.1007/s00300-020-02703-5.

Wilson, R.E., Sonsthagen, S.A., Smé, N., Gharrett, A.J., Majewski, A., Wedemeyer, k., Nelson, R.J., and Talbot, S.L., 2020, Mitochondrial genome diversity and population mitogenomics of Polar Cod (Boreogadus saida) and Arctic dwelling gadoids: Polar Biology, v. 43, p. 979-994, https:// doi.org/10.1007/s00300-020-02703-5. 


\section{Land-Sea Linkages in the Arctic-Climate History and Past Environmental Change}
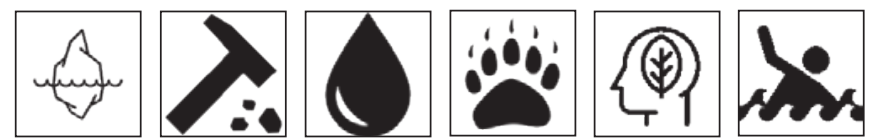

Paleoclimate records in Arctic Ocean sediments improve understanding of patterns and causes of Arctic climate change; shed light on possible future climate change and impacts of Arctic sea ice on mid-latitude weather; and help decision-makers address issues of ecosystems, endangered species, energy policy, national security, and transportation. This project investigates the changing Arctic using instrumental records and sediment cores, over short (50-year) and long (about 400,000-year) time frames. Marine sediment samples and cores will be used to document paleoceanographic changes during periods of climate variability. Pollen assemblages will be used for comparison of ocean and land-based changes. Primary research objectives include (1) evaluation pf sea ice and climate variability in the Arctic using sediment cores proxy records to support climate

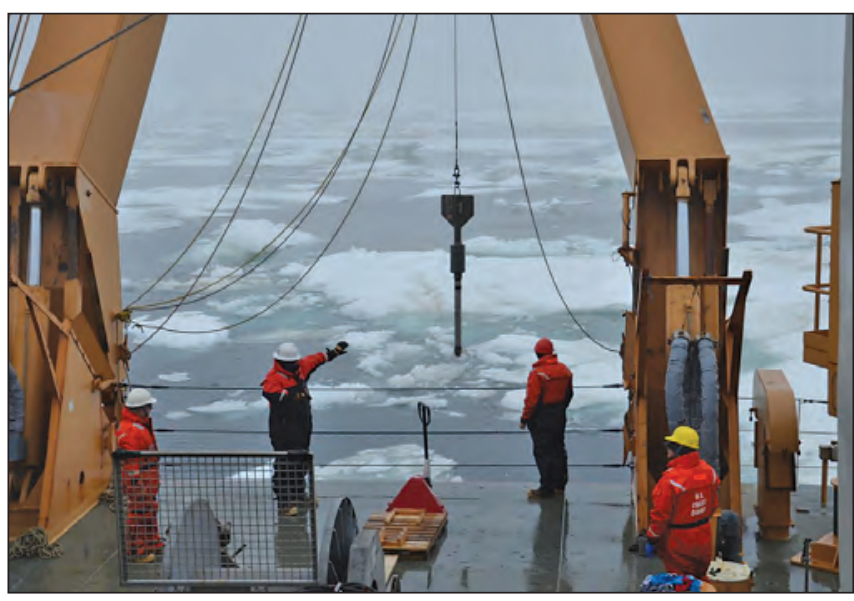

Deployment of a gravity corer aboard U.S. Coast Guard Cutter Healy during an expedition to the Chukchi Sea, northern Alaska. Photograph by Laura Gemery, U.S. Geological Survey. and sea ice models projecting future Arctic Ocean sea ice, temperature, and circulation; (2) linkage of ocean, climate, and land-cover changes in Alaska during past interglacial periods; (3) determination of baseline ocean temperature, sea ice, $\mathrm{pH}$, and marine ecosystems prior to the instrumental period of the last few decades; and (4) participation in Ryder 2019 expedition to investigate the processes by which marine outlet glaciers, including Ryder and Petermann Glaciers, drain the Greenland Ice Sheet into the ocean since the last glacial maximum.

\begin{tabular}{ccc}
\hline Time frame & Budget & Project partners \\
\hline $2019-23$ & $\$ 100,000-\$ 500,000$ & $\begin{array}{c}\text { Stockholm University; Princeton University; Columbia University; Aarhus University [Denmark]; GEO- } \\
\text { MAR, Kiel [Germany]; University of Maryland; National Ocean and Atmospheric Administration }\end{array}$ \\
\hline
\end{tabular}

\section{Contacts}

Thomas M. Cronin, Florence Bascom Geoscience Center, tcronin@usgs.gov, (703) 648-6363

Laura Gemery, Florence Bascom Geoscience Center, lgemery@usgs.gov, (703) 648-6021

\section{Recent Publications}

Cronin, T.M., Seidenstein, J., Keller, K., McDougall, K., Ruefer, A., and Gemery, L.,2019, The benthic foraminifera cassidulina from the Arctic Ocean-Application to paleoceanography and biostratigraphy: Micropaleontology, v. 65, no. 2, p. 105-125. [Also available at https://www.researchgate.net/publication/332556805_The_benthic_foraminifera_cassidulina_from_the arctic_ocean_Application_to_paleoceanography_and_biostratigraphy.]

\section{Project Link}


This page intentionally left blank. 


\section{Appendix 1. Acronyms}

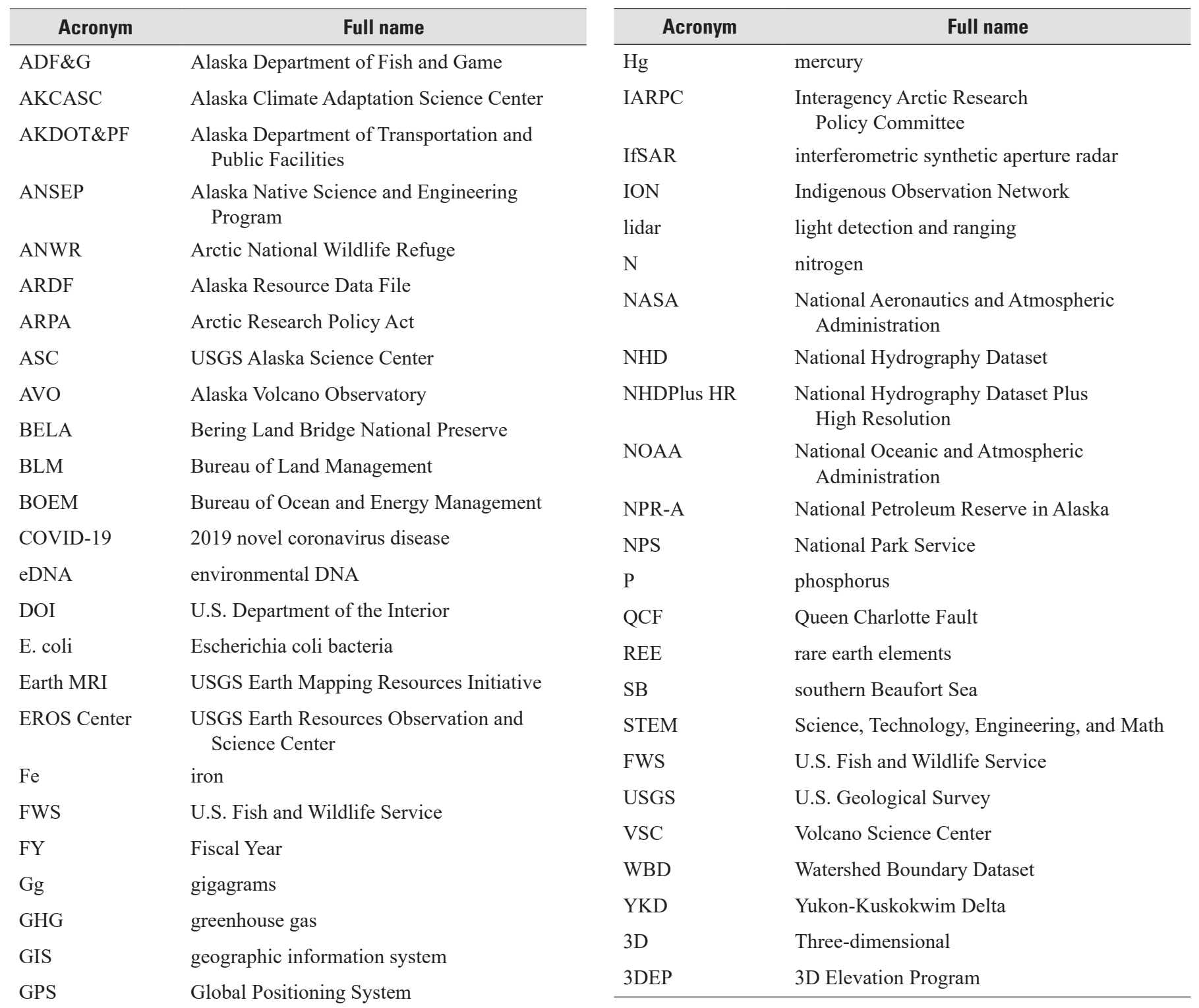

HFSE

high field strength elements 
Publishing support provided by the U.S. Geological Survey Science Publishing Network, Tacoma Publishing Service Center

For more information concerning the research in this report, contact the Regional Director, Alaska

U.S. Geological Survey

4210 University Drive

Anchorage, Alaska 99508-4560

https://www.usgs.gov/science/regions/alaska-region 
